\title{
Asthma in the 21st Century - Unexpected Applications of Ancient Treatments
}

\author{
Priyanka Pundir, Xiaofeng Wang and \\ Marianna Kulka \\ Additional information is available at the end of the chapter \\ http://dx.doi.org/10.5772/56428
}

\section{Introduction}

Asthma comes from the Greek word for "panting" and has been described as a pathological condition for centuries. It is a chronic inflammatory disorder of the airways in which many immunological cells play a role, including mast cells and eosinophils. In susceptible individuals, this inflammation causes symptoms which are usually associated with widespread variable airflow obstruction that is often reversible, either spontaneously or with treatment, and causes an associated airway hyperresponsiveness (AHR) to a variety of stimuli. The clinical features of asthma include dyspnea, wheezing and coughing.

During the last forty years there has been an increased understanding of the wide spectrum of this disease and as a result a number of effective treatments have been developed. Despite these advances, however, the mortality continues to increase and approximately 500 Canadians and 3500 Americans die each year from asthma. It remains a major cause of morbidity, as the leading cause of school absenteeism and the third leading cause of work absenteeism. The prevalence of asthma in North America has been on a constant rise over the last 25 years and it is estimated that currently over 3 million Canadians and 25 million Americans suffer from asthma. Worldwide the prevalence rates of asthma are rising on average by $50 \%$ each decade and developing a better understanding of the risk factors associated with this trend is critical. These may be broadly classified as either host genetic factors or environmental factors (Table $1)$.

One of the marked risk factors of asthma associated with the westernized lifestyle is our changing diet and/or nutritional status. It has been hypothesized that the significant change in our diet plays a dominant role in the etiology of asthma. Seaton et al. have proposed that 


\begin{tabular}{cc}
\hline Genetic Factors & Environmental Factors \\
\hline & Smoking \\
Atopy & Allergens \\
Gender & Occupational sensitizers \\
Genetic predisposition & Respiratory infections \\
Race/ethnicity & Parasitic infections \\
& Perinatal risk factors \\
& Diet and nutrition \\
\hline
\end{tabular}

Table 1. Risk factors associated with asthma

asthma prevalence has increased in UK because of an alteration in diet associated with industrialization [1]. This has lead to a substantial decline in the consumption of fresh fruits, green vegetables, fish and red meat, and as a result decrease in pulmonary antioxidant defences and an increase in susceptibility to inhaled irritants and allergens [1]. These foods are the main sources of antioxidants, substances that protect cells against the effects of free radicals generated during oxidative stress.

Oxidative stress is important in the pathophysiology of asthma [2] and development of AHR [3]. A large number of epidemiologic studies have reported the protective effects of dietary antioxidants such as micronutrients vitamin A, C, and E, polyphenol, and carotenoids against the development of asthma and decline of lung function. In a study on American children higher levels of antioxidants beta-carotene and Vitamin C, along with antioxidant trace mineral selenium is associated with a lower risk of asthma [4]. Dietary vitamin C intake is positively associated with 1 Second Forced Expiratory Volume $\left(\mathrm{FEV}_{1}\right)$ in children and adults [5-8] but less frequently with asthma or wheeze in children and adults [4,9-11]. Dietary vitamin E intake is positively associated with ventilatory function $[5,6,12]$ but negatively associated with asthma and wheeze in children [13], adult-onset wheeze [11] and the likelihood of atopic sensitization in adults [14]. Fresh fruits intake is inversely associated with wheeze [15] and chronic lung disease onset [16] and is positively associated with $\mathrm{FEV}_{1}$ [17]. Total fruit and vegetable intake is inversely related to asthma prevalence [18] but not to $\mathrm{FEV}_{1}$ [19] or airway obstruction [20]. Vegetables may protect against chronic bronchitis, asthma [21], and wheeze [22]. Moreover, dietary polyphenols intake are associated with lower disease risk with beneficial clinical outcomes attributed to both the antioxidants and anti-inflammatory properties of polyphenols [23]. Polyphenols consist of a large group of natural antioxidants extracted from plants and flavonoids comprise the most studied group.

In addition to antioxidants, intake of fats, particularly the changing composition of polyunsaturated fatty acids (PUFA) in westernized diets, has been implicated in the etiology of asthma. There has been a reduced intake of saturated fat accompanied by an increase in n-6 PUFA consumption, particularly linoleic acid and arachidonic acid. In addition, there has been a decrease in consumption of n-3 PUFA such as eicosapentaenoic acid (EPA) and docosahexaenoic acid (DHA). Thus, it has been postulated that the increased ratio of n-6:n-3 PUFA in diets of industrialized countries may also contributed to the increased asthma incidence. 
Ancient Egyptian papyrus writings contain prescriptions for asthma that include several herbs suggesting that naturally occurring bioactive compounds may been used to effectively treat asthma. This chapter summarizes the current knowledge on the effects of dietary compounds and nutrients on allergy and asthma, with a focus on the mechanisms involved, wherever possible.

\section{Pathogenesis of asthma}

Airway inflammation in asthma is a complex process involving the interactions between immunological mediators produced by inflammatory cells such as mast cells, eosinophils, basophils, neutrophils, dendritic cells and lymphocytes [24]. This inflammation leads to structural and architectural changes in the airways of asthmatic patients including collagen and fibronectin deposition, wall thickening, subepithelial fibrosis and hypertrophy, goblet and airway smooth muscle cell hyperplasia, and angiogenesis, all of which collectively contribute to the phenomenon known as airway remodeling [25].

Allergic inflammation is often classified into four phases [26]:

a. Induction of allergic reaction involving antigen uptake, processing and presentation (Figure 1),

b. Early-phase asthmatic reaction (EAR, Figure 2),

c. Late-phase asthmatic reactions (LAR, Figure 3), and

d. Chronic allergic inflammation (Figure 4)

\section{Common molecular targets used in current asthma therapy}

Inspite of the advances made in the field of asthma treatments, some patients remain less responsive to conventional therapies than others. Current treatment strategy includes the combinations of bronchodilators, particularly short or long acting $\beta_{2}$-adrenergic agonists (SABA, LABA), and inhaled and oral corticosteroids. The current approach to the management of asthma includes the addition of drugs in a stepwise fashion based on the severity of symptoms, however the stronger drugs include more severe side effects. The treatment aims to reverse airflow obstruction and reduces asthma exacerbations thus improving quality of life. However, long-term use of high dose inhaled corticosteroids therapy may lead to detrimental effects, such as cataracts [46], osteoporosis in elderly patients [47], and stunting of growth in children [48]. Moreover, the combination therapy may not modify the disease progression and are not curative.

The limited efficacy and side effects associated with conventional treatments has lead to the introduction of nutraceuticals as a "safer"alternative therapy and for those whom symptoms 


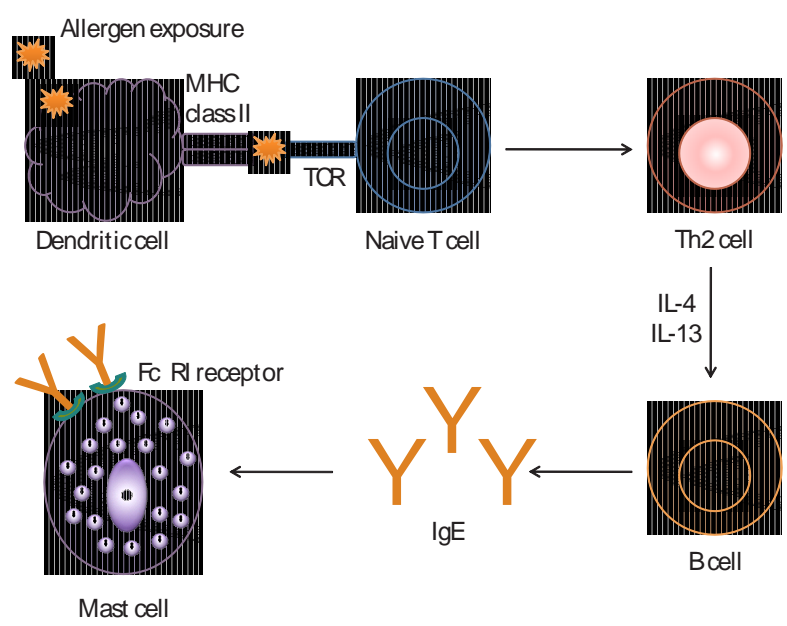

Figure 1. AHR and bronchial inflammation starts with the inhalation of an allergen. The allergen enters tissues through disrupted epithelium. It is then captured by antigen-presenting cells (APCs), usually dendritic cells (DCs), but also alveolar macrophages and B cells [27]. Allergen-loaded DCs migrate to regional lymph nodes where they present peptides to naïve T cells [28]. Presentation of processed allergen in the form of peptide fragments on MHC class II molecules to naïve T cells signals activation and clonal expansion of T cells [27]. In the presence of interleukin (IL)-4, naïve T cells acquire the characteristic of T helper 2 (Th2) cells [29]. Activated Th2 cells secrete greater amounts of IL-4 and IL-13 which triggers the isotype switch to immunoglobulin $(\mathrm{Ig})$ E synthesis $[29,30]$. IgE produced by B cells diffuses locally, enters the blood and is then distributed systematically. Allergen-specific or non-specific IgE binds to the highaffinity receptor for IgE (FcعRI) on the surface of tissue-resident mast cells and peripheral blood basophils, thereby sensitizing them to future allergen exposures [30].

are not improved with current therapies. Nutraceuticals is a very general term which encompasses many classifications of food products and derivatives that have the potential to either prevent or treat pathological conditions in humans or animals. For example, micronutrients such as vitamins and minerals and non-nutritive components of plant products such as polyphenols have some anti-inflammatory activity and have been used to supplement some foods to improve their health benefits. Table 3 summarizes some of the major nutraceuticals used to treat allergy and asthma currently.

The following sections discuss the current knowledge on the effects of nutraceuticals on inflammation associated with asthma with a focus on the cellular and molecular mechanism involved.

\subsection{Anti-mediator agents}

Anti-mediator agents are a group of drugs that antagonize the release of granule-associated preformed mediators, lipid mediators, cytokines, chemokines, and growth factors released by allergen-activated inflammatory cells. Several important groups of specific inhibitors against many of these inhibitors have been developed. 


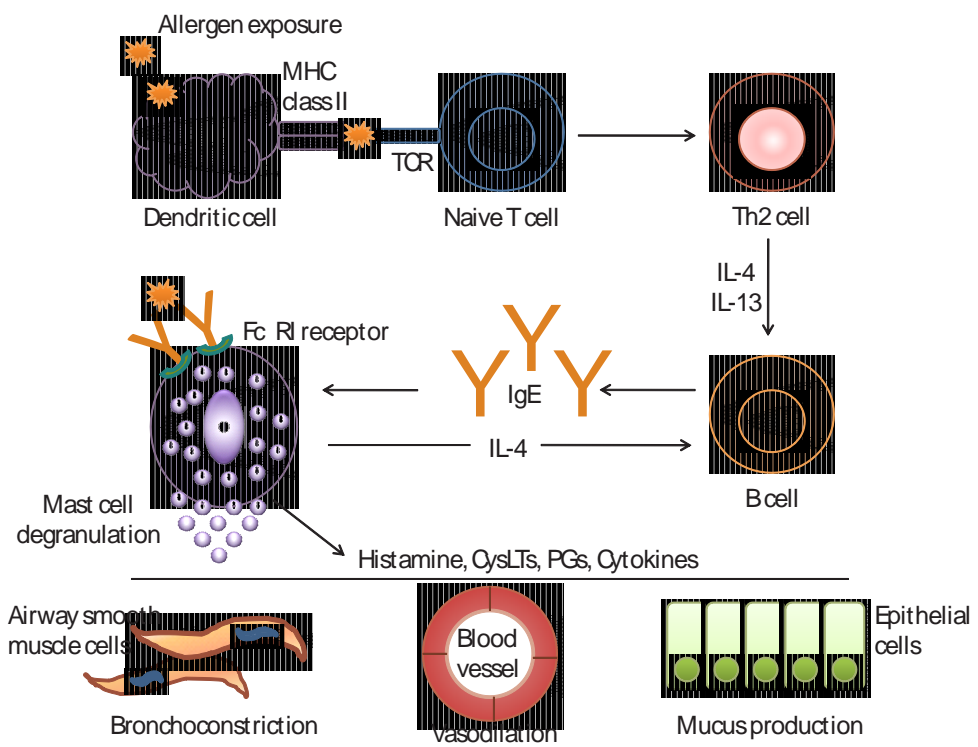

Figure 2. The EAR occurs within 30 min of allergen exposure and is principally initiated by mast cell and basophil activation [26]. Mast cells are widely distributed throughout the human respiratory tract and are found in large numbers in the walls of the alveoli and airways [31]. Asthmatics have allergen-specific IgE bound to the FcERI receptors on mast cell surface. Upon cross-linking of adjacent IgE molecules by allergen, aggregation of FceRI triggers a complex intracellular signaling process [32]. Activated mast cells release a diverse array of biologically active mediators: preformed granule-associated mediators, lipid-derived mediators, and de novo synthesized cytokines, chemokines, growth factors and other biologically active molecules (Table 2) [33]. The release of mast cell-derived mediators contributes to acute signs and symptoms associated with EAR that may range from mild rhinitis to anaphylactic shock. These mediators induce vasodilation, contraction of the bronchial smooth muscle (producing airflow obstruction and wheezing) and increased mucus secretion (exacerbating airflow obstruction in the lower airways) [26].

\subsubsection{Lipid mediator blockers}

Montelukast is a current FDA approved drug used in asthma treatment and serves a prototypical drug for Lipid Mediator Blocking class of drugs. Its mechanism of actions works through the blocking of the CysLT receptor for leukotriene $\mathrm{D}_{4}$ which reduces bronchoconstriction and inflammation. Zileuton, a related drug in the same class, is a 5-lipoxygenase inhibitor which blocks the synthesis of cysLTs and leukotriene $\mathrm{B}_{4}$. These drugs while not natural products serve as a models in the search for nutraceuticals whom may share same or related mechanism of action and therefore may prove useful in asthma management. Antagonists of the prostaglandin $\mathrm{D}_{2}$ receptors DP1 and CRTH2 reduce inflammation in a murine model of asthma, possibly by inhibiting prostaglandin synthesis $[49,50]$. Antagonist of the leukotriene $\mathrm{B}_{4}$ receptor BLT1 (R05101576) prevents airway inflammation and AHR in animal models and non-human primates [51]. Quercetin and luteolin, flavonoids found in fruits, vegetables and wine, inhibit the release of leukotrienes and PGD2 from human cultured mast cells [52]. Table 4 summarizes phytochemicals that act on pathways related to the synthesis of lipid mediators in allergic inflammation. 


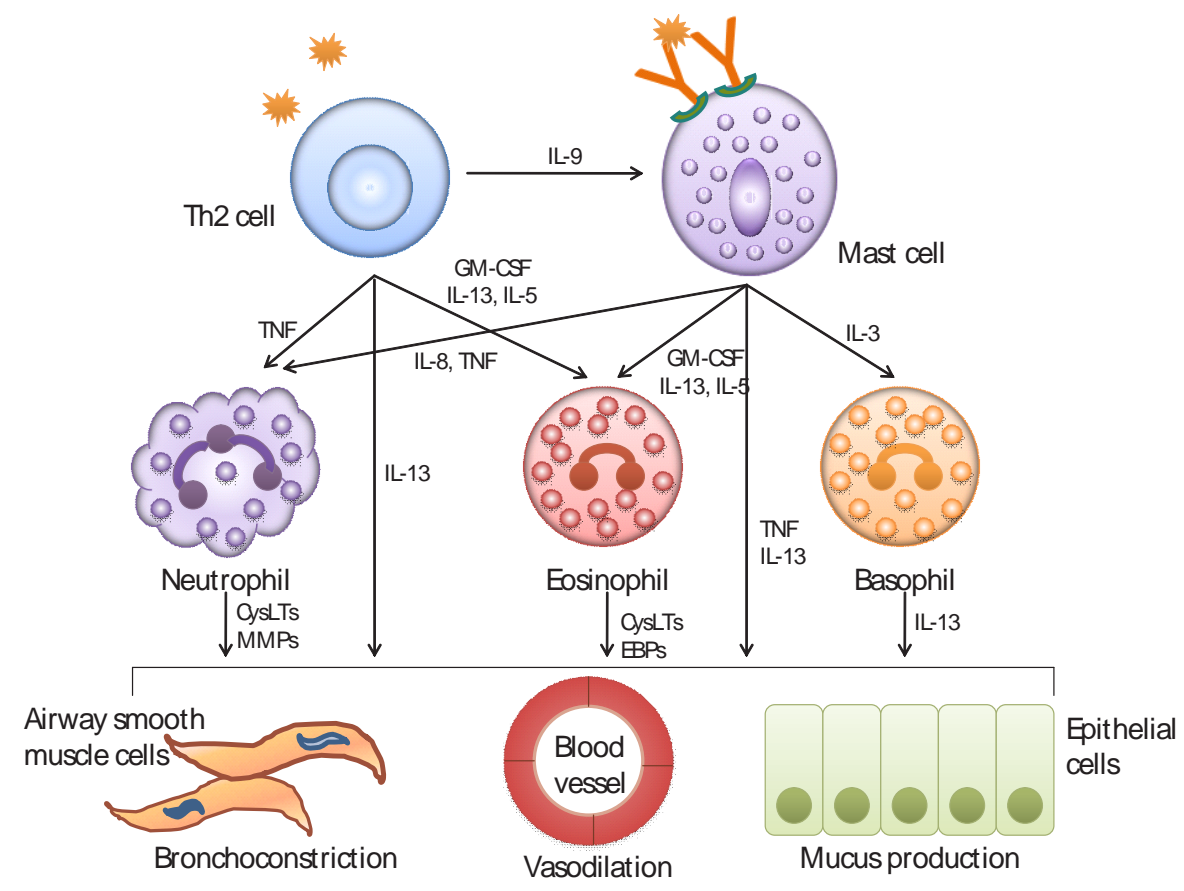

Figure 3. The LAR typically develops $2-6 \mathrm{hr}$ following allergen challenge, often peaks after 6-9 hr, and has a more severe and prolonged phase. In general, allergen activated mast cells release various de novo synthesized cytokines, chemokines and growth factors, which are released more slowly than granule-associated mediators [34]. Thus, LAR is sustained by de novo synthesized mast cell-derived mediators which recruit inflammatory cells to the airways several hours after allergen challenge. These recruited cells include effector cells, such as eosinophils, basophils, neutrophils, macrophages, T cells, and DCs [34, 35]. These inflammatory cells are activated when they reach the airway and produce a vast array of inflammatory mediators that act on specific receptors and exacerbate airway inflammation and airway remodeling. Eosinophils are the central effector cells in the LAR [36], and are present not only in the airway wall [37] but are also found in large numbers in the sputum and bronchoalveolar lavage fluid (BALF) [38]. Eosinophils are a rich source of granule basic proteins (EBP), such as major basic proteins (MBP), eosinophil cationic protein (ECP), eosinophil peroxidase (EPO), and eosinophil-derived neurotoxin (EDN), and can also generate lipid-mediators (prostaglandins and cysteinyl leukotrienes), cytokines (such as TNF, TGF- $\beta$, IL-4 and IL-13) and chemokines [39]. These eosinophil-derived products promote some of the pathophysiological hallmarks of asthma such as AHR [40]. The activation of peripheral blood neutrophils during allergen challenge results in their intravascular migration, adhesion to the endothelium, and migration to the site of inflammation and can be responsible for significant damage. Nocturnal asth$\mathrm{ma}$ is associated with high levels of neutrophils, which correlate with the severity of the disease [41]. Furthermore, in a small number of patients who died of sudden-onset asthma, the predominant cell type in the sputum is the neutrophils, not eosinophils [42]. Neutrophils also predominate more frequently in the sputum of patients with acute exacerbations of asthma, mostly associated with respiratory tract infection [43]. T cells are not only important during the induction phase, but play also a very important role during ongoing inflammation. Th2 cells and their cytokines are crucial for promoting acute hypersensitivity responses, and for maintaining the state of chronic and relapsing eosinophil-predominant inflammation that is characteristic of chronic allergic inflammation. Elevated levels of CD4 ${ }^{+} \mathrm{T}$ cells are observed in the bronchial mucosa of biopsy samples, BALF and sputum from patients with asthma [44]. In a majority of studies, T cells found in asthmatic patients express cytokines or transcription factors characteristic of Th2 cells, especially IL-4, IL-5, IL-9 and IL-13 [45]. 


\begin{tabular}{|c|c|c|}
\hline Class of Product & Examples & Biological Effects \\
\hline Preformed Mediators & Histamine, heparin & $\begin{array}{l}\text { Increase vascular permeability, } \\
\text { smooth muscle contraction }\end{array}$ \\
\hline Enzymes & $\begin{array}{l}\text { Tryptase, chymase, cathepsin G, } \\
\text { carboxypeptidase }\end{array}$ & Remodel tissue matrix \\
\hline \multirow[t]{3}{*}{ Cytokines } & IL-4, IL-13 & Stimulate Th2 cell response \\
\hline & IL-3, IL-5, GM-CSF & $\begin{array}{l}\text { Promote eosinophil production and } \\
\text { activation }\end{array}$ \\
\hline & Tumor necrosis factor (TNF) & $\begin{array}{l}\text { Promotes inflammation and cytokine } \\
\text { release by immune cells }\end{array}$ \\
\hline Chemokines & $\begin{array}{l}\text { CCL2, CCL3, CCL4, CXCL1, } \\
\text { CXCL2, CXCL3, CXCL10 }\end{array}$ & $\begin{array}{l}\text { Attract monocytes, macrophages and } \\
\text { neutrophils }\end{array}$ \\
\hline \multirow[t]{2}{*}{ Lipid Mediators } & $\begin{array}{l}\text { Prostaglandin } \mathrm{D}_{2}, \mathrm{E} 2 \\
\text { Leukotriene } \mathrm{B} 4, \mathrm{C} 4\end{array}$ & $\begin{array}{l}\text { Cause smooth muscle contraction, increase } \\
\text { vascular permeability, stimulate mucus } \\
\text { secretion }\end{array}$ \\
\hline & Platelet-activating factor & $\begin{array}{l}\text { Attracts leukocytes, amplifies production of } \\
\text { lipid mediators, activates neutrophils, } \\
\text { eosinophils and platelets }\end{array}$ \\
\hline
\end{tabular}

Table 2. Mast cell-derived proinflammatory mediators

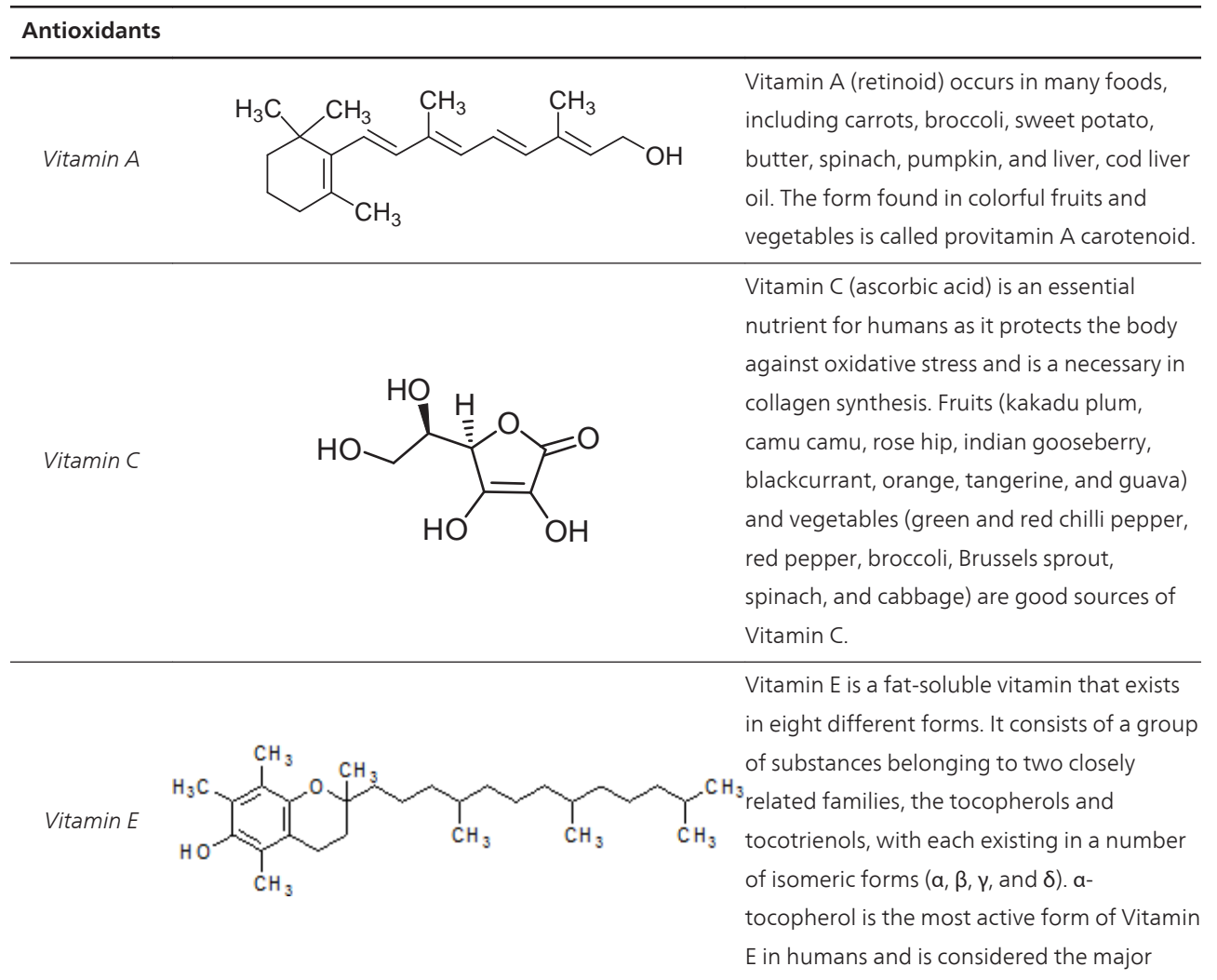




\section{Antioxidants}

membrane-bound antioxidant employed by cells. Its main antioxidant function is protection against lipid peroxidation. There is an interaction between Vitamin E and other nutrients, particularly selenium and vitamin C in the antioxidant role.

Vitamin E is found in fruits (tomato, mango, and papaya), green leafy vegetables (lettuce, spinach, turnip, and beet), nuts and nut oils (almonds and hazelnuts), vegetable oils (wheat germ oil, sunflower oil, and safflower oil), meat, and poultry.<smiles>[2H]C(/C=C1\CCC[C@H]2[C@@H]([C@@H](C)CCCC(C)(C)O)CC[C@]12C)=C1/C[C@@H](O)CCC1=[18O]</smiles><smiles>O=c1cc(-c2ccccc2)oc2ccccc12</smiles>

Flavones

Flavonoids<smiles>O=c1c(-c2ccccc2)coc2ccccc12</smiles>

Isoflavones
Flavonoids constitute the most important single group of polyphenols of low molecular weight polyphenolic secondary plant metabolites, with more than 8,000 compounds described. They are found in fruits, vegetables, nuts, seeds, stems, flowers, roots, tea, wine, and coffee and are common substances in our daily diet. Their structure is a heterocyclic hydrocarbon, chromane, and substitution of its ring $C$ in position 2 or 3 with a phenyl group (B-ring) results in flavans or isoflavans. An oxo-group in position 4 leads to flavanones and isoflavanones. The presence of a double bond between $C 2$ and C3 provides flavones and isoflavones. An additional double bond in between $\mathrm{C} 1$ and C2 makes these compounds colourful anthocyanidins. Based on their structure, flavonoids are categorized into eight groups: 


\section{Antioxidants}<smiles>O=c1c(O)c(-c2ccccc2)oc2ccccc12</smiles>

Flavonols flavans, flavanones, isoflavanones, flavones, isoflavones, anthocyanidins, chalcones, and flavonolignans (Table 11].

Resveratrol is a stilbenoid, a type of natural

Resveratrol<smiles></smiles>

Selenium e<smiles>[R]c1cc(/C=C/C(=O)Nc2ccc(O)cc2C(=O)O)ccc1O</smiles>

phenol, and a phytoalexin produced

naturally by several plants when under attack by pathogens such as bacteria or fungi. Resveratrol is found in the skin of red grapes and in other fruits. It is sold as a nutritional supplement derived primarily from Japanese knotweed.

Selenium is derived from both vegetable and animal products, particularly seafood, liver, and cereals. As a member of the sulfur family of elements, it shares several chemical properties with sulfur, including valence states and the ability to form covalent bonds with carbon. It is unique among antioxidants in that it exerts its biological effects through direct incorporation into proteins (selenoproteins) as the amino acid selenocysteine. Some selenoproteins that have been characterized as important antioxidant enzymes include GPX-1, GPX-4, thioredoxin reductase- 1 and thioredoxin reductase-2, and selenoprotein $P$. The selenium-dependent enzyme, GPX recycles glutathione, reducing lipid peroxidation by catalyzing the reduction of peroxides, including hydrogen peroxide.

Oats contain unique, low-molecular-weight, soluble phenolic compounds called avenanthramides (Avns), which are not present in other cereal grains. These compounds are antipathogens (phytoalexins), which are produced by the plant in response to exposure to pathogens 


\section{Antioxidants}

such as fungi. Avns are conjugates of a

phenylpropanoid with anthranilic acid or 5-

hydroxy anthranilic acid. More than 20

different forms of Avns are present when

extracted from oats, and the three major

forms are A, B, and C.

Table 3. Some of the dietary nutraceuticals indicated in asthma prevention.

\section{Phytochemicals}

Flavonoids

\begin{tabular}{|c|c|}
\hline $4,3^{\prime}, 5^{\prime}$-trihydroxystilbene & Inhibits Cyclooxygenase 1 \\
\hline $4,3^{\prime}$-dihydoxy- & inhibits Cyclooxygenase 1 \\
\hline \multicolumn{2}{|l|}{5 'methoxystilbene } \\
\hline 4-hydoxy-3'5'-dimethoxystilbene & Inhibits Cyclooxygenase 1 \\
\hline Acacetin & Inhibits Cyclooxygenase 1 \\
\hline Andanthoflavone & Inhibits 12-Lipoxygenase, 15-Lipoxygenase \\
\hline Apigenin & Inhibits Cyclooxygenase 2, 12-Lipoxygenase, 15-Lipoxygenase \\
\hline \multirow[t]{2}{*}{ Artonin $\mathrm{E}$} & Inhibits Cyclooxygenase 1, 5-Lipoxygenase, 12-Lipoxygenase, 15- \\
\hline & Lipoxygenase \\
\hline \multirow[t]{2}{*}{ Baicalein } & Inhibits Cyclooxygenase 1, Cyclooxygenase 2, 5-Lipoxygenase, 12 - \\
\hline & Lipoxygenase, 15-Lipoxygenase \\
\hline Bicalin & Inhibits Cyclooxygenase 1, Cyclooxygenase 2 \\
\hline Buddledin A & Inhibits Cyclooxygenase 1 \\
\hline Chrysin & Inhibits Cyclooxygenase 1, 5-Lipoxygenase \\
\hline Chrysol & Inhibits 5-Lipoxygenase \\
\hline Cirsiliol & Inhibits 5-Lipoxygenase, 12-Lipoxygenase \\
\hline Daidzein & Inhibits Cyclooxygenase 2 \\
\hline Epicatechin & Inhibits 5-Lipoxygenase \\
\hline Epigallocatechin & Inhibits 5-Lipoxygenase \\
\hline \multirow[t]{2}{*}{ Fisetin } & Inhibits Phospholipase A2, 5-Lipoxygenase, 12-Lipoxygenase, 15- \\
\hline & Lipoxygenase \\
\hline Flavone & Inhibits 5-Lipoxygenase \\
\hline Gambogenic acid & Inhibits Cyclooxygenase 2 \\
\hline Genistein & Inhibits Cyclooxygenase 2 \\
\hline
\end{tabular}

\section{Target/Function}

Inhibits Cyclooxygenase 1 


\begin{tabular}{|c|c|}
\hline Ginkgetin & Inhibits 5-Lipoxygenase \\
\hline Glycitein & Inhibits Cyclooxygenase 2 \\
\hline Isoliquiritigenin & Inhibits Cyclooxygenase 1, Cyclooxygenase 2 \\
\hline Kampferol & Inhibits Phospholipase A2 \\
\hline Kaempferol & Inhibits 5-Lipoxygenase \\
\hline Kenusanone A & Inhibits 5-Lipoxygenase \\
\hline Kisetin & Inhibits Phospholipase A2 \\
\hline Kuraridin & Inhibits Cyclooxygenase 1, 5-Lipoxygenase \\
\hline Kurarinone & Inhibits Cyclooxygenase 1, 5-Lipoxygenase \\
\hline Kuwanon C & Inhibits 5-Lipoxygenase, 12-Lipoxygenase \\
\hline Luteolin & Inhibits 5-Lipoxygenase, 15-Lipoxygenase \\
\hline Morelloflavone & Inhibits Phospholipase A2 \\
\hline Morusin & Inhibits Cyclooxygenase 1, 12-Lipoxygenase \\
\hline Mosuin & Inhibits 15-Lipoxygenase \\
\hline Myricetin & Inhibits 5-Lipoxygenase \\
\hline Narigenin & Inhibits Phospholipase A2, 5-Lipoxygenase \\
\hline Oroxidin & Inhibits 5-Lipoxygenase \\
\hline Pedalitin & Inhibits 5-Lipoxygenase \\
\hline Quercetin & $\begin{array}{l}\text { Inhibits Cyclooxygenase 1, Cyclooxygenase 2, 5-Lipoxygenase, 12- } \\
\text { Lipoxygenase }\end{array}$ \\
\hline Resveratrol & Inhibits Cyclooxygenase 1, Cyclooxygenase 2, 5-Lipoxygenase \\
\hline Rhamnetin & Inhibits 5-Lipoxygenase \\
\hline Sanggenon B & Inhibits Cyclooxygenase 1, 5-Lipoxygenase \\
\hline Sanggenon D & Inhibits 5-Lipoxygenase \\
\hline Scutellarein & Inhibits Phospholipase A2 \\
\hline Silibinin & Inhibits 5-Lipoxygenase \\
\hline Sophoflavanone A & Inhibits Cyclooxygenase 1 \\
\hline Sophoflavanone G & Inhibits Cyclooxygenase 1, 5-Lipoxygenase, 12-Lipoxygenase \\
\hline Tectorigenin & Inhibits Cyclooxygenase 2 \\
\hline Wogonin & Inhibits Cyclooxygenase 2 \\
\hline \multicolumn{2}{|l|}{ Polyphenols } \\
\hline Anisic acid & Inhibits Phospholipase A2 \\
\hline Caffeic acid & Inhibits 5-Lipoxygenase \\
\hline Catechin & Inhibits Cyclooxygenase 1, 5-Lipoxygenase \\
\hline
\end{tabular}




\begin{tabular}{|c|c|}
\hline Curcumin & $\begin{array}{l}\text { Inhibits Phospholipase A2, Cyclooxygenase 1, Cyclooxygenase 2, 5- } \\
\text { Lipoxygenase }\end{array}$ \\
\hline Diphyllin acetapioside & Inhibits 5-Lipoxygenase \\
\hline EGCG & Inhibits Cyclooxygenase 2 \\
\hline Eugenol & Inhibits 5-Lipoxygenase \\
\hline Gingerol & Inhibits 5-Lipoxygenase \\
\hline Ginkgetin & Inhibits Phospholipase A2, 5-Lipoxygenase \\
\hline Hydroxytyrosol & Inhibits 5-Lipoxygenase \\
\hline Hyperforin & Inhibits 5-Lipoxygenase \\
\hline Medicarpin & Inhibits 5-Lipoxygenase \\
\hline Ohenethyl ferulate & Inhibits Cyclooxygenase 2 \\
\hline Onosmins $\mathrm{A}$ and $\mathrm{B}$ & Inhibits 5-Lipoxygenase \\
\hline Panaxynol & Inhibits 5-Lipoxygenase \\
\hline Phenethyl ferulate & Inhibits 5-Lipoxygenase \\
\hline Quercetagetin-7-O-beta-O-glucoside & Inhibits 5-Lipoxygenase \\
\hline Rosmarinic acid & Inhibits 5-Lipoxygenase \\
\hline Rosmarinic acid methylester & Inhibits 5-Lipoxygenase \\
\hline Rosmarol & Inhibits Cyclooxygenase 20 \\
\hline n-3 PUFA & Inhibits Cyclooxygenase 2 and 5-Lipoxygenase \\
\hline
\end{tabular}

Table 4. Phytochemical inhibitors of lipid mediators

\subsubsection{Cytokines blockers}

Cytokines exhibit pleiotropy and have overlapping functions in the pathogenesis of asthma, making them a major target for new asthma therapies. Allergic inflammation is driven by an imbalance between Th1 and Th2 cytokines, favoring the Th2 arm of the immune response and inhibition of Th2 cytokines IL-4, IL-5 and IL-13 prevents asthma progression in animal models. Anti-IL-4 administration in mice prevents development of acute and chronic allergic inflammation [53], therefore, natural products that specifically target cytokines or their receptors have the potential to be effective asthma treatments.

Our current pharmacological approach include the use humanized monoclonal antibodies against specific cytokine or receptor targets. This class of drugs, known as the biologics, has been approved for use in treatment of cancer, autoimmune and inflammatory diseases. Omalizumab is a drug currently approved for the management of asthma and is antibody targeting IgE. While not specifically a cytokine blocker it functions through the same mechanism of action. These drugs while very effective carry the risk of unforeseen side effects and under current production treatment costs remain very high ranging upwards from $\$ 15,000$ to 60,000 per annum. Others examples including humanized IL-4-specific antibodies that block 
IL-4 receptor $\alpha$ that are under clinical trial [54]. Neutralizing antibodies against IL-5 (Mepolizumab and Reslizumab) and IL-5 receptor $\alpha$ (MEDI-563) remarkably inhibits IL-5 related pathways resulting in reduction of asthma exacerbations [55]. Tralokinumab, an anti-IL-13 monoclonal antibody, prevents the development of asthmatic phenotype, both in murine model as well asthmatic patients [56]. Suplatast tosilate inhibits IL-4 and IL-5 production from $\mathrm{T}$ cells and reduces AHR in asthmatic patients.

Some of the phytochemicals and potential treatments indicated against cytokines function are listed in Table 5. These products if proved to be effective, could be cost effective alternatives and being natural products have the potential to have less side effects.

\begin{tabular}{|c|c|c|}
\hline $\begin{array}{l}\text { Phytochemicals } \\
\text { Anti-oxidants }\end{array}$ & Target/Function and Effective Concentration(s) & References \\
\hline Vitamin A & $\begin{array}{l}\text { Inhibits release of Th2 cytokines IL-4, IL-5 and IL-13 in vitro as well as in } \\
\text { vivo. Suppresses production of IP-10, IL-6, TNF, GM-CSF and IFN- } \gamma \text {. }\end{array}$ & \\
\hline Vitamin C & Effect on Th1/Th2 balance controversial. & \\
\hline Vitamin $\mathrm{E}$ & $\begin{array}{l}\text { Inhibits IL-1 } \beta \text {, IL- } 6 \text { and TNF response of human monocytes in asthmatic } \\
\text { patients. Suppresses IL-4 levels in lungs of experimental allergic mice. }\end{array}$ & \\
\hline \multicolumn{3}{|l|}{ Flavonoids } \\
\hline Apigenin & $\begin{array}{l}\text { Reduces airway inflammation by down-regulating Th2 cytokines IL-4 } \\
\text { and IL-13. Suppresses the expression of Th2 cytokines (IL-4, IL-13 and } \\
\text { IL-5) in human basophils. Inhibits production of TNF, IL-6 and GM-CSF } \\
\text { in HMC-1 cells. }\end{array}$ & {$[57,58]$} \\
\hline Baicalein & $\begin{array}{l}\text { Decreases inflammatory cytokines such as TNF and IL- } 6 \text { in allergic } \\
\text { inflammation. Inhibits production of IL- } 6 \text { in activated human mast } \\
\text { cells, and GM-CSF from human cultured mast cells. }\end{array}$ & {$[52,59]$} \\
\hline Bicalin & $\begin{array}{l}\text { Reduces TNF and IL- } 6 \text { levels in plasma and BALF in cigarette smoke- } \\
\text { induced COPD rat model. }\end{array}$ & {$[60]$} \\
\hline Chrysin & $\begin{array}{l}\text { Downregulates IL-4 and IL-13 expression and production in allergen- } \\
\text { sensitized mice. Inhibits TNF, IL-1 } \beta, \text { IL-4 and IL-6 expression in RBL-2H3 } \\
\text { and HMC- } 1 \text { cells. }\end{array}$ & {$[61]$} \\
\hline Chrysol & Inhibits IL-4 production in antigen-stimulated RBL-2H3 cells. & {$[62]$} \\
\hline Daidzein & Mast cell stabilizer; inhibits Th2 cytokines production. & \\
\hline Fisetin & $\begin{array}{l}\text { Inhibits IL-13 production in RBL-2H3 cells, and TNF, IL-6, IL-4 and IL-1 } \\
\text { production in HMC-1 cells. Suppresses the expression of Th2 cytokines } \\
\text { (IL-4, IL-13 and IL-5)in human basophils. Attenuates LPS-induced TNF, } \\
\text { IL-6 and IL-10 release in leukocytes of patients with COPD. }\end{array}$ & {$[57,63-65]$} \\
\hline Genistein & Inhibits TNF production in PBMCs from asthmatic patients. & \\
\hline Ginkgetin & Inhibits TNF expression in activated macrophages. & \\
\hline
\end{tabular}




\section{Phytochemicals}

Anti-oxidants

Isoliquiritigenin

Kaempferol

macrophages. Inhibits IgE-mediated TNF and IL-6 release in hCBMCs.

\begin{tabular}{ll}
\hline Kuraridin & $\begin{array}{l}\text { Suppresses expression of TNF and IL-1 } \beta \text { in LPS-stimulated } \\
\text { macrophages }(40 \mu \mathrm{M}) .\end{array}$ \\
\hline Kurarinone & $\begin{array}{l}\text { Suppresses expression of TNF and IL-1 } \beta \text { in LPS-stimulated } \\
\text { macrophages }(40 \mu \mathrm{M}) .\end{array}$ \\
\hline
\end{tabular}

Reduces the levels of TNF and IL-1 $\beta$ in LPS-stimulated macrophages (8

\& $16 \mu \mathrm{M})$. Inhibits induction of TNF, IL-6 and GM-CSF in HMC-1 cells

(10 \& $50 \mu \mathrm{M}$ ). Inhibits Th2 cytokines (IL-4, IL-5 and IL-13) expression in murine asthma model ( $50 \& 100 \mathrm{mg} / \mathrm{kg}$ body wt.). Inhibits myelin

Luteolin basic protein-induced IL-6, TGF- $\beta 1$, and TNF release in hCBMCs (10 \& $100 \mu \mathrm{M})$. Decreases TNF $\left(I C_{50} 7.9 \pm 4.6 \mu \mathrm{M}\right)$ and IL-1 $\beta\left(\mathrm{C}_{50} 5.1 \pm 0.4 \mu \mathrm{M}\right)$ in PBMCs. Reduces IL-4 and IL-5 levels in BALF of murine asthma model $\left(0.1 \mathrm{mg} / \mathrm{kg}\right.$ body wt.). Inhibits antigen-IgE-mediated TNF $\left(\mathrm{IC}_{50}\right.$ $5.8 \mu \mathrm{M})$ and IL-4 (IC $50.7 \mu \mathrm{M})$ production in RBL-2H3 cells.

\begin{tabular}{ll}
\hline Morin & Inhibits IgE-mediated TNF and IL-6 release in hCBMCs (10 \& $100 \mu \mathrm{M})$. \\
& Inhibits TNF secretion in LPS-activated macrophages.
\end{tabular}
Inhibits TNF $(30 \mu \mathrm{M})$ and IL-6 (30 $\mu \mathrm{M})$ production in HMC-1 cells. $\begin{array}{ll}\text { Myricetin } & \text { Inhibits IgE-mediated TNF }(10 \& 100 \mu \mathrm{M}) \text { and IL-6 }(1,10 \& 100 \mu \mathrm{M}) \\ & \text { release from hCBMCs. }\end{array}$

\begin{tabular}{|c|c|c|}
\hline \multirow{6}{*}{ Naringenin } & Suppresses Th2 cytokines production from CD4 T cells $(0.8 \mathrm{mg} / \mathrm{kg}$ & \multirow{6}{*}{ [77-79] } \\
\hline & body wt.). Reduces IL-4 (25, 50 \& $100 \mathrm{mg} / \mathrm{kg}$ body wt.) and IL-13 (50 \& & \\
\hline & 100 mg/kg body wt.) levels in BALF of murine asthma model. & \\
\hline & Suppresses LPS-induced IL-1 $\beta(10,25 \& 50 \mu \mathrm{g} / \mathrm{mL}), \mathrm{IL}-6(5,10,25 \& 50$ & \\
\hline & $\mu \mathrm{g} / \mathrm{mL})$, and TNF ( $25 \& 50 \mu \mathrm{g} / \mathrm{mL})$ production in macrophages and & \\
\hline & human whole-blood samples. & \\
\hline Pedalitin & $\begin{array}{l}\text { Inhibits TNF and IL-12 production in LPS-activated macrophages ( } 40 \\
\mu \mathrm{M} \text { ). }\end{array}$ & {$[80]$} \\
\hline \multirow{2}{*}{ Quercetin } & Inhibits IgE-mediated TNF (10 \& $100 \mu \mathrm{M})$ and IL-6 $(1,10 \& 100 \mu \mathrm{M})$ & \multirow{2}{*}{ [75] } \\
\hline & release from hCBMCs. & \\
\hline \multirow{5}{*}{ Resveratrol } & Inhibits increase in Th2 cytokines (IL-4 and IL-5) in plasma and BALF in & \multirow{5}{*}[68,81-86]{} \\
\hline & asthmatic mouse model (30 mg/kg body wt.). Inhibits TNF induced & \\
\hline & GM-CSF and VEGF release in HASM cells. Inhibits PMA- and A23187- & \\
\hline & induced TNF and IL-6 release in HMC-1 cells. Decreases production of & \\
\hline & IL-1 $\beta$ in lung tissue of mice with LPS-induced acute lung injury (1 & \\
\hline
\end{tabular}




\section{Phytochemicals}

Anti-oxidants

\begin{tabular}{|c|c|c|}
\hline & $\begin{array}{l}\text { mg/kg body wt.). Attenuates C } 5 \text { a-induced TNF, IL-1 } \beta \text { and IL-6 } \\
\text { production in mouse model ( } 10 \mathrm{mg} / \mathrm{kg} \text { body } w \mathrm{t} .) \text {. }\end{array}$ & \\
\hline Scutellarein & $\begin{array}{l}\text { Inhibits TNF and IL-12 production in LPS-activated macrophages ( } 40 \\
\mu \mathrm{M}) \text {. }\end{array}$ & {$[80]$} \\
\hline Silibinin & $\begin{array}{l}\text { Polarizes Th1/Th2 balance towards Th1 by increasing IFN- } \text { ( } 200 \& 400 \\
\mathrm{mg} / \mathrm{kg} \text { body wt.) and decreasing IL-4 levels ( } 200 \& 400 \mathrm{mg} / \mathrm{kg} \text { body } \\
\text { wt.) in asthmatic mouse model. }\end{array}$ & [87] \\
\hline \multicolumn{3}{|l|}{ Polyphenols } \\
\hline Caffeic acid & $\begin{array}{l}\text { Inhibits increase in TNF and Th2 cytokines (IL-4 and IL-5) in BALF in } \\
\text { asthmatic mouse model ( } 10 \mathrm{mg} / \mathrm{kg} \text { body wt. IP). Inhibits IL-10 } \\
\text { expression in allergic patients' DCs ( } 10 \mu \mathrm{M}) \text {. Suppresses TNF and IL-6 } \\
\text { levels in asthmatic patients ( } 13 \% \text { solution). }\end{array}$ & [88-90] \\
\hline Curcumin & $\begin{array}{l}\text { Attenuates the expression of IL-4 and IL-5 in BALF in asthmatic mouse } \\
\text { model ( } 20 \mathrm{mg} / \mathrm{kg} \text { body wt.). Inhibits release of IL-10, TNF and IL-1 } 13 \text { in } \\
\text { HDM-activated eosinophils and bronchial epithelial cells }(10 \mu \mathrm{M}) \text {. } \\
\text { Inhibits IL-5, GM-CSF and IL-4 production in lymphocytes from } \\
\text { bronchial asthmatics ( } 10 \mu \mathrm{M}) \text {. Inhibits TNF secretion in activated } \\
\text { HMC-1 cells ( } 10 \& 100 \mu \mathrm{M} / \mathrm{L}) \text {. Inhibits tryptase-induced IL-6 release in } \\
\text { eosinophils }(25 \mu \mathrm{M}) \text {. }\end{array}$ & [91-95] \\
\hline EGCG & $\begin{array}{l}\text { Reduces TNF in BALF in asthmatic guinea pigs ( } 25 \mathrm{mg} / \mathrm{kg} \text { body wt. SC). } \\
\text { Inhibits TNF and IL- } 6 \text { production in HMC-1 cells }(100 \mu \mathrm{M}) \text {. Attenuates } \\
\text { production of TNF in lungs of mice with LPS-induced acute lung injury } \\
(10 \mathrm{mg} / \mathrm{kg} \text { body wt. IP). }\end{array}$ & [96-99] \\
\hline Eugenol & Inhibits IL-1 $\beta$, TNF and IL- 6 release in macrophages. & {$[100,101]$} \\
\hline Gallic acid & Inhibits TNF and IL-6 in HMC- 1 cells $(10 \mu \mathrm{M})$. & [102] \\
\hline Gingerol & Inhibits IL-1 $\beta$ and IL-12 release in peritoneal macrophages $100 \mathrm{ng} / \mathrm{mL}$ ) & [103] \\
\hline Hydroxytyrosol & $\begin{array}{l}\text { Inhibits LPS-induced TNF production in THP-1 cells }(25,50 \& 100 \mu \mathrm{M}) \text {. } \\
\text { Reduces TNF levels in LPS-treated mice. }\end{array}$ & {$[104,105]$} \\
\hline Rosmarinic acid & $\begin{array}{l}\text { Reduces IL-4, IL-5 and IL-13 expression in lung of HDM-sensitized } \\
\text { asthmatic mouse model ( } 1.5 \mathrm{mg} / \text { day PO). Attenuates IL-1 } \beta \text {, IL-6, and } \\
\text { TNF increase in spleen and nasal mucosa of asthmatic mouse model ( } 4 \\
\mathrm{mg} / \mathrm{kg} \text { body wt.). Inhibits IL-4 and IFN- } \gamma \text { release from CD4+ T cells ( } 1 \text { \& } \\
5 \mu \mathrm{M}) \text {. Inhibits diesel exhaust particles-induced IL-1 } \beta \text { expression in } \\
\text { mice lung ( } 4.6 \mu \mathrm{g} / \mathrm{kg} \text { body wt.). }\end{array}$ & {$[106-110]$} \\
\hline
\end{tabular}

\section{Terpenes}

Celastrol
Target/Function and Effective Concentration(s)

References 


\begin{tabular}{lll}
\hline $\begin{array}{l}\text { Phytochemicals } \\
\text { Anti-oxidants }\end{array}$ & Target/Function and Effective Concentration(s) & References \\
\hline Costunolide & $\begin{array}{l}\text { Inhibits production of TNF, IL-1 } \beta \text { and IL-6 by LPS-stimulated } \\
\text { macrophages }(0.1,0.5 \& 1 \mu \mathrm{M}) .\end{array}$ & {$[111,112]$} \\
\hline Helenalin & Inhibits TNF and IL-6 secretion by ASMCs $(1 \mu \mathrm{M})$. & {$[113]$} \\
\hline & EPA and DHA Lower BALF concentration of pro-inflammatory & Ref? \\
n-3 PUFA & Cytokines IL-1 a, IL-2, IL-5, IL-9, IL-13, G-CSF and RANTES. & \\
\hline
\end{tabular}

Table 5. Phytochemical inhibitors of proinflammatory cytokines

\subsubsection{Chemokines and chemokine receptors blockers}

Chemokines (CC) and their receptors (CCR) play a crucial role in the recruitment of inflammatory cells into the airways and development of asthma. CC-chemokine receptor 3 CCR3, CCR4, and CRTH2 antagonists are being targets currently being evaluated for the treatment of asthma. A study found that treatment of asthmatic mice with an anti-CCR3 monoclonal antibody inhibits allergen-induced eosinophilia and CD34 $4^{+}$progenitor cell infiltration into the lung, which is accompanied by reduced AHR [114, 115]. RS-1748, a CCR4 antagonist, inhibits OVA-induced airway inflammation in guinea pigs [116]. The number of CCR4-expressing Th2 cells is increased in the airways of asthmatic patients which can be blocked by a selective CCR4 antagonist [117], and therefore could be an effective therapy for asthma. Ramatroban and closely related TM30089 are antagonists for CRTH2, a chemokine receptor expressed on Th2 cells. They have been shown to attenuate allergen-induced EAR and LAR in animal models of asthma $[118,119]$. Some of the phytochemicals indicated against chemokines function are listed in Table 6.

\begin{tabular}{|c|c|c|}
\hline $\begin{array}{l}\text { Phytochemicals } \\
\text { Flavonoids }\end{array}$ & Target/Function and Effective Concentration(s) & References \\
\hline Apigenin & $\begin{array}{l}\text { Suppresses the production of MDC and IP-10 in THP-1 cells }\left(10^{-6}\right. \\
\left.\text { and } 10^{-5} \mathrm{M}\right) \text {. Inhibits release of LPS-induced MCP- } 1 \text { in } \mathrm{J} 774.2 \\
\text { macrophages }(10 \& 30 \mu \mathrm{M}) \text {. Inhibits production of IL- } 8 \text { in HMC-1 } \\
\text { cells. }\end{array}$ & {$[58,120,121]$} \\
\hline Baicalein & $\begin{array}{l}\text { Inhibits IL-8 and MCP-1 release in activated human mast cells. } \\
\text { Inhibits eotaxin production in human dermal fibroblasts }(10 \mathrm{\mu g} / \\
\mathrm{mL}) \text {. }\end{array}$ & {$[59,122]$} \\
\hline Baicalin & $\begin{array}{l}\text { Reduces IL-8 levels in plasma and BALF in cigarette smoke-induced } \\
\text { COPD rat model. Inhibits eotaxin production in human dermal } \\
\text { fibroblasts ( } 10 \mu \mathrm{g} / \mathrm{mL}) \text {. }\end{array}$ & {$[60,122]$} \\
\hline
\end{tabular}




\section{Phytochemicals}

Flavonoids

\begin{tabular}{|c|c|c|}
\hline Chrysin & $\begin{array}{l}\text { Inhibits TNF-induced IL-8 expression in HEK } 293 \text { cells }(20,40 \text { \& } 80 \\
\mu M) \text {. }\end{array}$ & [123] \\
\hline Chrysol & Inhibits MCP-1 production in antigen-stimulated RBL-2H3. & {$[62]$} \\
\hline Fisetin & $\begin{array}{l}\text { Inhibits TNF-induced IL-8 expression in HEK } 293(20,40 \& 80 \mu \mathrm{M}) \text {. } \\
\text { Inhibits IL-8 production in HMC-1 cells. }\end{array}$ & {$[65,123]$} \\
\hline Genistein & $\begin{array}{l}\text { Blocks HDM-induced IL-8 release in human lung epithelial cells (50 } \\
\mu \mathrm{M}) \text {. Inhibits IL-8 release in TNF-stimulated human keratinocytes } \\
(60 \mu \mathrm{M}) \text {. Inhibits chemokine-stimulated eosinophil adherence }\left(10^{-7} \text {, }\right. \\
\left.10^{-6} \text { and } 10^{-5} \mathrm{M}\right) \text {. }\end{array}$ & [124-126] \\
\hline Isoliquiritigenin & $\begin{array}{l}\text { Inhibits eotaxin-1 secretion in human fetal lung fibroblasts }\left({ } C_{50}\right. \\
0.92 \pm 0.05 \mu \mathrm{g} / \mathrm{mL}) \text {. }\end{array}$ & [127] \\
\hline Kaempferol & $\begin{array}{l}\text { Suppresses LPS-induced production of MDC, IP-10 and IL- } 8 \text { in } \\
\text { THP-1. Inhibits MCP-1 production in antigen-stimulated RBL-2H3 } \\
\text { and J774.2 macrophages ( } 10 \& 30 \mu \mathrm{M}) \text {. Inhibits TNF-induced IL-8 } \\
\text { expression in HEK } 293(20,40 \& 80 \mu \mathrm{M}) \text {. }\end{array}$ & {$[62,123,128,129]$} \\
\hline Kuraridin & $\begin{array}{l}\text { Suppresses expression of MCP-1 in LPS-stimulated macrophages ( } 40 \\
\mu \mathrm{M} \text { ). }\end{array}$ & [66] \\
\hline Kurarinone & $\begin{array}{l}\text { Inhibits MCP-1-induced chemotaxis of THP-1 cells }\left(\mathrm{IC}_{50} 19.2 \mathrm{\mu g} / \mathrm{mL}\right) \text {. } \\
\text { Suppresses expression of MCP-1 in LPS-stimulated macrophages ( } 40 \\
\mu \mathrm{M}) \text {. }\end{array}$ & {$[130]$} \\
\hline Luteolin & $\begin{array}{l}\text { Inhibits TNF-induced expression of MCP-1 }(10,20 \& 30 \mu \mathrm{M}) \text { and } \\
\text { CXCL-1 ( } 20 \& 30 \mu \mathrm{M}) \text { expression in keratinocytes. Inhibits induction } \\
\text { of IL-8 in activated HMC-1 cells }(50 \mu \mathrm{M}) \text { and hCBMCs. }\end{array}$ & {$[70,131,132]$} \\
\hline Morin & Inhibits IL-8 production in antigen-stimulated hCBMCs (100 $\mu \mathrm{M})$. & {$[75]$} \\
\hline Myricetin & Inhibits IL-8 production in antigen-stimulated hCBMCs $(100 \mu \mathrm{M})$. & [75] \\
\hline
\end{tabular}

Decreases secretion of PMA-induced IL-8 in HL-60 cells (20 $\mu \mathrm{M})$.

Suppresses LPS-induced IL-8 production by macrophages and

Naringenin human whole-blood samples ( $25 \& 50 \mu \mathrm{g} / \mathrm{mL}$ ). Inhibits expression of RANTES and eotaxin-1 in BALF and lungs in asthmatic mouse model (50 \& $100 \mathrm{mg} / \mathrm{kg}$ body $\mathrm{wt}$.).

Decreases production of IL-8 (3 \& $30 \mu \mathrm{M})$ and MCP-1 $\left(10^{-4}, 10^{-5}\right.$ and

Quercetin $\left.10^{-6} \mathrm{M}\right)$ in activated HMC-1 and IL-8 in human bronchial epithelial cells $(0.1,10 \& 25 \mu \mathrm{M})$.

Decreases production of MIP-1a in lung tissue of mice with LPS-

Resveratrol induced acute lung injury (10 mg/kg body wt.). Reduces TNFinduced IL-8 release in HASMCs in COPD. Inhibits IFNY-induced production of IP-10 and MIG in macrophages and HMC-1 cells.

\section{References}




\section{Phytochemicals} Flavonoids

\begin{tabular}{|c|c|c|}
\hline & Inhibits IL-8 production in THP-1 cells $(0.1,1,10 \& 100 \mu \mathrm{g} / \mathrm{mL})$ & \\
\hline & $\begin{array}{l}\text { Attenuates C } 5 \text { a-induced MIP-1a production in mouse model (1 } \\
\mathrm{mg} / \mathrm{kg} \text { body wt.). }\end{array}$ & \\
\hline Tectorigenin & Inhibits MCP-1 expression in endothelial cells. & {$[138]$} \\
\hline Wogonin & $\begin{array}{l}\text { Suppresses mite antigen-induced TARC expression in human } \\
\text { keratinocytes ( } 250 \mathrm{ng} / \mathrm{mL} \text { ). }\end{array}$ & [139] \\
\hline Polyphenols & & \\
\hline Caffeic acid & $\begin{array}{l}\text { Decreases IL-8 release in chitinase-activated human airway } \\
\text { epithelial cells }(1 \mu \mathrm{M}) \text {. Inhibits production of eotaxin in human lung } \\
\text { fibroblast cells }(1,10 \& 100 \mu \mathrm{M}) \text {. Inhibits IP-10 expression in allergic } \\
\text { patients' DCs (10 } \mu \mathrm{M}) \text {. Decreases expression of CXCR4 receptor on } \\
\text { CD4 T cells }(20 \mu \mathrm{g} / \mathrm{mL}) \text {. Suppresses IL-8 levels in asthmatic patients } \\
\text { (13\% soln.). }\end{array}$ & {$[89,90,140-143]$} \\
\hline Curcumin & Inhibits tryptase-induced IL-8 release in eosinophils $(25 \mu \mathrm{M})$. & \\
\hline EGCG & $\begin{array}{l}\text { Inhibits IL-8 release in TNF-stimulated human keratinocytes }(0.5,1 \text {, } \\
5 \text { \& } 10 \mu \mathrm{M} \text { ). Reduces airway inflammation in asthmatic mouse } \\
\text { model by binding to chemokines CXCL9, CXCL10 and CXCL11 ( } 10 \text { \& } \\
100 \mu \mathrm{M}) \text {. Decreases MCP-1 and CCR2 expression on THP-1 cells ( } 100 \\
\mu \mathrm{M}) \text {. Attenuates production of MIP-2 in lungs of mice with LPS- } \\
\text { induced acute lung injury. Reduces expression of MCP-1 and IL-8 in } \\
\text { HMC-1 cells ( } 100 \mu \mathrm{M}) \text {. Inhibits neutrophil migration by suppression } \\
\text { of CINC-1 production ( } 15,50 \& 150 \mu \mathrm{g} / \mathrm{mL} \text { ). Downregulates } \\
\text { cigarette smoke-induced IL-8 release from bronchial epithelial cells. }\end{array}$ & $\begin{array}{c}{[97,99,125,} \\
144-147]\end{array}$ \\
\hline Gallic acid & $\begin{array}{l}\text { Inhibits production of IL- } 8 \text { and TARC }(5 \& 10 \mu \mathrm{g} / \mathrm{mL}) \text { in neutrophils } \\
\text { and keratinocytes respectively. Inhibits eotaxin and RANTES in } \\
\text { pleural lavage fluid of allergen-challenged mouse model (100 } \\
\mathrm{mg} / \mathrm{kg} \text { body wt.). Inhibits IL- } 8 \text { release in HMC-1 cells }(10 \mu \mathrm{M}) \text {. }\end{array}$ & {$[148-150]$} \\
\hline Rosmarinic acid & $\begin{array}{l}\text { Inhibits LPS-induced production of MCP-1 and MIP-1a in bone- } \\
\text { marrow derived DCs ( } 100 \mu \mathrm{M}) \text {. Reduces diesel exhaust particles- } \\
\text { induced MIP-1a, MCP-1 and KC expression in mice lung ( } 4.6 \mu \mathrm{g} / \mathrm{kg} \\
\text { body wt.). Inhibits expression of eotaxin in lungs of mite antigen- } \\
\text { sensitized mice ( } 1.5 \mathrm{mg} / \mathrm{kg} \text { body wt. PO). Inhibits expression of } \\
\text { CCL11 and CCR3 genes induced by TNF in human dermal fibroblast } \\
\text { cells. }\end{array}$ & {$[102,107,110,151]$} \\
\hline Helenalin & Inhibits eotaxin and RANTES secretion in ASMCs ( $1 \mu \mathrm{M})$. & {$[113]$} \\
\hline
\end{tabular}

Table 6. Phytochemical inhibitors of chemokines 


\subsubsection{Miscellaneous: IgE, histamine, enzymes}

The activation of mast cells involves the cross-linking of $\operatorname{IgE}$ bound to the $\mathrm{F}_{\mathrm{C}} \varepsilon \mathrm{RI}$ surface receptor. Activation is measured in the laboratory by the release of the Beta-hexosaminidase enzyme ( $\beta$-hex) from cytosolic granules into the interstitial fluid. The following compounds (Table 7) have been found to be inhibitors of $\beta$-Hex release in vitro and have to potential to be inhibitor of IgE-antigen activation.

\begin{tabular}{|c|c|c|}
\hline Phytochemicals & $\mathrm{IC}_{50}$ & References \\
\hline \multicolumn{3}{|l|}{ Anti-oxidants } \\
\hline Vitamin A/carotenoid & $?$ & [152] \\
\hline \multicolumn{3}{|l|}{ Flavonoids } \\
\hline Apigenin & $4.5 \mu \mathrm{M}$ & [153] \\
\hline Baicalein & $17 \mu \mathrm{M}$ & [153] \\
\hline Chrysin & $?$ & {$[62]$} \\
\hline Daidzein & $?$ & [83] \\
\hline Fisetin & $3 \mu \mathrm{M}$ & [73] \\
\hline Genistein & $28.5 \mu \mathrm{g} / \mathrm{mL}$ & [83] \\
\hline Ginkgetin & $6.52 \mu \mathrm{M}$ & [154] \\
\hline Glycitein & $28.5 \mu \mathrm{g} / \mathrm{ml}$ & [83] \\
\hline Isoliquiritigenin & $24 \mu \mathrm{M}$ & [155] \\
\hline Kaempferol & $7.5 \mu \mathrm{M}$ & {$[62]$} \\
\hline Luteolin & $3 \mu \mathrm{M}$ & [73] \\
\hline Morin & $51 \mu \mathrm{M}$ & [153] \\
\hline Myricetin & $6.7 \mu \mathrm{M}$ & [153] \\
\hline Naringenin & $29 \mu \mathrm{M}$ & [156] \\
\hline Quercetin & $3 \mu \mathrm{M}$ & [73] \\
\hline Resveratrol & $14 \mu \mathrm{M}$ & [157] \\
\hline Sophoflavanone G & $20 \mu \mathrm{M}$ & [158] \\
\hline Tectorigenin & $0.193 \mathrm{mM}$ & [159] \\
\hline \multicolumn{3}{|l|}{ Polyphenols } \\
\hline Caffeic acid & $?$ & [160] \\
\hline Curcumin & $5.3 \mu \mathrm{M}$ & [161] \\
\hline EGCG & $?$ & [162] \\
\hline Ginkgetin & $?$ & \\
\hline
\end{tabular}




\begin{tabular}{cccc}
\hline Phytochemicals & IC $_{50}$ & References \\
\hline Medicarpin & $>100 \mu \mathrm{M}$ & {$[155]$} \\
\hline Resmarinic acid & $?$ & {$[160]$} \\
\hline & & & \\
\hline & Celastrol & $?$ & {$[163]$} \\
\hline
\end{tabular}

Table 7. Phytochemical inhibitors of beta-hexosaminidase enzyme

\subsection{Inhibitors of intracellular signaling pathways}

The previous section focused on compounds that affected the function of extracellular, cell surface/receptor and cell to cell interactions. The following group of compounds affect the intercellular functions of the cells particular the components of cell signalling pathways.

\subsubsection{Protein kinase inhibitor}

Protein kinases have a key role in the expression and activation of inflammatory mediators implicated in airway inflammation. Enhanced activation of p38 mitogen-activated protein kinase (MAPK), c-Jun N-terminal kinase (JNK), spleen tyrosine kinase (Syk), and phosphoinositol 3-kinase (PI3K) signaling pathways have all been proposed to have a role in the pathogenesis of asthma.

p38 MAPK is involved in the airway inflammation and remodeling. A selective synthetic p38 MAPK inhibitor SB2439063 reduces synthesis of Th2 cytokines [54] and thus has a potential application in asthma treatment. Inhaled p38 MAPK antisense oligonucleotide attenuates asthma in OVA-sensitized and -challenged mice [165]. The natural product limonene inhibits eosinophil migration in p38 MAPK dependent manner and was investigation in an in vitro bronchial asthma model [166].

JNK activity is increased in corticosteroid-resistant asthma and SP600125, a JNK inhibitor, reduces cytokines expression and inflammatory cells accumulation in BALF of asthmatic animal models. Celastrol, a natural compound, modulates the expression of JNK in asthma [167]. It supresses allergen-induced mouse asthma by decreasing expression of MAP kinases, ERK and JNK [168].

Syk is a protein kinase involved in signal transduction in many inflammatory cells, and its aberrant regulation is associated with asthma, thus is considered an interesting target for asthma therapies. BAY 61-3606, a synthetic Syk inhibitor, inhibits inflammatory mediator release from mast cells, basophils, eosinophils, and monocytes, and reduces allergic asthma in rats [169]. Eupatilin, a biological extract, inhibits Syk and blocks downstream signaling pathways in mast cell from guinea pig lung tissues, leading to inhibition of mediator release [170]. Thus, Syk inhibitors may have use clinically as a treatment for asthma. 
The PI3K pathway plays a major role in the pathogenesis of asthma by promoting eosinophil and neutrophil recruitment and degranulation [171]. Sorbus commixta water extract, an antiinflammatory medicinal plant, remarkably blocks PI3K activity in antigen-activated macrophages, suggesting the usefulness of PI3K inhibitors in asthma [172].

\subsubsection{Transcription factor inhibitors}

The increased expression of various inflammatory proteins seen in asthma is the result of enhanced gene transcription, since many of the genes are not expressed in normal cells but are selectively induced during inflammation. Changes in gene transcription are under the control of transcription factors which therefore play a key role in the pathogenesis of asthma.

Transcription factors such as nuclear factor- $\kappa \mathrm{B}(\mathrm{NF}-\kappa \mathrm{B})$, GATA-3, signal transducers and activators of transcription protein (STAT)s, nuclear factor of activated T cells (NFAT), and peroxisome proliferator-activated receptors (PPAR) have been implicated in asthma and therefore represent therapeutic targets.

$\mathrm{NF}-\kappa \mathrm{B}$ is induced by many factors involved in asthmatic inflammation and is implicated in glucocorticoid-resistant asthma. Inhibition of I $\kappa$ B (inhibitor of NF- $\kappa B$ ) by small molecule inhibitors suppresses inflammatory responses in mast cell [173], OVA-induced rat model of airway inflammation [174], and macrophages from BALF of asthmatic patients. A number of herbal preparations (i.e. andrographolide and narigenin) have been demonstrated to inhibit airway inflammation and AHR by inhibiting NF- $\kappa$ B activity in OVA-induced murine asthma $[78,175]$. Many inhibitors of NF- $\kappa B$ have been identified belonging to the Flavonoids, Polyphenols and Terpenoids classes of compounds as well as n-3 PUFA (see Table 8).

\begin{tabular}{llll}
\hline Flavonoid & Polyphenols & Terpenoids & PUFA \\
\hline Apigenin & CAPE & Parthenolide & n-3 PUFA \\
Capsaicin & Curcumin & Costunolide & \\
Fisetin & Epigallocatechin-3-gallate & Helenalin & \\
Kuraridin & Gallic acid & Celastrol & \\
Kurarinone & Gingerol & Celaphanol A & \\
Luteolin & Rosmarinic acid & Kamebanin & \\
Myrecitin & & Kamebacetal A & \\
Naringenin & & Excisanin A & \\
Quercetin & & Orbiculin & \\
Resveratrol & & \\
\hline
\end{tabular}

Table 8. Naturally occurring NF-kB inhibitors

GATA-3 is a critical transcription factor that is specifically expressed by Th2 cells and is involved in their differentiation [176]. GATA-3 has been indicated in the development of airway eosinophilia and expression is increased in atopic asthma [177] and therefore is an obvious target for inhibition. Direct inhibition by using a specific antisense oligonucleotide or 
interference RNA promises a novel approach for asthma treatment [178]. Polyphenols, such as apigenin and quercetin, ameliorate asthma symptoms, and suppress the translocation of GATA-3 in the cytosol of lung tissue of OVA-sensitized and -challenged mice [179].

NFAT transcription factor is mostly involved in the production of Th2 cytokines through its interaction with GATA-3 and activator protein-1 (AP-1) [180]. Immunosupressive drugs cyclosporin A and FK506 block NFAT activation [181]. The use of peptides known as inhibitors of NFAT-calcineurin association (INCA) represents an alternative asthma treatment strategy [182].

PPARs are transcription factors belonging to the nuclear receptor superfamily activated by PUFA derivatives, oxidized fatty acids and phospholipids. PPAR $\gamma$ activation might exhibit anti-inflammatory properties in different inflammatory processes. In a murine model of asthma, treatment with PPAR $\gamma$ ligand ciglitazone significantly reduces AHR and lung inflammation [183]. PPAR $\alpha$ and PPAR $\gamma$ ligands also decreases allergen-induced AHR, lung inflammation as well as serum IgE levels in different asthma models [184]. Popular antiasthmatic Traditional Chinese Medicine San-ao Decoction (SAD), comprising Herba Ephedrae, Radix et Rhizoma Glycyrrhizae and Seneb Armeniacae Amarum, has a significant effect on PPAR $\gamma$ activation [185].

\subsection{Inhibitors of oxidative stress}

Oxidative stress plays a critical role in the development of asthmatic conditions. Oxidative stress and its by-products drive a Th2-dependent immune response. A number of antioxidants have been explored for their anti-inflammatory and anti-asthmatic properties, and a number of natural products have emerged as promising candidates. Resveratrol, a component of red wine, possesses anti-inflammatory and antioxidant properties. It inhibits inflammatory cytokines release in patients with chronic obstructive pulmonary diseases (COPD) [186] and may be beneficial in asthma. Several other biological compounds such as Sanguisorba offcinalis [187], aqueous extract from the root of Platycodi Radix [188], stem and bark of Ulmus davidiana [189], and Alpinia katsumadai seed extracts [190] attenuate oxidative stress and asthmatic activity in OVA-induced murine asthma. The flavonoids and polyphenols are the main groups of compounds that display anti-oxidative properties as listed in table 9.

\begin{tabular}{|c|c|c|}
\hline Phytochemicals & Function and effective concentration(s) & References \\
\hline \multicolumn{3}{|l|}{ Flavonoids } \\
\hline Apigenin & Suppresses LPS-induced NO production in RAW264.7 macrophages & [191] \\
\hline Baicalein & $\begin{array}{l}\text { Inhibits LPS-induced NO production and iNOS expression in } \\
\text { RAW264.7 macrophages }\end{array}$ & [192] \\
\hline Chrysin & $\begin{array}{l}\text { Inhibits NO production }\left(\mathrm{IC}_{50} 7.50 \pm 1.84 \mu \mathrm{M}\right) \text { in LPS-activated } \\
\text { RAW264.7 macrophages }\end{array}$ & [74] \\
\hline Fisetin & Inhibits TNF-induced ROS production in HEK cells & [123] \\
\hline
\end{tabular}




\begin{tabular}{|c|c|c|}
\hline Phytochemicals & Function and effective concentration(s) & References \\
\hline Kaempferol & $\begin{array}{l}\text { Inhibits NO production }\left(\mathrm{IC}_{50} 9.83 \pm 1.55 \mu \mathrm{M}\right) \text { in LPS-activated } \\
\text { RAW264.7 macrophages }\end{array}$ & [74] \\
\hline Kuraridin & $\begin{array}{l}\text { Inhibits ROS, NO production ( } 20 \& 40 \mu \mathrm{M} \text { ) and iNOS gene } \\
\text { expression }(40 \mu \mathrm{M}) \text { in LPS-activated RAW264.7 macrophages. }\end{array}$ & {$[66]$} \\
\hline Kurarinone & $\begin{array}{l}\text { Inhibits ROS, NO production ( } 40 \mu \mathrm{M} \text { ) and iNOS gene expression (40 } \\
\mu \mathrm{M} \text { ) in LPS-activated RAW264.7 macrophages. }\end{array}$ & {$[66]$} \\
\hline Luteolin & $\begin{array}{l}\text { Inhibits NO production }(4,8 \& 16 \mu \mathrm{M}) \text { in LPS-activated RAW264.7 } \\
\text { macrophages. }\end{array}$ & {$[67]$} \\
\hline Morin & $\begin{array}{l}\text { Inhibits NO production }\left(\mathrm{IC}_{50} 44.86 \pm 1.05 \mu \mathrm{M}\right) \text { in LPS-activated } \\
\text { RAW264.7 macrophages }\end{array}$ & [74] \\
\hline Naringenin & $\begin{array}{l}\text { Inhibits lung iNOS expression in allergen-induced mouse asthma } \\
\text { model }\end{array}$ & [78] \\
\hline Quercetin & $\begin{array}{l}\text { Inhibits NO production }\left(\mathrm{IC}_{50} 36.9 \pm 1.24 \mu \mathrm{M}\right) \text { in LPS-activated } \\
\text { RAW264.7 macrophages }\end{array}$ & {$[74]$} \\
\hline Resveratrol & $\begin{array}{l}\text { Inhibits NO production in mice with acute lung injury }(1 \mathrm{mg} / \mathrm{kg} \\
\text { body wt.). }\end{array}$ & [85] \\
\hline \multicolumn{3}{|l|}{ Polyphenols } \\
\hline Caffeic acid & $\begin{array}{l}\text { Reduces ROS levels in BALF of OVA-sensitized and -challenged mice } \\
(10 \mathrm{mg} / \mathrm{kg} \text { body wt. IP). }\end{array}$ & [88] \\
\hline Curcumin & $\begin{array}{l}\text { Reduces iNOS expression in lung tissue of OVA-sensitized asthmatic } \\
\text { mice. }\end{array}$ & [91] \\
\hline EGCG & $\begin{array}{l}\text { Reduces NOS activity in lungs of OVA-sensitized asthmatic guinea } \\
\text { pigs. }\end{array}$ & {$[96]$} \\
\hline Hydroxytyrosol & $\begin{array}{l}\text { Inhibits } \mathrm{NO}_{2} \text { production as well as iNOS expression in THP-1 cells ( } 50 \\
\& 100 \mu \mathrm{M})\end{array}$ & [104] \\
\hline Rosmarinic acid & Inhibits formation of ROS and RNS in activates macrophages & [193] \\
\hline Helenalin & Inhibits iNOS expression in LPS-stimulated macrophages (10 $\mu \mathrm{M})$ & [137] \\
\hline n-3 PUFA & $\begin{array}{l}\text { Decreases exhaled NO from asthma patients challenged with mite } \\
\text { allergen }\end{array}$ & [194] \\
\hline
\end{tabular}

Table 9. Phytochemical inhibitors of oxidative stress

\section{Experimental models of asthma}

Understanding respiratory sensitization mechanisms is the first step to designing therapeutic agents that may relieve patients of their asthma symptoms. A number of in vitro and in vivo experimental models are able to reproduce one or more features of allergic response and have 
been studied for a few decades. Animal models of asthma are the best characterized in terms of the inflammatory and remodeling processes. The use of gene knockout and transgenic animals and the therapeutic administration of antibodies or pharmacological antagonists/ inhibitors have helped to identify a range of pre-clinical targets for subsequent evaluation in humans. Small animal models of asthma, using mice, rats and guinea pigs, are most commonly used. Most of these models are based on active sensitization to an allergen such as OVA via the airways. In vitro model systems using inflammatory cells and airway-related cell types are widely used in studies on immuno-biological mechanisms of asthma. A more detailed description of the most commonly used models of asthma can be found in Table 10.

\begin{tabular}{|c|c|c|}
\hline In Vivo Model & $\begin{array}{l}\text { Route(s) of } \\
\text { Administration }\end{array}$ & Primary Effects \\
\hline $\begin{array}{l}\text { OVA-induced allergic } \\
\text { asthma }\end{array}$ & $\begin{array}{l}\text { Intranasal or aerosol } \\
\text { challenge, intrathoracic } \\
\text { inoculation, intradermal } \\
\text { challenge }\end{array}$ & $\begin{array}{l}\text { Increased serum IgE levels, histological changes in airways } \\
\text { including cellular infiltration, mediator release, AHR, and } \\
\text { remodeling. }\end{array}$ \\
\hline $\begin{array}{l}\text { LPS lung inflammation } \\
\text { model }\end{array}$ & Intranasal & $\begin{array}{l}\text { Leukocytes (mainly neutrophils) recruitment to lung within } 4 \mathrm{hr} \\
\text { of LPS treatment. }\end{array}$ \\
\hline House dust mite exposure & $\begin{array}{l}\text { Intraperitoneal } \\
\text { sensitization followed by } \\
\text { inhalational challenge }\end{array}$ & $\begin{array}{l}\text { Increased serum IgE levels, histological changes in airways } \\
\text { including cellular infiltration, mediator release, AHR, and } \\
\text { remodeling. }\end{array}$ \\
\hline $\begin{array}{l}\text { Infection by Aspergillus } \\
\text { fumigatus }\end{array}$ & $\begin{array}{l}\text { Intraperitoneal } \\
\text { sensitization followed by } \\
\text { inhalational challenge }\end{array}$ & $\begin{array}{l}\text { Increased serum IgE levels, histological changes in airways } \\
\text { including cellular infiltration, mediator release, AHR, and } \\
\text { remodeling. }\end{array}$ \\
\hline $\begin{array}{l}\text { Ragweed allergen } \\
\text { exposure }\end{array}$ & $\begin{array}{l}\text { Intraperitoneal } \\
\text { sensitization followed by } \\
\text { inhalational challenge }\end{array}$ & Airway inflammation and AHR. \\
\hline $\begin{array}{l}\text { Infection with Ascaris } \\
\text { suum }\end{array}$ & $\begin{array}{l}\text { Subcutaneous and } \\
\text { intratracheal sensitization, } \\
\text { aerosol challenge }\end{array}$ & , Bronchoconstriction, AHR and cellular infiltration. \\
\hline In Vitro Cell Model & Cell Type & Primary Response(s) \\
\hline \multicolumn{3}{|l|}{ Mast cells: } \\
\hline Human mast cells & $\begin{array}{l}\text { CD34+-derived primary } \\
\text { mast cells, cord blood } \\
\text { mast cells, skin mast cells, } \\
\text { lung mast cells, LAD2, } \\
\text { LUVA, HMC-1, RBL-2H3 }\end{array}$ & $\begin{array}{l}\text { Release of proinflammatory mediators such as histamine, } \\
\text { tryptase, chymase, cytokines, chemokines, leukotrienes, and } \\
\text { prostaglandins. }\end{array}$ \\
\hline Rodent mast cells & $\begin{array}{l}\text { Bone marrow-derived } \\
\text { mast cells, peritoneal mast } \\
\text { cells }\end{array}$ & $\begin{array}{l}\text { Release of proinflammatory mediators such as histamine, } \\
\text { ittryptase, chymase, cytokines, chemokines, leukotrienes, and } \\
\text { prostaglandins. }\end{array}$ \\
\hline Eosinophils & $\begin{array}{l}\text { Primary cells, EoL-1, } \\
\text { AML14.3D10 }\end{array}$ & $\begin{array}{l}\text { Release of proinflammatory mediators such as ECP, EPO, EDN, } \\
\text { MBP, cytokines, and chemokines. }\end{array}$ \\
\hline
\end{tabular}




\begin{tabular}{lll}
\hline In Vivo Model & $\begin{array}{l}\text { Route(s) of } \\
\text { Administration }\end{array}$ & Primary Effects \\
\hline Bronchial epithelial cells & $\begin{array}{l}\text { Primary cells, NHBE, } \\
\text { BEAS-2B }\end{array}$ & $\begin{array}{l}\text { Release of proinflammatory mediators such as cytokines and } \\
\text { chemokines. Morphological changes. }\end{array}$ \\
\hline Alveolar epithelial cells & Primary cells, A549 & $\begin{array}{l}\text { Release of proinflammatory mediators such as cytokines and } \\
\text { chemokines. Morphological changes. }\end{array}$ \\
\hline Monocytes/ & Primary cells, Mono- & $\begin{array}{l}\text { Release of proinflammatory mediators such as cytokines, } \\
\text { Macrophages }\end{array}$ \\
\hline & Mac-6, THP-1, RAW 264.7 & chemokines, leukotrienes, prostaglandins, ROS, and RNS. \\
Dendritic cells & CD34-DC, Mo-DC, KG-1, & $\begin{array}{l}\text { Release of proinflammatory mediators such as cytokines and } \\
\text { chemokines. }\end{array}$ \\
\hline
\end{tabular}

Table 10. In vivo and in vitro models for asthma studies

\section{Evidence for the association between diet and asthma}

\subsection{Antioxidants}

The airways are continuously exposed to oxidants, either generated endogenously by various metabolic reactions (e.g. from mitochondrial respiration or released from phagocytes) or derived from exogenous sources (e.g. air pollutants and cigarette smoke). Allergen-activated inflammatory cells from asthmatic patients produce more ROS than from healthy individuals. In addition, several inflammatory mediators including histamine, lipid mediators, cytokines, chemokines, ECP, and EPO are potential stimuli for ROS production in the airways, leading to asthma exacerbation.

Deficiency of endogenous antioxidant defenses has been reported in asthma [195]. Since a diet rich in vitamin A or carotenoids, vitamin C vitamin E, and flavonoids, has been associated with a decreased prevalence of asthma, understanding the relationship between dietary antioxidants and asthma-associated inflammatory responses has been a recent focus.

\subsubsection{Vitamin A and carotenoids}

A systemic review and meta-analysis by Allen et al. has shown that dietary vitamin A intake is significantly lower in asthmatic patients than in healthy subjects [196]. Asthmatic children have a lower serum vitamin A concentration than healthy controls [197]. Supplementation of the diet with lycopene, a carotene found in tomatoes and carrots, has a protective effect against asthma development in a murine model [198].

All-trans retinoic acid (ARTA), a derivative of vitamin A, inhibits airway inflammation in asthmatic rats. ARTA inhibits total cell counts and the proportion of inflammatory cells in BALF, suppresses the expression of NF- $\kappa$ B and intercellular adhering molecule-1 (ICAM-1), and increases the expression of ikB [199]. Retinoid acid also downregulates the expression of Th1 and Th2 chemokines in monocytes, including macrophage-derived chemokine and IP-10, 
which are all important in the inflammatory process [200]. Airway smooth muscle cell migration, which contributes to the airway remodeling in chronic asthma is also inhibited by ARTA [201]. However, excessive intake of vitamin A exacerbates pulmonary hyperresponsiveness in murine asthma model, suggesting that excessive vitamin A may increase the risk and severity of asthma [202].

Mechanistically, vitamin A may regulate bronchial hyperreactivity by altering the function and abundance of the muscarinic $\mathrm{M}(2)$ receptors in bronchial tissue [203]. Moreover, carotenoids may regulate activation of a variety of transcription factors. Treatment of cells exposed to oxidative stress with $\beta$-carotene suppresses oxidative stress-induced activation of NF- $\kappa \mathrm{B}$ and production of IL-6, TNF, and inflammatory cytokines. Carotenoids may influence the process of apoptosis in healthy cells. While the pro-apoptotic protein Bax is downregulated after induction of external stimuli, $\beta$-carotene is able to increase expression of the antiapoptotic protein $\mathrm{Bcl}-2$ in normal cells. In addition, $\beta$-carotene exhibits a pro-apoptotic effect in colon and leukemic cancer cells, and this effect occurs by a redox-dependent mechanism linked with NF- $\kappa \mathrm{B}$ activity. These dual roles of vitamin A, including carotenoids, on apoptosis provide the capability of carotenoids as an effective anti-inflammatory agent in various diseases.

\subsubsection{Vitamin C}

Many observational studies have reported associations between reduced dietary/blood vitamin $\mathrm{C}$ levels and reduced lung functions. Asthmatic children undergoing an exacerbation have significant lower serum levels of vitamin C [204]. There is a positive correlation between serum vitamin C levels and asthma development in children (OR=0.72 per $\mathrm{mg} / \mathrm{dl}, 95 \% \mathrm{CI}=0.55$, 0.95) [10]. Furthermore, asthma patients have significantly lower vitamin $C$ level in both the cellular and fluid-phase fraction in induced sputum [205]. Higher maternal intake of citrus fruits rich in vitamin $C$ during pregnancy is significantly associated with a reduced risk of allergic inflammation in the offspring [206]. Administration of vitamin C in OVA-challenged mice decreases AHR, influx of inflammatory cells in BALF and attenuates lung inflammation [207]. Similarly, high dose vitamin C supplementation significantly reduces eosinophilic infiltration in BALF and increases the Th1/Th2 cytokine secretion ratio; thus, skewing the Th1/ Th2 balance toward non-allergic Th1 immune response in asthmatic mice [208].

A randomized, placebo controlled, double-blinded crossover trial has shown that vitamin C supplementation ( $1500 \mathrm{mg} /$ day) attenuates asthma symptoms. Moreover, exhaled nitric oxide, urinary leukotriene $\mathrm{C}_{4}, \mathrm{D}_{4}, \mathrm{E}_{4}$ and $9 \alpha, 1 \beta$-prostaglandin $\mathrm{F}_{2}$ after exercise are downregulated [209]. On the contrary, there are also studies showing no significant effect of vitamin $C$ supplementation on asthma symptoms. For example, in a randomized, placebo-controlled, double-blind parallel group trial three hundred asthma patients provided with $1 \mathrm{~g} /$ day vitamin C or placebo for 6 weeks do not show any improvements of asthma symptoms [210], therefore, there is insufficient evidence from randomised-controlled trials to support the use of vitamin C for asthma treatment [211].

As its mechanism of action, vitamin C may regulate factors that can influence gene expression, apoptosis, and other cellular functions indicated in inflammation. In fact, vitamin C protects 
against cell death triggered by various stimuli, and major proportion of this protection is associated with its antioxidant ability [212]. Vitamin C inhibits the AP-1 activation by regulating MAPK-ERK pathway [213]. Treatment of cells exposed to UV-B irradiation with vitamin $C$ results in a $50 \%$ decrease in JNK phosphorylation, which activates AP-1, therewith inhibiting the JNK/AP-1 signaling pathways [214]. At present, however, evidence from randomized controlled trials is insufficient to recommend a specific role for vitamin $\mathrm{C}$ in the treatment of asthma due to variable study design and generally poor reporting system.

\subsubsection{Vitamin E}

The body of evidence from multiple studies suggests that a positive association between asthma outcomes and vitamin E intake or serum vitamin E levels. Asthmatic children have significantly lower serum levels of vitamin E than non-asthmatic children [204, 215]. A longitudinal birth cohort study has explored association between maternal plasma vitamin E, fetus and fetal lungs growth, and childhood asthma. The findings have shown that maternal vitamin E status has a positive effect on the growth of fetus and fetal lungs during early pregnancy and better asthma outcomes during childhood [216]. Moreover, high maternal vitamin $\mathrm{E}$ intake during pregnancy also reduces the risk of infantile wheeze [206]. Vitamin E intake is higher in control subjects than in asthma patients [217]. However there is no relationship found between serum vitamin E level and asthma [4, 218]. On the other hand, administration of vitamin $\mathrm{E}$ for 6 weeks does not have an effect on asthma features and serum immunoglobulin levels in adults [219].

Role of Vitamin E has been investigated in animal models of allergic asthma. Administration of Vitamin E to allergen-challenged mice reduces mitochondrial dysfunction, Th2 cytokines production, allergen-specific IgE, and expression of lipid mediators in lung leading to alleviation of asthmatic features [220]. Expression of IL-5 mRNA and protein in lung, and plasma IgE level are reduced after OVA sensitization and challenge compared to wild type mice in vitamin E transfer protein knockout mice [221]. Moreover, dietary supplementation with vitamin $\mathrm{E}$ affords variable degree of protection against ozone-induced enhanced airway response in allergen-sensitized guinea pigs [222]. However, oral $\alpha$-tocopherol has no protective effect on lung response in rat model of allergic asthma. There is no improvement in OVAinduced AHR, the inflammatory cell infiltrate and histological changes [223]. The observed opposite effects of vitamin E could be associated with the study design in an animal model of asthma. The effect of vitamin E deserves further evaluation.

Vitamin E may induce immunological effects via modulation of the functional activity of T cells and enhancing the phagocytic activity of peripheral granulocytes [224]. A derivative $\gamma$ tocopherol appears to be a more potent anti-inflammatory agent than $\alpha$-tocopherol. It decreases systemic oxidative stress, cytokine release from monocytes in asthmatic patients, and inhibits monocyte response to LPS and LPS-induced degradation of I $\kappa$ B and JNK activation [225]. There is a contradictory study demonstrating that $\gamma$-tocopherol elevates inflammation and ablates the anti-inflammatory benefit of the $\alpha$-tocopherol by regulation of endothelial cell signals during leukocyte recruitment in experimental asthma [226]. Dietary tocopherols are taken up from the intestine and transported via the lymph to the blood and then to the liver. 
In the liver, $\alpha$-tocopherol is transferred to plasma lipoproteins, resulting in retention of $\gamma$ tocopherol in tissues at $10 \%$ that of $\alpha$-tocopherol. On interpreting these two contradictory results, one should consider their serum levels with caution since low plasma level of $\gamma$ tocopherol $(1.2-7.0 \mu \mathrm{M})$ may act as prooxidant, while higher level of $\gamma$-tocopherol $(19.5 \mu \mathrm{M}$ at 8 days) exerts antioxidative and anti-inflammatory effects.

\subsubsection{Vitamin D}

Over the past several years, the role of vitamin D in immunomodulation has been studied and shown to have a significant impact on innate and adaptive immunity to infections, including the pathophysiology of allergic asthma. It has been proposed that the increase in allergy and asthma is a consequence of widespread vitamin D insufficiency which appears to be frequent in industrialized countries, reflecting the insufficient intake of diet-sourced vitamin D.

The serum vitamin D level is associated with asthma in children as well as adults. A randomized, placebo controlled clinical study with 1024 children suffering from mild-to-moderate persistent asthma has shown that Vitamin D deficiency ias associated with a higher rate of severe asthma [227]. There is a significant positive correlation between forced vital capacity percent predicted and serum vitamin D level children with asthma. Moreover, $91.6 \%$ of these asthmatic children are not sufficient in serum vitamin D level [228]. Low level of vitamin D in serum are also associated with increased hyperresponsiveness and reduced glucocorticoid response in adults with asthma [229]. These studies have indicated that the low serum vitamin $\mathrm{D}$ level is related to reduced lung function and higher risk of asthma. Reduced the risk of asthma exacerbation triggered by acute respiratory tract infection is observed in a vitamin $\mathrm{D}$ supplementation [230]. Higher consumption of vitamin D during pregnancy may reduce the risk of childhood wheeze and asthma.

One possible mechanism of vitamin D's protective effect against asthma can be that it inhibits the maturation process of dendritic cells by suppressing the expression of costimulatory molecules HLA-DR, CD86, CD80, the maturation marker CD83, and IL-12 which are important for the recruitment of Th1 cells [231]. Vitamin D also upregulates the expression of IL-10 receptor in dendritic cells, which is an anti-inflammatory cytokine. In addition, it can promote the production of FoxP3 positive and IL-10 positive regulatory T cells, and induce the release of IL-10, TGF- $\beta$ and CTLA-4 [232]. Furthermore, it may reverse steroid-resistance in asthmatic patients through induction of IL-10 secreting T-regulatory cells [233], and vitamin D has been shown to regulate expression of many genes in ASM cells, including genes previously implicated in asthma predisposition and pathogenesis [234].

\subsection{Flavonoids}

Flavonoids interfere with oxidation of lipids and other molecules and this strong antioxidative property makes them protective against airway diseases linked to oxidative stress. In fact, several epidemiologic studies suggest the beneficial effects of flavonoids on asthma. A population-based case-control study has shown that apple consumption and red wine intake are inversely associated with asthma prevalence or severity, perhaps due to a protective effect 
of flavonoids [18]. Moreover, a 30-year longitudinal epidemiological study has reported that the incidence of asthma is lower in populations with higher intake of flavonoids [235].

\begin{tabular}{|c|c|c|}
\hline Flavonoid Subclass & Dietary Flavonoids & Some Common Food Sources \\
\hline Anthocyanidins & $\begin{array}{l}\text { Cyanidin, Delphinidin, Malvidin, } \\
\text { Pelargonidin, Peonidin, Petunidin }\end{array}$ & $\begin{array}{l}\text { Red, blue, and purple berries; red and } \\
\text { purple grapes; red wine }\end{array}$ \\
\hline Flavanols & $\begin{array}{l}\text { Monomers (Catechins): } \\
\text { Catechin, Epicatechin, Epigallocatechin } \\
\text { Epicatechin gallate, Epigallocatechin } \\
\text { gallate } \\
\text { Dimers and Polymers: } \\
\text { Theaflavins, Thearubigins, } \\
\text { Proanthocyanidins }\end{array}$ & $\begin{array}{l}\text { Catechins: Teas (particularly green and } \\
\text { white), chocolate, grapes, berries, apples } \\
\text { Theaflavins, Thearubigins: Teas } \\
\text { (particularly black and oolong) } \\
\text { Proanthocyanidins: Chocolate, apples, } \\
\text { berries, red grapes, red wine }\end{array}$ \\
\hline Flavanones & Hesperetin, Naringenin, Eriodictyol & $\begin{array}{l}\text { Citrus fruits and juices, e.g., oranges, } \\
\text { grapefruits, lemons }\end{array}$ \\
\hline Flavonols & $\begin{array}{l}\text { Quercetin, Kaempferol, Myricetin, } \\
\text { Isorhamnetin }\end{array}$ & $\begin{array}{l}\text { Widely distributed: yellow onions, scallions, } \\
\text { kale, broccoli, apples, berries, teas }\end{array}$ \\
\hline Flavones & Apigenin, Luteolin & Parsley, thyme, celery, hot peppers \\
\hline Isoflavones & Daidzein, Genistein, Glycitein & Soybeans, soy foods, legumes \\
\hline
\end{tabular}

Table 11. Common dietary flavanoids.

Beyond antioxidative effects, flavonoids inhibit the release of histamine and other preformed granule associated mediators by inhibiting the activation of basophils and mast cells [66]. Flavonoids inhibit synthesis of IL-4, IL-13, and CD40 ligand but initiate generation of new phospholipid-derived mediators. One of the well-characterized flavonoids, quercetin, inhibits eosinophilic secretion of Charcot-Leyden crystal protein and ECP in a concentration-dependent manner. Very recently, Li et al. demonstrated that apigenin exhibits an anti-inflammatory activity in a murine asthma model and can switch the immune response to allergens toward the Th1 profile. These findings suggest that flavonoids are anti-allergenic and anti-inflammatory agents effective in treating/preventing asthma.

Vascular changes are one of the major components of asthmatic pathogenesis. These changes include an increase in vascular permeability, vascular dilation/engorgement, and vasculogenesis/angiogenesis. Flavonoids and their related compounds have been shown to modulate expression of HIF-1, VEGF, matrix metalloproteinases (MMPs), and epidermal growth factor receptor but also inhibit NF-kB, PI3K/Akt, and ERK1/2 signaling pathways [236]. These observations suggest that flavonoids as well as their related compounds inhibit certain steps of angiogenesis including cell migration, microcapillary tube formation, and MMP expression.

Many flavonoids have been tested for their anti-asthma effect. Quercetin decreases the eosinophil recruitment, reduces IL-5 and IL-4 levels, and inhibits NF- $\kappa$ B activation in BALF in OVA-induced mouse model [237]. It also regulates Th1/Th2 balance by enhancing IFN- $\gamma$ and decreasing IL-4 levels in mouse asthma model [179]. Naringenin alleviates airway inflamma- 
tion and reactivity by decreasing serum total IgE level and IL-4, IL-13 level in BALF and inhibiting NF- $\kappa B$ activity [78]. Licorice is a Traditional Chinese Medicine, which contain many flavonoids. Flavonoids extracted from licorice attenuates LPS-induced acute pulmonary inflammation by inhibiting inflammatory cells infiltration and inflammatory mediator release [238]. Neutrophils, macrophages and lymphocytes accumulation in BALF, lung TNF and IL-1 $\beta$ mRNA expression and lung myeloperoxidase activity are reduced; whereas BALF superoxide dismutase activity is increased [238]. Flavonoids from red algae decrease eosinophil infiltration, levels of TNF, IL-4 and IL-5 in BALF, airway luminal narrowing, AHR and level of allergen-specific IgE in the serum [239]. A complex mixture of bioflavonoids derived from purple passion fruit peel extract supplemented to asthma patients in a randomized, placebo-controlled, double-blinded trial alleviates asthma clinical symptoms, including FVC and FEV1 [240].

\subsection{Resveratrol}

Resveratrol scavenges intracellular ROS by inducing and stabilizing antioxidant enzymes such as catalase, SOD, and glutathione peroxidase hemoxygenase. In addition to its reducing properties, resveratrol has been shown to attenuate inflammation via inhibition of prostaglandin production [241] and to decrease the phosphorylation of ERK1/2, COX-2 activity, and activity of various transcription factors including NF- $\kappa$ B, STAT3, HIF- $1 \alpha$, and $\beta$-catenin [236]. Resveratrol also inhibits protein kinases (e.g. src, PI3K, JNK, and Akt) and the production of inflammatory mediators (e.g. IFN- $\gamma$, TNF, COX-2, iNOS, CRP and various interleukins). Recent studies have reported that resveratrol activates sirtuin1 (SIRT1) which is modulates apoptosis and has been shown to increase longevity in some experimental systems [242]. SIRT1 modulates poly (ADP-ribose) polymerase-1 (PARP-1) activity upon DNA damage. Activation of SIRT1 by resveratrol leads to a decrease in PARP-1 activity and promotes cell survival, which can attenuate the inflammatory reaction. We investigated the effects of resveratrol on human mast cell activation in comparison to the anti-allergic drug tranilast. The results show that resveratrol inhibits mast cell degranulation, cytokine, chemokine and leukotriene release, and is more efficacious than tranilast [316].

Resveratrol is able to modulate innate immune response by inhibiting expression of costimulatory molecules (CD80 and CD86) and major histocompatibility complex classes I and II in bone marrow-derived dendritic cells and inhibit angiogenesis pathway that is mediated through expression of MMPs, VEGF, cathepsin D, ICAM-1, and E-selectin [236]. These findings suggest that resveratrol can be a very attractive compound for preventing/treating asthma since this compound displays multiple therapeutic effects, showing antioxidative, antiinflammatory, immune modulating, and vascular protective property.

Resveratrol has been shown to inhibit the airway inflammation and hyperresponsiveness in OVA-induced mouse asthma by reducing eosinophil/neutrophils infiltration, the levels of IL-4 and IL-5 in plasma and BALF [81]. It can modulate Th1/Th2 balance, polarization of naive $\mathrm{CD}^{+} \mathrm{T}$ cells to the Th2 phenotype, and the expression of Th2 regulatory transcription factor, GATA-3 [81]. It also inhibits cytokine release in vitro by alveolar macrophages from patients with COPD, including IL-8 and GM-CSF [186]. 


\subsection{Selenium}

Selenium is an important molecule in both innate and adaptive immune responses. It stabilizes activated platelets by inhibiting platelet aggregation and secretion of adenine nucleotide, thus possibly blocking the release of acrachidonic acid from platelet membrane [243]. In asthma, platelets participate by acting as inflammatory cells, by releasing mediators, spasmogens and/ or by interacting with other inflammatory cell types [168]. Selenium affects the expression of endothelial cell adhesion molecules, E-selectin, P-selectin, ICAM-1, VCAM-1, and ELAM-1, which are crucial in the inflammatory process for recruitment of inflammatory cells into the target tissue [244].

Some studies have reported that asthma patients have lower selenium level in platelets and serum compared to healthy controls $[245,246]$. While others studies have found no relationship between serum selenium level and asthma in Japanese and Europe populations [247, 248]. Selenium supplementation studies in mouse OVA-induced asthma models have shown that selenium has some protective effects on asthma-associated inflammation. Mice with decreased and increased levels of selenium intake show lower cytokine levels, airway inflammatory cell infiltration, serum anti-OVA IgE, airway hyperreactivity, and phosphorylated STAT-6 levels in the lung compared to medium selenium intake [249]. Selenium supplementation does not show any clinical benefit in adult asthma patients [250].

Despite the data showing positive effects of selenium on some of the pathologies associated with asthma, there are still some conflicting findings of selenium supplementation in animal and human studies. Thus the issue regarding selenium is not conclusive.

\subsection{Avenanthramides}

Avenanthramides (Avns) are extracted from oats and those synthetically prepared exhibit potent antioxidant properties in vitro and in vivo. The antioxidant activity of Avns is 10-30 times greater than that of oats' other phenolic antioxidants such as vanillin and caffeic acid. Avn-C, one of the three major Avns of oats, often comprises about one-third of the total concentration of Avns in oat grain (although the relative proportion of Avns is highly variable), it has the highest antioxidant activity in vitro. By far, these Avns constitute the major phenolic antioxidants present in the oat kernel. The antioxidant activity of Avn-enriched extract of oats has been investigated in laboratory animals. Supplementing the diet of rats at $100 \mathrm{mg} / \mathrm{kg}$ diet (providing about $20 \mathrm{mg}$ Avns/kg body weight) has been reported to increase superoxide dismutase (SOD) activity in skeletal muscle, liver, and kidneys, and to enhance glutathione peroxidase activity in heart and skeletal muscles [251]. Supplementation at $200 \mathrm{mg} / \mathrm{kg}$ diet, which provides about $40 \mathrm{mg}$ Avns/kg body weight in rats, attenuated the exercise-induced production of ROS [251].

In addition to demonstrating antioxidant activity, Avn compounds may also interact with cellular components, through their interactions with the molecular and signaling pathways that govern cellular responses during inflammation. Using the human aortic endothelial cell (HAEC) culture system, the potentially beneficial health effects of oat Avns was found to be mediated via modulation of the cellular and molecular processes that are known to play an 
important role in the inflammation of arteries and the development of atherosclerosis [251]. They have been shown to inhibit vascular endothelial cell expression of adhesion molecules, including ICAM-1, VCAM-1, and E-selectin. Suppression of these adhesion molecules resulted in inhibition of monocyte adhesion to HAEC monolayers and reduced production of several inflammatory cytokines and chemokines, including IL-6, IL-8, and MCP-1, the inflammatory components involved in fatty streak formation in arteries. The production of proinflammatory cytokines, chemokines, and adhesion molecules by endothelial cells has been shown to be regulated by redox-sensitive signal transduction involving nuclear transcription factor NF- $\kappa \mathrm{B}$. The above-observed effects of Avns on HAEC and other cells are reported to be mediated through inhibition of NF- $\kappa B$. More recently, dihydroavenanthramide (DHAv), a synthetic analog of Avn, has been shown to protect pancreatic $\beta$-cells from damage via inhibition of NF$\kappa B$. In a series of experiments, Guo et al. determined that suppression of the expression of NF-

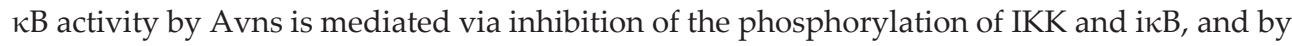
suppression of proteasome activity in endothelial cells [252]. A study by Sur et al. demonstrated anti-inflammatory activity of Avns in skin, inhibiting the degradation of I $\mathrm{kB}-\alpha$ in human keratinocytes which correlates with decreased activation of NF- $\kappa \mathrm{B}$ and subsequent reduction in IL-8 release [253]. Topical application mitigates skin inflammation in murine model of contact hypersensitivity and neurogenic inflammation and reduces pruritogen-induced scratching in murine itch model [253]. Taken together these observations suggest that Avns are potent anti-inflammatory agents with a potential application in asthma treatment.

\subsection{Herbal preparations}

Herbs have been used to treat airway diseases including asthma for thousands years in many nations, especially in Asian and African countries. In recent decades, some Chinese, Japanese, Indian, and African herbs have been tested for their anti-asthmatic effects.

\subsubsection{Boswellia serrata}

Boswellia serrata, Indian frankincense, is commonly found in many regions of the world, such as South Asia, Northern Africa, and Middle East. Traditional medicine using extract made from sap, has long been used to treat inflammatory diseases [204]. These extracts contain resin, amino acids, phenols, terpenes, polysaccharides [205] and $\beta$-boswellic acid the major active anti-inflammatory component [206].

Extract of Boswellia Serrata or $\beta$-boswellic acid has been reported to inhibit hypersensitivity reactions by regulating both the humoral and cellular immune systems They decrease primary antibody synthesis, inhibit polymorphonuclear leukocyte proliferation and infiltration, enhance the phagocytotic function of macrophages, and suppress the classical and alternate complement pathways [254, 255] and suppress the inflammation process, one of the critical pathological features in asthma. It has been shown that $\beta$-boswellic acid inhibits the production of proinflammatory cytokines, including TNF, IL-1, IL-2, IL-6, IL-12 and IFN- $\gamma$ by suppressing the activation of NF- $\kappa \mathrm{B}$ [256]. It also inhibits histamine release from mast cells challenged with $\mathrm{G}$ protein stimulator $\mathrm{c} 48 / 80$ in a dose-dependent manner [257]. $\beta$-boswellic acid can downregulate the synthesis of prostaglandins by inhibiting COX-1 in intact human platelets [258]. 
The synthesis of 5-hydroxyeicosatetraenoic acid (5-HETE) and leukotriene $\mathrm{B}_{4}$ from rat peritoneal polymorphonuclear leukocytes, which contribute to bronchoconstriction, and increased vascular permeability, are reduced by Boswellia Serrata extract as a result of 5-LO inhibition [259]. These results suggest that Boswellia Serrata might be effective in controlling the inflammation process and contraction of airway smooth muscle in asthmatic condition by inhibiting enzymes required for production of proinflammatory mediators and bronchoconstrictor.

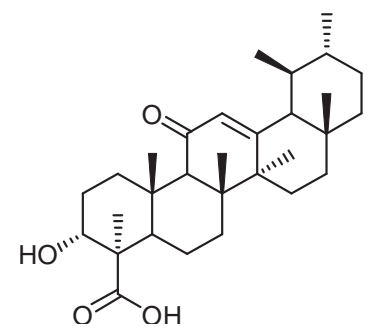

Boswellia serrata

Preliminary clinical investigation has shown Boswellia Serrata's potential therapeutic effect on asthma. In a double-blind, placebo-controlled clinical study [260], 40 patients took $300 \mathrm{mg}$ of extract daily for six weeks, while a control group received a lactose placebo for the same period of time. Lung and immune functions were recorded, including dyspnoea, rhonchi, frequency of attacks, FEV1, FVC, peak expiratory flow rate (PEFR), eosinophil count and erythrocyte sedimentation rate. In the treatment group $70 \%$ of patients and $27 \%$ in the control group showed improvement in terms of recorded physical symptoms and signs. These results suggest that Boswellia Serrata extract has potential benefit for asthma patients, although the age for control and treatment group was not perfectly matched. However, there is not enough evidence to draw a conclusion on the potential use of Boswellia Serrata for treating asthma in human.

\subsubsection{Bromelain}

Bromelain is an extract from the pineapple stem, Ananas comosus, containing a mixture of cysteine proteases, peroxidase, acid phosphatase, protease inhibitors, and calcium, with cysteine proteases being the main functional components [214].

Bromelain modulates immune responses both in vitro and in vivo. In vitro, it downregulates mRNA expression of IL-2, IL-4, and IFN- $\gamma$ in T cells induced by phorbol myristate acetate (PMA), with the mechanism thought to be the inhibitionof p21ras and subsequent ERK-2 [261, 262]. In a study using peripheral blood mononuclear cells (PBMC), Bromelain decreases the expression of migration/activation related cell surface markers on leukocyte by proteolysis, including CD14, CD16, CD21, CD25, CD44, CD45RA, CD62L [263]. In addition, it can dosedependently reduce CD25 expression in anti-CD3 antibody-stimulated CD4 ${ }^{+} \mathrm{T}$ cells, which is upregulated when T cells are activated in inflammation, autoimmunity and allergy [264]. 
These results indicate that Bromelain may regulate inflammatory process by interfering the migration and activation of immune cells, primarily T cells. In vivo, Bromelain may inhibit IgG production and decrease IL-2 gene transcription in spleen, and significantly reduce blood $\mathrm{CD}^{+}{ }^{+} \mathrm{T}$ cell count [262]. In addition, it downregulates IFN- $\gamma$ mRNA expression in spleen [265]. These results indicate that Bromelain has regulatory effects on the adaptive immunity, principally by targeting $\mathrm{T}$ cell responses.

Bromelain administration via intraperitoneal injection alleviates some of the features of airway inflammation in the OVA-induced murine asthma model. It reduces the total numbers of leukocytes, eosinophils, CD4 ${ }^{+}$and $\mathrm{CD}^{+} \mathrm{T}$ cells in BALF, and decreases IL-13 concentration, which is a critical mediator for AHR in asthma [266]. In separate study, oral supplementation has been shown to suppress airway methacholine sensitivity, decrease IL-13 level, and eosinophils, CD19+ B cells and CD8 ${ }^{+} \mathrm{T}$ cells counts in BAL [267]. These results suggest that Bromelain modulates airway reactivity by altering the presence of leukocytes in airway, which is consistent with the in vitro results mentioned above. However, there is no clinical report available on the use of Bromelain against asthma so far.

\subsubsection{Butterbur (Petasites hybridus)}

Butterbur is a member of the perennial sunflower family found in Europe and northern Asia. The ancient Greeks used butterbur roots to treat airway diseases and alleviate bronchial spasms [268].<smiles>C[C@](O)(Cc1ccc(O)c(O)c1)[C@H](OC(=O)/C=C/c1ccc(O)c(O)c1)C(=O)O</smiles>

Fukinolic acid<smiles>C=C(C)C1C[C@]2(C)C(CC[C@@H](OC(=O)/C(C)=C\C)[C@@H]2C)CC1=O</smiles>

Petasin

Extract from the flower bud, leaves and root have been shown to inhibit $\beta$-hexosaminidase release, leukotriene C4/D4/E4 synthesis, and TNF production from IgE-sensitized RBL-2H3 cell [223]. A group of Japanese researchers reported that Japanese butterbur contains multiple active compounds including two eremophilane-type sesquiterpenes, six polyphenolic compounds, and two triterpene glycosides [223], and based on its inhibitory activity on mast cell degranulation, fukinolic acid is believed to be the most active component [269]. Another active component petasin, can reduce leukotriene and ECP production from eosinophils activated 
by platelet-activating factor (PAF) or C5a via suppression of cytosolic phospholipase A2 (cPLA2) activity, decreasing intracellular calcium concentration and inhibiting 5-LO translocation from the cytosol to nuclear membrane [270]. Pepsin inhibits leukotriene production from macrophages [271] and suppresses bronchial constriction induced by histamine, carbachol, $\mathrm{KCl}$ and leukotriene $\mathrm{D}_{4}$ in isolated guinea pig trachea [272]. In the OVA murine model, butterbur extract given intranasally together with antigen challenge has been shown to inhibit airway inflammation induced by OVA and hyperresponsiveness to aerosolized methacholine, reduce eosinophil count and decrease Th2 cytokine production including IL-4, IL-5 and RANTES in BALF [227]. These results suggest that Butterbur may have inhibitory effects on proinflammatory mediator release from a broad range of immune cells.

In 2003, a prescription-based Butterbur extract was approved in Switzerland for the treatment of seasonal allergic rhinitis and in response some researchers have tested Butterbur extract for the treatment of asthma. Ziolo et al conducted an open clinical study on its effects on bronchial reactivity in asthma patients. Provided orally in a single dose for three time periods patients show significant improvement on FEV1, especially subjects those in longer treatment group[273]. In another randomized, double-blind, placebo-controlled clinical study, results have shown that the signs of asthma are significantly suppressed by Butterbur treatment including FEV1, exhaled NO, serum ECP and peripheral blood eosinophil count, suggesting Butterbur reduces some of the inflammatory markers associated with allergic respiratory inflammation [274], However, some long term adverse side effects have ben reported including abdominal pain, flatulence, and sneezing in pediatric patients and hair loss, cough, dyspnea, and severe depression for adult patients [230]. More studies with larger sample size are needed for the evaluation of Butterbur's clinical use on asthma.

\subsubsection{Curcumin}

Curcumin is a yellow polyphenol compound, extracted from the rhizomes of Curcuma longa [231]. In ancient time, curcumin containing turmeric plants were widely used to treat swelling and wounds in Southern Asia [275].<smiles>COc1cc(/C=C/C(=O)CC(=O)/C=C/c2ccc(O)c(C(C)=O)c2)ccc1O</smiles>

Curcumin

Many pharmacological effects of curcumin have been reported, including antioxidative, antiinflammatory and antimicrobial activities [276]. In terms of its antioxidative effects, curcumin is thought to be more potent than vitamin E [277] with the mechanism including downregulation of NO production, scavenging free radicals, and inducing heme oxygenase- 1 to repair the oxidative damage caused by free radicals [278-280]. Curcumin can inhibit the production of proinflammatory cytokines such as IL-1 $\beta$ and IL-8, suppress inducible iNOS and NO 
production, and modulate steroid activity. It's effect on steroid activity may be the result of inhibition of NF- $\kappa B$ through blocking IKK activity [281-284].

During allergic inflammation, curcumin may modulate both early and late phase responses by altering Th2 responses. In a murine latex-induced allergy model, characterized by an increased serum total $\mathrm{IgE}$ and latex specific $\mathrm{IgG}_{1}$, elevated peripheral blood eosinophils count, and enhanced lung tissue IL-4, IL-5 and IL-13, intragastric curcumin administration reduces lung inflammation. Protein expression of costimulatory molecules CD80, CD86, and OX40Ligand, and RNA expression of MMP-9, ornithine aminotransferase (OAT), and thymic stromal lymphopoietin (TSLP) in antigen-presenting cells are all decreased. These results suggest that curcumin may disrupt antigen presentation, so that has potential therapeutic value on allergen triggered airway inflammation [285].

Curcumin has been shown to have anti-asthmatic effects in both in vivo and in vitro studies. In OVA-induced asthma model in guinea pigs, curcumin treatment during OVA sensitization or following antigen challenge shows significant protective effects through attenuation of bronchial constriction and hyperreactivity [286]. This indicates curcumin has both preventive and therapeutic effects on asthma. In another study in an OVA-induced murine asthma model, curcumin's anti-asthmatic function is attributed to the suppression of iNOS and subsequent NO production, inhibition of inflammatory cytokine synthesis and downregulation of eosinophil recruitment to airway [91]. In vitro, curcumin supplementation inhibits IgE/antigen activation of mast cells through the principal activation pathway mediated by FceRI directly inhibiting Syk kinase phosphorylation, which is critical for the propagation of signaling cascade. Subsequently, the phosphorylation of MAP kinases including p38, ERK 1/2 and JNK are supressed, which are crucial for gene transcription and production of proinflammatory cytokines [287]. In addition, curcumin inhibits HDM-induced lymphocyte proliferation and production of IL-2, IL-4, IL-5, and GM-CSF by lymphocytes from asthma patients [246]. These results indicate that curcumin may attenuate asthma symptom by inhibiting production of cytokines related to eosinophil function and IgE synthesis, and suppressing IgE-mediated reactions and hyperreactivity.

\subsubsection{Licorice root (Glycyrrhiza glabra)}

Licorice root has been widely used around the world to treat cough since ancient time [247]. It contains the active compounds including glycyrrhizin, glycyrrhetinic acid, flavonoids, isoflavonoids, and chalcones [248]. Glycyrrhizin and glycyrrhetinic acid are considered to be the main active components [249] and are potent inhibitors of cortisol metabolism, due to their steroid like structures inhibiting the key steroid metabolic enzymes, delta 4-5-reductase, 11 beta-hydroxysteroid dehydrogenase and 20-hydroxysteroid dehydrogenase [250, 251]. Therefore, the benefits and side effects of steroid are both expected to be enhanced in the presence of glycyrrhetinic acid and glycyrrhizin. 


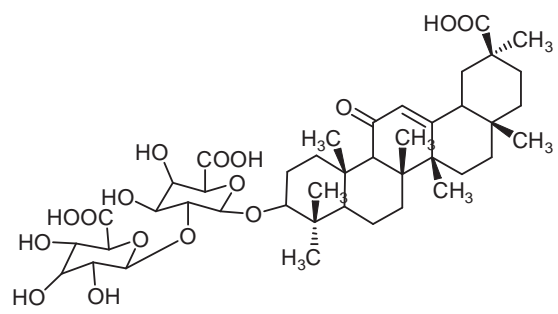

Glycyrrhizin<smiles>O=C1CC(c2ccc(O)cc2)Oc2cc(O)ccc21</smiles>

Liquiritige

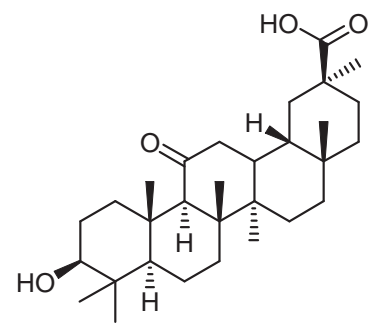

Glycyrrhetinic acid

The anti-inflammatory effect of glycyrrhizin during virus infection has been well documented [288-290] and may alleviate allergic inflammation as well. In a contact skin hypersensitivity mouse model, glycyrrhizin and its metabolite $18 \beta$-glycyrrhetinic acid-3-O- $\beta$-D-glucuronide show protective effects in terms of reduced passive cutaneous anaphylaxis and inflammation, with glycyrrhizin being more potent than $18 \beta$-glycyrrhetinic acid-3-O- $\beta$-D-glucuronide [291]. In an OVA-induced murine asthma model, glycyrrhizin provided orally alleviates airway constriction and hyperreactivity, pulmonary inflammation. In BAL, IFN $\gamma$ level is increased, while IL-4, IL-5 levels and eosinophil count are decreased. It also reduces OVA-specific IgE levels and upregulates total $\mathrm{IgG}_{2 \mathrm{a}}$ in serum as well [292]. These results indicate that glycyrrhizin interfere the production of $\operatorname{IgE}$ by decreasing the IgE-stimulating cytokines.

The effects of glycyrrhetinic acid and liquiritigenin (a flavonoid of licorice root) on asthma have been tested both in vivo and in vitro. In vitro, glycyrrhetinic acid and liquiritigenin inhibits $\beta$-hexosaminidase release from RBL-2H3 cells induced by IgE/DNP, and from rat peritoneal mast cells challenged with c48/80. In vivo, they can suppress c48/80 induced passive cutaneous anaphylactic reaction in mice. In OVA-induced murine asthma model, glycyrrhetinic acid but 
not liquiritigenin reduces the level of IgE in serum [293]. Flavonoids extracted from licorice root quench LPS-induced pulmonary inflammation by inhibiting the recruitment of neutrophils, macrophages and lymphocytes in BALF, and suppressing the mRNA expression of TNF and IL-1 $\beta$ in LPS-challenged lung tissue in mice [238]. The reported side effects of licorice root includes headache, hypertension, hypokalemia, premature birth, muscle weakness, and increase body weight, which were attributed to its function on inhibiting the steroid metabolism [294].

\subsubsection{Modified Mai-Men-Dong-Tang}

Mai-Men-Dong-Tang is an old Chinese herb formula commonly used for treating lung diseases, which contains Ophiopogon, Ginseng, Pinellia, Licorice, Jujube, and Oryza [260]. It is reported to increase the cough threshold to inhaled capsaicin in asthmatic patients. Also, the eosinophil count in peripheral blood, sputum eosinophil ratio, and serum eosinophil cationic protein level are significantly decreased, especially in patients with severe airway inflammation [261], which suggests that Mai-Men-Dong-Tang may alleviate asthma-related cough by inhibiting eosinophil function.

Modified Mai-Men-Dong-Tang (mMMDT) contains five herbs, Ophiopogon, American ginseng, Pinellia, Licorice root, and Lantern tridax [262]. The efficacy and safety of this formula to persistent, mild to moderate asthma has been evaluated in a double-blind, randomized clinical study of 100 patients with mild to moderate asthma. After 4 months, improvements in FEV1 and symptom scores has been reported in mMMDT treatment groups with decreased serum IgE and no drug-related adverse effects seen in terms of blood test, and liver, kidney functions [295]. Modified Mai-Men-Dong-Tang is a potential effective herb formula in treatment of childhood asthma for long time use. However, recommendation cannot be made because of small sample size used in the study.

\subsubsection{Ding-Chuan-Tang}

Ding-Chuan-Tang (DCT) is a traditional Chinese herb formula used for the treatment of cough, wheezing, and chest tightness, developed about four hundred years ago during the Ming dynasty. This formula contains nine herbs including Radix glycyrrhizae, Tuber pinellia, Gingko bilboae, Herba ephedrae, Flos tussilaginis farfarae, Cortex mori albae radicis, Fructus perilla frutescens, Semen pruni armeniacae, Radix scutellariae baicalensis [263]. In OVA-induced pig asthma model, DCT given orally to animals $30 \mathrm{~min}$ before antigen challenge inhibits the antigen induced immediate asthmatic responses. If it is given together with sensitization, immediate and late asthmatic responses are all suppressed. In addition, DCT relaxes trachea contracted with carbachol. The effects are attributed to decreased eosinophil infiltration to airway [263].

Randomized double-blind, placebo-controlled study to assess the effect of DCT on airway hyperreactivity in children with mild to moderate persistent asthma has shown that the FEV1 is significantly increased in DCT group (196\%, $\mathrm{p}=0.034)$, but not in placebo control group. Compared to placebo control group, total clinical/medication score shows improvement in the DCT group $(\mathrm{p}=0.004)$. No side effects have been reported [296]. These results suggest that DCT 
might be effective in treating asthma in children. Larger sample size and wider population are required in further investigations.

\subsubsection{STA-1 and STA-2}

STA is a combination of mMMDT and another Chinese herb formula Liu-Wei-Di-Huang-Wan (LWDHW), which is also used by Chinese as an anti-cough agent. LWDHW contains six herbs including Rehmannia root, Alisma rhizome, Dioscorea rhizome, Poria, Hoelen, Moutan root bark, Shanzhu yu. The formula for STA-1 and 2 are the same while the only difference being in the preparation of LWDHW is different [265]. In a mouse asthma model induced by intraperitoneally administrated dermatophagoides pteronyssinus group 5 allergen (Der p 5), oral STA-1 treatment during sensitization suppresses Der $\mathrm{p}$ 5-specific IgE production from animals in response to inhaled Der $\mathrm{p} 5$ challenge. In addition, eosinophil and neutrophil airway infiltration, and airway hyperreactivity are all significantly reduced in STA-1 group compared to control animals [266]. The efficacy and side effects of STA-1 and STA-2 on childhood asthma treatment have been evaluated in a randomized, double-blind, placebo-controlled study. The herbs and placebo provided to pediatric patients with mild to moderate asthma reduces symptom scores, serum steroid concentration, total IgE, and allergen-specific IgE levels and improves FEV1 in the STA-1 group. STA-2 does not show protective effects. No severe side effects were reported [297]. These results indicate that STA-1 might be a valuable formula for childhood asthma, especially subjects induced by dust mite antigen. However, there is not enough evidence to draw a concrete conclusion. It is worthwhile to evaluate their potential use as immunotherapy as well.

\subsubsection{Anti-Asthma Herbal Medicine Intervention (ASHMI)}

ASHMI is a relatively new formula developed by a group of Chinese researchers and physicians, which is an extract from three herbs: Radix glycyrrhizaen prednisone, Radix sophorae flavescentis, and Ganoderma [267]. In OVA-induced asthma, oral ASHMI treatment before and during OVA sensitization and challenge reduces AHR represented by time-integrated change in peak airway pressure. Eosinophil infiltration in BALF, lung inflammation, OVA-specific IgE production, and level of IL-4, IL-5, and IL-13 in lung and splenocyte cultures are significantly lower in ASHMI treated mice, whereas IFN- $\gamma$ production is increased [267, 268]. A 6-week treatment of ASHMI beginning $24 \mathrm{hr}$ after the first OVA challenge in mice reduces early phase response by decreasing histamine, leukotriene C, and OVA-specific IgE levels, and suppresses late phase responses by decreasing eosinophil count and Th2 cytokines in BALF. In addition, it relieves contraction of murine tracheal rings by increasing the production of $\mathrm{PGI}_{2}$ [269]. These results suggest that ASHMI inhibits asthmatic inflammation and airway muscle contraction, primarily by inhibiting Th2 cell function and might be suitable for treating antigen-induced asthma in both young and old subjects.

In clinical trial, ASHMI has been shown to improve lung function indicated by increased FEV1 and peak expiratory flow. Clinical symptom scores, use of $\beta 2$-bronchodilators, serum IgE level, serum IL-5, IL-13 concentrations are all reduced, and some effects are even better than prednisone. During the study no adverse effect were recorded [298]. These results indicate the 
effectiveness of ASHMI on treating asthma in both young and old adult patients. More adequately powered investigations are needed to evaluate ASHMI's effect on asthma.

\section{7. $n-3$ polyunsaturated fatty acids}

PUFA are a group of fatty acids with more than two carbon-carbon double bonds. There are three types of PUFA, n-3, n-6 and n-9, with their names based on the position of first double band from methyl end in their chemical structures. Currently, many studies have focused on n-3 and n-6 PUFA because EPA (20:4 n-3), Dihomo- $\gamma$-Linolenic acid (DGLA, 20:3 n-6) and Arachidonic acid (AA, 20:4 n-6) in cell membrane can be metabolized and become eicosanoid precursors, which are important modulatory autocrine molecules. Eicosanoids include prostaglandins, leukotrienes, thromboxanes, resolvins, lipoxins, are signal molecules that exert complex effects on health. They can modulate inflammation, fever, blood pressure, the immune system, etc. Eicosanoids can be made by oxidation of twenty carbon n-3 (EPA) and n-6 (DGLA, AA) PUFA. Eicosanoids from AA are proinflammatory, while those from EPA and DGLA are less so. There is competition between n-3 PUFA and n-6 PUFA in oxidation in terms of cyclooxygenase and lipoxygenase, which are critical enzymes for eicosanoid generation. AA is the predominant n-6 PUFA in body. In general, n-3 and n- 6 are hypothesized to be beneficial and detrimental respectively $[299,300]$. Fish, fish oil, krill, mussel and seal oil are natural sources of n-3 PUFA.

The major n-3 PUFA are listed in Table 12. In mammals, including humans, n-3 PUFA cannot be synthesized de novo. Therefore they must be absorbed through the diet or produced from $\alpha$-Linolenic acid (ALA), which is an essential fatty acid. Among them, the health beneficial effects of EPA and DHA (22:6n-3) are well documented in a broad range of health and disease conditions. The consumption of EPA and DHA are associated with lower risk of cancer, hyperlipidemia, and cardiovascular disease, high blood pressure, and neurodegenerative diseases [301-304]. Their regulating function on immune system was also well known and are involved in activation of immune cells like of T cells, B cells, mast cells and basophils [305, 306].

In recent decade, the relationship between n-3 PUFA and inflammatory diseases has been investigated in many studies. In a study conducted in rheumatoid arthritis patients, significant improvement in symptoms have been reported after 3 month fish oil supplementation in terms of tender joint count and duration of morning stiffness [307]. Besides reduction in the production of proinflammatory eicosanoids by competition with n-6 PUFA, n-3 PUFA has been found to be effective in inhibiting the synthesis of proinflammatory cytokines. In fat-1 transgenic mice, which have a much lower n-6:n-3 PUFA in tissues because they are genetically modified to possess the ability to convert n-6 PUFA to n-3 PUFA, serum proinflammatory cytokines, including TNF, IL-1 $\beta$, and IL-6 are lower. [280]. DHA and ALA also reduce the mRNA expression of IL-1 $\beta$, IL- 6 in a cerulein-induced pancreatitis model. They inhibit the activation of AP-1, suppress DNA fragmentation and decrease mRNA expression of apoptotic genes including p53, Bax and apoptosis-inducing factor in hydrogen peroxide-treated pancreatic acinar cells [308]. A randomized, double-blind human study has confirmed their suppressing effect on production of proinflammatory cytokines [309]. It has been shown that $n-3$ fatty acids 


\begin{tabular}{|c|c|c|c|c|}
\hline Common name & $\begin{array}{l}\text { Lipid } \\
\text { name }\end{array}$ & Chemical name & Formula/MW & Structure \\
\hline (HTA) & $\begin{array}{l}C 16: 3 \\
(n-3)\end{array}$ & $\begin{array}{l}\text { all-cis-7,10,13- } \\
\text { hexadecatrienoic acid }\end{array}$ & $\mathrm{C}_{16} \mathrm{H}_{26} \mathrm{O}_{2} / 250.376$ & \\
\hline $\begin{array}{l}\text { a-Linolenic } \\
\text { acid (ALA) }\end{array}$ & $\begin{array}{l}C 18: 3 \\
(n-3)\end{array}$ & $\begin{array}{l}\text { all-cis-9,12,15- } \\
\text { octadecatrienoic acid }\end{array}$ & $\mathrm{C}_{18} \mathrm{H}_{30} \mathrm{O}_{2} / 278.430$ & \\
\hline a-Parinaric acid & $\begin{array}{l}C 18: 4 \\
(n-3)\end{array}$ & $\begin{array}{l}\text { all-cis-9,11,13,15- } \\
\text { octadecatetraenoic acid }\end{array}$ & $\mathrm{C}_{18} \mathrm{H}_{28} \mathrm{O}_{2} / 276.414$ & \\
\hline $\begin{array}{l}\text { Stearidonic } \\
\text { acid (SDA) }\end{array}$ & $\begin{array}{l}C 18: 4(n \\
-3)\end{array}$ & $\begin{array}{l}\text { all-cis- } 6,9,12,15- \\
\text { octadecatetraenoic acid }\end{array}$ & $\mathrm{C}_{18} \mathrm{H}_{28} \mathrm{O}_{2} / 276.414$ & \\
\hline (ETE) & $\begin{array}{l}C 20: 3 \\
(n-3)\end{array}$ & $\begin{array}{l}\text { all-cis-11,14,17- } \\
\text { eicosatrienoic acid }\end{array}$ & $\mathrm{C}_{20} \mathrm{H}_{34} \mathrm{O}_{2} / 306.483$ & \\
\hline (ETA) & $\begin{array}{l}C 20: 4 \\
(n-3)\end{array}$ & $\begin{array}{l}\text { all-cis-8,11,14,17- } \\
\text { eicosatetraenoic acid }\end{array}$ & $\mathrm{C}_{20} \mathrm{H}_{32} \mathrm{O}_{2} / 304.467$ & \\
\hline (EPA) & $\begin{array}{l}C 20: 5 \\
(n-3)\end{array}$ & $\begin{array}{l}\text { all-cis-5,8,11,14,17- } \\
\text { eicosapentaenoic acid }\end{array}$ & $\mathrm{C}_{20} \mathrm{H}_{30} \mathrm{O}_{2} / 302.451$ & \\
\hline (DPA) & $\begin{array}{l}C 22: 5 \\
(n-3)\end{array}$ & $\begin{array}{l}\text { all-cis-7,10,13,16,19- } \\
\text { docosapentaenoic acid }\end{array}$ & $\mathrm{C}_{22} \mathrm{H}_{34} \mathrm{O}_{2} / 330.504$ & \\
\hline (DHA) & $\begin{array}{l}C 22: 6 \\
(n-3)\end{array}$ & $\begin{array}{l}\text { all-cis-4,7,10,13,16,19- } \\
\text { docosahexaenoic acid }\end{array}$ & $\mathrm{C}_{22} \mathrm{H}_{32} \mathrm{O}_{2} / 328.488$ & \\
\hline
\end{tabular}

Table 12. The common name, lipid name and chemical name of major n-3 PUFA

can alleviate inflammatory process by modulating cell signalling pathways in immune cells, such as T cell receptor pathway and cytokine receptor pathways. [310-312]

There have been a number of clinical studies that have shown n-3 PUFA's potentially protective effects on asthma, especially on childhood patients. There is a positive association between the n-6:n-3 PUFA in diet and risk for asthma [313]. A randomized, double-blind, placebocontrolled 3-year study on effect of n-3 PUFA supplementation on asthma has found that high n-3 PUFA diet intervention significantly reducesd the prevalence of cough in atopic children, suggesting that n-3 PUFA may be effective in preventing the development of asthma in early childhood [314]. In a cohort study on the relations between fish/cod oil intake and asthma, 
results have shown that adults with low fish intake frequency (less than weekly) have increased risk to have asthma [315]. Another randomized double-blind study with 5-weeks n-3 PUFA supplementation has reported a significant decrease in exhaled NO from asthma patients challenged with mite allergen. Serum eosinophils count and ECP, and the production of CysLTs from isolated leukocyte stimulated with mite antigen are also reduced [194]. Overall, n-3 PUFA might be a promising remedy agents for allergic diseases like asthma but the mechanism remains to be elucidated.

\section{Conclusion}

The prevalence of asthma is becoming the mortality and morbidity pandemic of the $21^{\text {st }}$ century. The cost of in quality of patient's lives and economic burden of treatment is continuing to grow at pace unmatched in our current health system. It is impossible to enter public classroom now without seeing a young sufferer of this condition and any trip to the emergency department will show how dangerous this disease can be. As the incidence and severity of the disease continues to rise, medical research is continuing to search new treatment strategies. While many treatments currently exists those reserve for the severest of conditions carry their own inherent risk which may match the severity of disease itself. It is for these reasons alone that health care professionals are now examining the traits of our ancestors in time when this epidemic was less severe to determine if their medicines and practices hold the answer for the next treatment strategy. By combining the scientific knowledge at the molecular and clinical level and the resources of past it might hold the answer to breathless pandemic of the $21^{\text {st }}$ century.

\section{Acknowledgements}

The authors are thankful to Dr. Clayton Macdonald for his assiatance with the manuscript preparation. This work is supported by the National Research Council Canada. Priyanka Pundir is the recipient of Innovation PEI Graduate Student Fellowship.

\section{Author details}

Priyanka Pundir ${ }^{1,2}$, Xiaofeng Wang ${ }^{1,2}$ and Marianna Kulka ${ }^{3}$

1 National Research Council Canada, Charlottetown, PE, Canada

2 Department of Biomedical Sciences, Atlantic Veterinary College, University of Prince Edward Island, Charlottetown, PE, Canada

3 National Research Council Canada, Edmonton, AB, Canada 


\section{References}

[1] Seaton A, Godden DJ, Brown K. Increase in asthma: a more toxic environment or a more susceptible population? Thorax. 1994;49(2):171-4. Epub 1994/02/01.

[2] Wood LG, Gibson PG, Garg ML. Biomarkers of lipid peroxidation, airway inflammation and asthma. Eur Respir J. 2003;21(1):177-86. Epub 2003/02/07.

[3] Katsumata U, Miura M, Ichinose M, Kimura K, Takahashi T, Inoue H, et al. Oxygen radicals produce airway constriction and hyperresponsiveness in anesthetized cats. The American review of respiratory disease. 1990;141(5 Pt 1):1158-61. Epub 1990/05/01.

[4] Rubin RN, Navon L, Cassano PA. Relationship of serum antioxidants to asthma prevalence in youth. Am J Respir Crit Care Med. 2004;169(3):393-8.

[5] Gilliland FD, Berhane KT, Li YF, Gauderman WJ, McConnell R, Peters J. Children's lung function and antioxidant vitamin, fruit, juice, and vegetable intake. Am J Epidemiol. 2003;158(6):576-84. Epub 2003/09/11.

[6] Hu G, Cassano PA. Antioxidant nutrients and pulmonary function: the Third National Health and Nutrition Examination Survey (NHANES III). Am J Epidemiol. 2000;151(10):975-81. Epub 2000/06/15.

[7] Britton JR, Pavord ID, Richards KA, Knox AJ, Wisniewski AF, Lewis SA, et al. Dietary antioxidant vitamin intake and lung function in the general population. Am J Respir Crit Care Med. 1995;151(5):1383-7. Epub 1995/05/01.

[8] Schwartz J, Weiss ST. Relationship between dietary vitamin C intake and pulmonary function in the First National Health and Nutrition Examination Survey (NHANES I). The American journal of clinical nutrition. 1994;59(1):110-4. Epub 1994/01/01.

[9] Soutar A, Seaton A, Brown K. Bronchial reactivity and dietary antioxidants. Thorax. 1997;52(2):166-70. Epub 1997/02/01.

[10] Harik-Khan RI, Muller DC, Wise RA. Serum vitamin levels and the risk of asthma in children. Am J Epidemiol. 2004;159(4):351-7.

[11] Bodner C, Godden D, Brown K, Little J, Ross S, Seaton A. Antioxidant intake and adult-onset wheeze: a case-control study. Aberdeen WHEASE Study Group. Eur Respir J. 1999;13(1):22-30. Epub 2000/06/03.

[12] Butland BK, Fehily AM, Elwood PC. Diet, lung function, and lung function decline in a cohort of 2512 middle aged men. Thorax. 2000;55(2):102-8. Epub 2000/01/20.

[13] Hijazi N, Abalkhail B, Seaton A. Diet and childhood asthma in a society in transition: a study in urban and rural Saudi Arabia. Thorax. 2000;55(9):775-9. Epub 2000/08/19. 
[14] Fogarty A, Lewis S, Weiss S, Britton J. Dietary vitamin E, IgE concentrations, and atopy. Lancet. 2000;356(9241):1573-4. Epub 2000/11/15.

[15] Butland BK, Strachan DP, Anderson HR. Fresh fruit intake and asthma symptoms in young British adults: confounding or effect modification by smoking? Eur Respir J. 1999;13(4):744-50. Epub 1999/06/11.

[16] Miedema I, Feskens EJ, Heederik D, Kromhout D. Dietary determinants of long-term incidence of chronic nonspecific lung diseases. The Zutphen Study. Am J Epidemiol. 1993;138(1):37-45. Epub 1993/07/01.

[17] Carey IM, Strachan DP, Cook DG. Effects of changes in fresh fruit consumption on ventilatory function in healthy British adults. Am J Respir Crit Care Med. 1998;158(3):728-33. Epub 1998/09/10.

[18] Shaheen SO, Sterne JA, Thompson RL, Songhurst CE, Margetts BM, Burney PG. Dietary antioxidants and asthma in adults: population-based case-control study. Am J Respir Crit Care Med. 2001;164(10 Pt 1):1823-8. Epub 2001/12/06.

[19] Dow L, Tracey M, Villar A, Coggon D, Margetts BM, Campbell MJ, et al. Does dietary intake of vitamins $C$ and $E$ influence lung function in older people? Am J Respir Crit Care Med. 1996;154(5):1401-4. Epub 1996/11/01.

[20] Morabia A, Sorenson A, Kumanyika SK, Abbey H, Cohen BH, Chee E. Vitamin A, cigarette smoking, and airway obstruction. The American review of respiratory disease. 1989;140(5):1312-6. Epub 1989/11/01.

[21] La Vecchia C, Decarli A, Pagano R. Vegetable consumption and risk of chronic disease. Epidemiology. 1998;9(2):208-10. Epub 1998/03/21.

[22] Ellwood P, Asher MI, Bjorksten B, Burr M, Pearce N, Robertson CF. Diet and asthma, allergic rhinoconjunctivitis and atopic eczema symptom prevalence: an ecological analysis of the International Study of Asthma and Allergies in Childhood (ISAAC) data. ISAAC Phase One Study Group. Eur Respir J. 2001;17(3):436-43. Epub 2001/06/19.

[23] Arts IC, Hollman PC. Polyphenols and disease risk in epidemiologic studies. The American journal of clinical nutrition. 2005;81(1 Suppl):317S-25S. Epub 2005/01/11.

[24] Barrett NA, Austen KF. Innate cells and T helper 2 cell immunity in airway inflammation. Immunity. 2009;31(3):425-37.

[25] Halwani R, Al-Muhsen S, Hamid Q. Airway remodeling in asthma. Curr Opin Pharmacol.10(3):236-45.

[26] Galli SJ, Tsai M, Piliponsky AM. The development of allergic inflammation. Nature. 2008;454(7203):445-54. Epub 2008/07/25.

[27] Holt PG. Antigen presentation in the lung. Am J Respir Crit Care Med. 2000;162(4 Pt 2):S151-6. 
[28] Willart MA, Hammad H. Alarming dendritic cells for allergic sensitization. Allergol Int.59(2):95-103.

[29] Robinson DS. The role of the T cell in asthma. J Allergy Clin Immunol.126(6):1081-91; quiz 92-3.

[30] Holgate ST. Pathogenesis of asthma. Clin Exp Allergy. 2008;38(6):872-97.

[31] Fox B, Bull TB, Guz A. Mast cells in the human alveolar wall: an electronmicroscopic study. J Clin Pathol. 1981;34(12):1333-42.

[32] Rivera J, Fierro NA, Olivera A, Suzuki R. New insights on mast cell activation via the high affinity receptor for IgE. Adv Immunol. 2008;98:85-120.

[33] Pundir P, Kulka M. The role of G protein-coupled receptors in mast cell activation by antimicrobial peptides: is there a connection? Immunol Cell Biol.88(6):632-40.

[34] Pradalier A. Late-phase reaction in asthma: basic mechanisms. Int Arch Allergy Immunol. 1993;101(3):322-5.

[35] Bradding P, Holgate ST. Immunopathology and human mast cell cytokines. Crit Rev Oncol Hematol. 1999;31(2):119-33.

[36] Leckie MJ, ten Brinke A, Khan J, Diamant Z, O'Connor BJ, Walls CM, et al. Effects of an interleukin-5 blocking monoclonal antibody on eosinophils, airway hyper-responsiveness, and the late asthmatic response. Lancet. 2000;356(9248):2144-8.

[37] Larsen GL, Wilson MC, Clark RA, Behrens BL. The inflammatory reaction in the airways in an animal model of the late asthmatic response. Fed Proc. 1987;46(1):105-12.

[38] De Monchy JG, Kauffman HF, Venge P, Koeter GH, Jansen HM, Sluiter HJ, et al. Bronchoalveolar eosinophilia during allergen-induced late asthmatic reactions. Am Rev Respir Dis. 1985;131(3):373-6.

[39] Kariyawasam HH, Robinson DS. The eosinophil: the cell and its weapons, the cytokines, its locations. Semin Respir Crit Care Med. 2006;27(2):117-27.

[40] Panettieri RA, Tan EM, Ciocca V, Luttmann MA, Leonard TB, Hay DW. Effects of LTD4 on human airway smooth muscle cell proliferation, matrix expression, and contraction In vitro: differential sensitivity to cysteinyl leukotriene receptor antagonists. Am J Respir Cell Mol Biol. 1998;19(3):453-61.

[41] Laitinen LA, Laitinen A, Haahtela T, Vilkka V, Spur BW, Lee TH. Leukotriene E4 and granulocytic infiltration into asthmatic airways. Lancet. 1993;341(8851):989-90. Epub 1993/04/17.

[42] Sur S, Crotty TB, Kephart GM, Hyma BA, Colby TV, Reed CE, et al. Sudden-onset fatal asthma. A distinct entity with few eosinophils and relatively more neutrophils in the airway submucosa? The American review of respiratory disease. 1993;148(3): 713-9. Epub 1993/09/01. 
[43] Fahy JV, Kim KW, Liu J, Boushey HA. Prominent neutrophilic inflammation in sputum from subjects with asthma exacerbation. J Allergy Clin Immunol. 1995;95(4): 843-52. Epub 1995/04/01.

[44] Hamzaoui A, Hamzaoui K, Salah H, Chabbou A. Lymphocytes apoptosis in patients with acute exacerbation of asthma. Mediators of inflammation. 1999;8(4-5):237-43. Epub 2000/03/07.

[45] Robinson D, Hamid Q, Bentley A, Ying S, Kay AB, Durham SR. Activation of CD4+ T cells, increased TH2-type cytokine mRNA expression, and eosinophil recruitment in bronchoalveolar lavage after allergen inhalation challenge in patients with atopic asthma. J Allergy Clin Immunol. 1993;92(2):313-24. Epub 1993/08/01.

[46] Cumming RG, Mitchell P, Leeder SR. Use of inhaled corticosteroids and the risk of cataracts. The New England journal of medicine. 1997;337(1):8-14. Epub 1997/07/03.

[47] van Staa TP, Leufkens HG, Cooper C. Use of inhaled corticosteroids and risk of fractures. Journal of bone and mineral research : the official journal of the American Society for Bone and Mineral Research. 2001;16(3):581-8. Epub 2001/03/30.

[48] Guilbert TW, Morgan WJ, Zeiger RS, Mauger DT, Boehmer SJ, Szefler SJ, et al. Longterm inhaled corticosteroids in preschool children at high risk for asthma. The New England journal of medicine. 2006;354(19):1985-97. Epub 2006/05/12.

[49] Lou HQ, Ying YF, Hu Y. [CRTH2 antagonist ameliorates airway inflammation in rats with asthma]. Zhejiang Da Xue Xue Bao Yi Xue Ban.39(1):64-70.

[50] Lukacs NW, Berlin AA, Franz-Bacon K, Sasik R, Sprague LJ, Ly TW, et al. CRTH2 antagonism significantly ameliorates airway hyperreactivity and downregulates inflammation-induced genes in a mouse model of airway inflammation. Am J Physiol Lung Cell Mol Physiol. 2008;295(5):L767-79.

[51] Hicks A, Goodnow R, Jr., Cavallo G, Tannu SA, Ventre JD, Lavelle D, et al. Effects of LTB4 receptor antagonism on pulmonary inflammation in rodents and non-human primates. Prostaglandins Other Lipid Mediat.92(1-4):33-43.

[52] Kimata M, Shichijo M, Miura T, Serizawa I, Inagaki N, Nagai H. Effects of luteolin, quercetin and baicalein on immunoglobulin E-mediated mediator release from human cultured mast cells. Clin Exp Allergy. 2000;30(4):501-8.

[53] Siegle JS, Hansbro N, Dong C, Angkasekwinai P, Foster PS, Kumar RK. Blocking induction of T helper type 2 responses prevents development of disease in a model of childhood asthma. Clin Exp Immunol.

[54] Caramori G, Groneberg D, Ito K, Casolari P, Adcock IM, Papi A. New drugs targeting Th2 lymphocytes in asthma. J Occup Med Toxicol. 2008;3 Suppl 1:S6. Epub 2008/03/05. 
[55] Rosenwasser LJ, Rothenberg ME. IL-5 pathway inhibition in the treatment of asthma and Churg-Strauss syndrome. J Allergy Clin Immunol.125(6):1245-6.

[56] Walsh GM. Tralokinumab, an anti-IL-13 mAb for the potential treatment of asthma and COPD. Curr Opin Investig Drugs.11(11):1305-12.

[57] Hirano T, Higa S, Arimitsu J, Naka T, Shima Y, Ohshima S, et al. Flavonoids such as luteolin, fisetin and apigenin are inhibitors of interleukin-4 and interleukin-13 production by activated human basophils. Int Arch Allergy Immunol. 2004;134(2): $135-40$.

[58] Kang OH, Lee JH, Kwon DY. Apigenin inhibits release of inflammatory mediators by blocking the NF-kappaB activation pathways in the HMC-1 cells. Immunopharmacol Immunotoxicol.

[59] Hsieh CJ, Hall K, Ha T, Li C, Krishnaswamy G, Chi DS. Baicalein inhibits IL-1betaand TNF-alpha-induced inflammatory cytokine production from human mast cells via regulation of the NF-kappaB pathway. Clin Mol Allergy. 2007;5:5.

[60] Lixuan Z, Jingcheng D, Wenqin Y, Jianhua H, Baojun L, Xiaotao F. Baicalin attenuates inflammation by inhibiting NF-kappaB activation in cigarette smoke induced inflammatory models. Pulm Pharmacol Ther.23(5):411-9.

[61] Bae Y, Lee S, Kim SH. Chrysin suppresses mast cell-mediated allergic inflammation: Involvement of calcium, caspase-1 and nuclear factor-kappaB. Toxicol Appl Pharmacol.254(1):56-64.

[62] Nakamura R, Nakamura R, Watanabe K, Oka K, Ohta S, Mishima S, et al. Effects of propolis from different areas on mast cell degranulation and identification of the effective components in propolis. Int Immunopharmacol.10(9):1107-12.

[63] Higa S, Hirano T, Kotani M, Matsumoto M, Fujita A, Suemura M, et al. Fisetin, a flavonol, inhibits TH2-type cytokine production by activated human basophils. J Allergy Clin Immunol. 2003;111(6):1299-306.

[64] Weseler AR, Geraets L, Moonen HJ, Manders RJ, van Loon LJ, Pennings HJ, et al. Poly (ADP-ribose) polymerase-1-inhibiting flavonoids attenuate cytokine release in blood from male patients with chronic obstructive pulmonary disease or type 2 diabetes. J Nutr. 2009;139(5):952-7.

[65] Park HH, Lee S, Oh JM, Lee MS, Yoon KH, Park BH, et al. Anti-inflammatory activity of fisetin in human mast cells (HMC-1). Pharmacol Res. 2007;55(1):31-7.

[66] Han JM, Jin YY, Kim HY, Park KH, Lee WS, Jeong TS. Lavandulyl flavonoids from Sophora flavescens suppress lipopolysaccharide-induced activation of nuclear factorkappaB and mitogen-activated protein kinases in RAW264.7 cells. Biol Pharm Bull. 33(6):1019-23.

[67] Park CM, Jin KS, Lee YW, Song YS. Luteolin and chicoric acid synergistically inhibited inflammatory responses via inactivation of PI3K-Akt pathway and impairment of 
NF-kappaB translocation in LPS stimulated RAW 264.7 cells. Eur J Pharmacol. 660(2-3):454-9.

[68] Kang OH, Jang HJ, Chae HS, Oh YC, Choi JG, Lee YS, et al. Anti-inflammatory mechanisms of resveratrol in activated HMC-1 cells: pivotal roles of NF-kappaB and MAPK. Pharmacol Res. 2009;59(5):330-7.

[69] Jin M, Yang JH, Lee E, Lu Y, Kwon S, Son KH, et al. Antiasthmatic activity of luteolin-7-O-glucoside from Ailanthus altissima through the downregulation of T helper 2 cytokine expression and inhibition of prostaglandin E2 production in an ovalbumininduced asthma model. Biol Pharm Bull. 2009;32(9):1500-3.

[70] Kempuraj D, Tagen M, Iliopoulou BP, Clemons A, Vasiadi M, Boucher W, et al. Luteolin inhibits myelin basic protein-induced human mast cell activation and mast cell-dependent stimulation of Jurkat T cells. Br J Pharmacol. 2008;155(7):1076-84.

[71] Hougee S, Sanders A, Faber J, Graus YM, van den Berg WB, Garssen J, et al. Decreased pro-inflammatory cytokine production by LPS-stimulated PBMC upon in vitro incubation with the flavonoids apigenin, luteolin or chrysin, due to selective elimination of monocytes/macrophages. Biochem Pharmacol. 2005;69(2):241-8.

[72] Das M, Ram A, Ghosh B. Luteolin alleviates bronchoconstriction and airway hyperreactivity in ovalbumin sensitized mice. Inflamm Res. 2003;52(3):101-6.

[73] Mastuda H, Morikawa T, Ueda K, Managi H, Yoshikawa M. Structural requirements of flavonoids for inhibition of antigen-Induced degranulation, TNF-alpha and IL-4 production from RBL-2H3 cells. Bioorg Med Chem. 2002;10(10):3123-8.

[74] Harasstani OA, Moin S, Tham CL, Liew CY, Ismail N, Rajajendram R, et al. Flavonoid combinations cause synergistic inhibition of proinflammatory mediator secretion from lipopolysaccharide-induced RAW 264.7 cells. Inflamm Res.59(9):711-21.

[75] Kempuraj D, Madhappan B, Christodoulou S, Boucher W, Cao J, Papadopoulou N, et al. Flavonols inhibit proinflammatory mediator release, intracellular calcium ion levels and protein kinase C theta phosphorylation in human mast cells. Br J Pharmacol. 2005;145(7):934-44.

[76] Park HH, Lee S, Son HY, Park SB, Kim MS, Choi EJ, et al. Flavonoids inhibit histamine release and expression of proinflammatory cytokines in mast cells. Arch Pharm Res. 2008;31(10):1303-11.

[77] Iwamura C, Shinoda K, Yoshimura M, Watanabe Y, Obata A, Nakayama T. Naringenin chalcone suppresses allergic asthma by inhibiting the type-2 function of CD4 T cells. Allergol Int.59(1):67-73.

[78] Shi Y, Dai J, Liu H, Li RR, Sun PL, Du Q, et al. Naringenin inhibits allergen-induced airway inflammation and airway responsiveness and inhibits NF-kappaB activity in a murine model of asthma. Can J Physiol Pharmacol. 2009;87(9):729-35. 
[79] Bodet C, La VD, Epifano F, Grenier D. Naringenin has anti-inflammatory properties in macrophage and ex vivo human whole-blood models. J Periodontal Res. 2008;43(4):400-7.

[80] Rao YK, Fang SH, Hsieh SC, Yeh TH, Tzeng YM. The constituents of Anisomeles indica and their anti-inflammatory activities. J Ethnopharmacol. 2009;121(2):292-6.

[81] Lee M, Kim S, Kwon OK, Oh SR, Lee HK, Ahn K. Anti-inflammatory and anti-asthmatic effects of resveratrol, a polyphenolic stilbene, in a mouse model of allergic asthma. Int Immunopharmacol. 2009;9(4):418-24.

[82] Knobloch J, Sibbing B, Jungck D, Lin Y, Urban K, Stoelben E, et al. Resveratrol impairs the release of steroid-resistant inflammatory cytokines from human airway smooth muscle cells in chronic obstructive pulmonary disease. J Pharmacol Exp Ther.335(3):788-98.

[83] Oh YC, Kang OH, Choi JG, Chae HS, Lee YS, Brice OO, et al. Anti-inflammatory effect of resveratrol by inhibition of IL-8 production in LPS-induced THP-1 cells. Am J Chin Med. 2009;37(6):1203-14.

[84] Bereswill S, Munoz M, Fischer A, Plickert R, Haag LM, Otto B, et al. Anti-inflammatory effects of resveratrol, curcumin and simvastatin in acute small intestinal inflammation. PLoS One.5(12):e15099.

[85] Cao Q, Jing C, Tang X, Yin Y, Han X, Wu W. Protective effect of resveratrol on acute lung injury induced by lipopolysaccharide in mice. Anat Rec (Hoboken).294(3): 527-32.

[86] Issuree PD, Pushparaj PN, Pervaiz S, Melendez AJ. Resveratrol attenuates C5a-induced inflammatory responses in vitro and in vivo by inhibiting phospholipase D and sphingosine kinase activities. Faseb J. 2009;23(8):2412-24.

[87] Kuo FH, Jan TR. Silibinin attenuates antigen-specific IgE production through the modulation of Th1/Th2 balance in ovalbumin-sensitized BALB/c mice. Phytomedicine. 2009;16(2-3):271-6.

[88] Jung WK, Lee DY, Choi YH, Yea SS, Choi I, Park SG, et al. Caffeic acid phenethyl ester attenuates allergic airway inflammation and hyperresponsiveness in murine model of ovalbumin-induced asthma. Life Sci. 2008;82(13-14):797-805.

[89] Wang LC, Lin YL, Liang YC, Yang YH, Lee JH, Yu HH, et al. The effect of caffeic acid phenethyl ester on the functions of human monocyte-derived dendritic cells. BMC Immunol. 2009;10:39.

[90] Khayyal MT, el-Ghazaly MA, el-Khatib AS, Hatem AM, de Vries PJ, el-Shafei S, et al. A clinical pharmacological study of the potential beneficial effects of a propolis food product as an adjuvant in asthmatic patients. Fundam Clin Pharmacol. 2003;17(1): 93-102. 
[91] Moon DO, Kim MO, Lee HJ, Choi YH, Park YM, Heo MS, et al. Curcumin attenuates ovalbumin-induced airway inflammation by regulating nitric oxide. Biochem Biophys Res Commun. 2008;375(2):275-9.

[92] Wong CK, Li ML, Wang CB, Ip WK, Tian YP, Lam CW. House dust mite allergen Der $\mathrm{p} 1$ elevates the release of inflammatory cytokines and expression of adhesion molecules in co-culture of human eosinophils and bronchial epithelial cells. Int Immunol. 2006;18(8):1327-35.

[93] Kobayashi T, Hashimoto S, Horie T. Curcumin inhibition of Dermatophagoides farinea-induced interleukin-5 (IL-5) and granulocyte macrophage-colony stimulating factor (GM-CSF) production by lymphocytes from bronchial asthmatics. Biochem Pharmacol. 1997;54(7):819-24.

[94] Baek OS, Kang OH, Choi YA, Choi SC, Kim TH, Nah YH, et al. Curcumin inhibits protease-activated receptor-2 and -4-mediated mast cell activation. Clin Chim Acta. 2003;338(1-2):135-41.

[95] Temkin V, Kantor B, Weg V, Hartman ML, Levi-Schaffer F. Tryptase activates the mitogen-activated protein kinase/activator protein-1 pathway in human peripheral blood eosinophils, causing cytokine production and release. J Immunol. 2002;169(5): 2662-9.

[96] Bani D, Giannini L, Ciampa A, Masini E, Suzuki Y, Menegazzi M, et al. Epigallocatechin-3-gallate reduces allergen-induced asthma-like reaction in sensitized guinea pigs. J Pharmacol Exp Ther. 2006;317(3):1002-11.

[97] Shin HY, Kim SH, Jeong HJ, Kim SY, Shin TY, Um JY, et al. Epigallocatechin-3-gallate inhibits secretion of TNF-alpha, IL-6 and IL-8 through the attenuation of ERK and NF-kappaB in HMC-1 cells. Int Arch Allergy Immunol. 2007;142(4):335-44.

[98] Syed DN, Afaq F, Kweon MH, Hadi N, Bhatia N, Spiegelman VS, et al. Green tea polyphenol EGCG suppresses cigarette smoke condensate-induced NF-kappaB activation in normal human bronchial epithelial cells. Oncogene. 2007;26(5):673-82.

[99] Bae HB, Li M, Kim JP, Kim SJ, Jeong CW, Lee HG, et al. The effect of epigallocatechin gallate on lipopolysaccharide-induced acute lung injury in a murine model. Inflammation.33(2):82-91.

[100] Rodrigues TG, Fernandes A, Jr., Sousa JP, Bastos JK, Sforcin JM. In vitro and in vivo effects of clove on pro-inflammatory cytokines production by macrophages. Nat Prod Res. 2009;23(4):319-26.

[101] Adhami VM, Malik A, Zaman N, Sarfaraz S, Siddiqui IA, Syed DN, et al. Combined inhibitory effects of green tea polyphenols and selective cyclooxygenase-2 inhibitors on the growth of human prostate cancer cells both in vitro and in vivo. Clin Cancer Res. 2007;13(5):1611-9. 
[102] Kim SH, Jun CD, Suk K, Choi BJ, Lim H, Park S, et al. Gallic acid inhibits histamine release and pro-inflammatory cytokine production in mast cells. Toxicol Sci. 2006;91(1):123-31.

[103] Tripathi S, Maier KG, Bruch D, Kittur DS. Effect of 6-gingerol on pro-inflammatory cytokine production and costimulatory molecule expression in murine peritoneal macrophages. J Surg Res. 2007;138(2):209-13.

[104] Zhang X, Cao J, Zhong L. Hydroxytyrosol inhibits pro-inflammatory cytokines, iNOS, and COX-2 expression in human monocytic cells. Naunyn Schmiedebergs Arch Pharmacol. 2009;379(6):581-6.

[105] Bitler CM, Viale TM, Damaj B, Crea R. Hydrolyzed olive vegetation water in mice has anti-inflammatory activity. J Nutr. 2005;135(6):1475-9.

[106] Inoue K, Takano H, Shiga A, Fujita Y, Makino H, Yanagisawa R, et al. Effects of volatile constituents of a rosemary extract on allergic airway inflammation related to house dust mite allergen in mice. Int J Mol Med. 2005;16(2):315-9.

[107] Sanbongi C, Takano H, Osakabe N, Sasa N, Natsume M, Yanagisawa R, et al. Rosmarinic acid in perilla extract inhibits allergic inflammation induced by mite allergen, in a mouse model. Clin Exp Allergy. 2004;34(6):971-7.

[108] Oh HA, Park CS, Ahn HJ, Park YS, Kim HM. Effect of Perilla frutescens var. acuta Kudo and rosmarinic acid on allergic inflammatory reactions. Exp Biol Med (Maywood).236(1):99-106.

[109] Jang AH, Kim TH, Kim GD, Kim JE, Kim HJ, Kim SS, et al. Rosmarinic acid attenuates 2,4-dinitrofluorobenzene-induced atopic dermatitis in NC/Nga mice. Int Immunopharmacol.

[110] Inoue K, Takano H, Shiga A, Fujita Y, Makino H, Yanagisawa R, et al. Effects of volatile constituents of rosemary extract on lung inflammation induced by diesel exhaust particles. Basic Clin Pharmacol Toxicol. 2006;99(1):52-7.

[111] Pae HO, Jeong GS, Kim HS, Woo WH, Rhew HY, Kim HS, et al. Costunolide inhibits production of tumor necrosis factor-alpha and interleukin- 6 by inducing heme oxygenase-1 in RAW264.7 macrophages. Inflamm Res. 2007;56(12):520-6.

[112] Kang JS, Yoon YD, Lee KH, Park SK, Kim HM. Costunolide inhibits interleukin-1beta expression by down-regulation of AP-1 and MAPK activity in LPS-stimulated RAW 264.7 cells. Biochem Biophys Res Commun. 2004;313(1):171-7.

[113] Seidel P, Merfort I, Hughes JM, Oliver BG, Tamm M, Roth M. Dimethylfumarate inhibits NF-\{kappa\}B function at multiple levels to limit airway smooth muscle cell cytokine secretion. Am J Physiol Lung Cell Mol Physiol. 2009;297(2):L326-39.

[114] Ben S, Li X, Xu F, Xu W, Li W, Wu Z, et al. Treatment with anti-CC chemokine receptor 3 monoclonal antibody or dexamethasone inhibits the migration and differentia- 
tion of bone marrow CD34 progenitor cells in an allergic mouse model. Allergy. 2008;63(9):1164-76.

[115] Das AM, Vaddi KG, Solomon KA, Krauthauser C, Jiang X, McIntyre KW, et al. Selective inhibition of eosinophil influx into the lung by small molecule CC chemokine receptor 3 antagonists in mouse models of allergic inflammation. J Pharmacol Exp Ther. 2006;318(1):411-7.

[116] Nakagami Y, Kawase Y, Yonekubo K, Nosaka E, Etori M, Takahashi S, et al. RS-1748, a novel CC chemokine receptor 4 antagonist, inhibits ovalbumin-induced airway inflammation in guinea pigs. Biol Pharm Bull.33(6):1067-9.

[117] Vijayanand P, Durkin K, Hartmann G, Morjaria J, Seumois G, Staples KJ, et al. Chemokine receptor 4 plays a key role in $\mathrm{T}$ cell recruitment into the airways of asthmatic patients. J Immunol.184(8):4568-74.

[118] Sugimoto H, Shichijo M, Iino T, Manabe Y, Watanabe A, Shimazaki M, et al. An orally bioavailable small molecule antagonist of CRTH2, ramatroban (BAY u3405), inhibits prostaglandin D2-induced eosinophil migration in vitro. J Pharmacol Exp Ther. 2003;305(1):347-52.

[119] Uller L, Mathiesen JM, Alenmyr L, Korsgren M, Ulven T, Hogberg T, et al. Antagonism of the prostaglandin D2 receptor CRTH2 attenuates asthma pathology in mouse eosinophilic airway inflammation. Respir Res. 2007;8:16.

[120] Huang CH, Kuo PL, Hsu YL, Chang TT, Tseng HI, Chu YT, et al. The natural flavonoid apigenin suppresses Th1- and Th2-related chemokine production by human monocyte THP-1 cells through mitogen-activated protein kinase pathways. J Med Food.13(2):391-8.

[121] Kowalski J, Samojedny A, Paul M, Pietsz G. [Apigenin inhibits release and gene expression of monocyte chemoattractant protein 1 (MCP-1) in J774.2 macrophages]. Wiad Lek. 2006;59(9-10):634-8. Hamujacy wplyw apigeniny na wydzielanie i ekspresji genu bialka chemotaktycznego monocytow (MCP-1) w hodowli makrofagow linii J774.2.

[122] Nakajima T, Imanishi M, Yamamoto K, Cyong JC, Hirai K. Inhibitory effect of baicalein, a flavonoid in Scutellaria Root, on eotaxin production by human dermal fibroblasts. Planta Med. 2001;67(2):132-5.

[123] Lee S, Kim YJ, Kwon S, Lee Y, Choi SY, Park J, et al. Inhibitory effects of flavonoids on TNF-alpha-induced IL-8 gene expression in HEK 293 cells. BMB Rep. 2009;42(5): $265-70$.

[124] Sohn MH, Lee KE, Kim KW, Kim ES, Park JY, Kim KE. Calcium-calmodulin mediates house dust mite-induced ERK activation and IL-8 production in human respiratory epithelial cells. Respiration. 2007;74(4):447-53.

[125] Trompezinski S, Denis A, Schmitt D, Viac J. Comparative effects of polyphenols from green tea (EGCG) and soybean (genistein) on VEGF and IL-8 release from normal hu- 
man keratinocytes stimulated with the proinflammatory cytokine TNFalpha. Arch Dermatol Res. 2003;295(3):112-6.

[126] Saito N, Yamada Y, Sannohe S, Honda K, Adachi T, Kayaba H, et al. Possible involvement of $\mathrm{C}-\mathrm{C}$ chemokines in functional augmentation of adhesion molecules in asthmatic patients. Lung. 2002;180(5):251-63.

[127] Jayaprakasam B, Doddaga S, Wang R, Holmes D, Goldfarb J, Li XM. Licorice flavonoids inhibit eotaxin-1 secretion by human fetal lung fibroblasts in vitro. J Agric Food Chem. 2009;57(3):820-5.

[128] Huang CH, Jan RL, Kuo CH, Chu YT, Wang WL, Lee MS, et al. Natural Flavone Kaempferol Suppresses Chemokines Expression in Human Monocyte THP-1 Cells through MAPK Pathways. J Food Sci.75(8):H254-H9.

[129] Kowalski J, Samojedny A, Paul M, Pietsz G, Wilczok T. Effect of kaempferol on the production and gene expression of monocyte chemoattractant protein-1 in J774.2 macrophages. Pharmacol Rep. 2005;57(1):107-12.

[130] Lee SW, Lee HS, Nam JY, Kwon OE, Baek JA, Chang JS, et al. Kurarinone isolated from Sophora flavescens Ait inhibited MCP-1-induced chemotaxis. J Ethnopharmacol. 2005;97(3):515-9.

[131] Funakoshi-Tago M, Nakamura K, Tago K, Mashino T, Kasahara T. Anti-inflammatory activity of structurally related flavonoids, Apigenin, Luteolin and Fisetin. Int Immunopharmacol.

[132] Kang OH, Choi JG, Lee JH, Kwon DY. Luteolin isolated from the flowers of Lonicera japonica suppresses inflammatory mediator release by blocking NF-kappaB and MAPKs activation pathways in HMC-1 cells. Molecules.15(1):385-98.

[133] Yeh SL, Wang HM, Chen PY, Wu TC. Interactions of beta-carotene and flavonoids on the secretion of pro-inflammatory mediators in an in vitro system. Chem Biol Interact. 2009;179(2-3):386-93.

[134] Min YD, Choi CH, Bark H, Son HY, Park HH, Lee S, et al. Quercetin inhibits expression of inflammatory cytokines through attenuation of NF-kappaB and p38 MAPK in HMC-1 human mast cell line. Inflamm Res. 2007;56(5):210-5.

[135] Castellani ML, Kempuraj D, Frydas S, Theoharides TC, Simeonidou I, Conti P, et al. Inhibitory effect of quercetin on tryptase and MCP-1 chemokine release, and histidine decarboxylase mRNA transcription by human mast cell-1 cell line. Neuroimmunomodulation. 2006;13(3):179-86.

[136] Nanua S, Zick SM, Andrade JE, Sajjan US, Burgess JR, Lukacs NW, et al. Quercetin blocks airway epithelial cell chemokine expression. Am J Respir Cell Mol Biol. 2006;35(5):602-10.

[137] Chung EY, Roh E, Kwak JA, Lee HS, Lee SH, Lee CK, et al. alpha-Viniferin suppresses the signal transducer and activation of transcription-1 (STAT-1)-inducible inflam- 
matory genes in interferon-gamma-stimulated macrophages. J Pharmacol Sci.112(4): 405-14.

[138] Wang J, Zhang Y, Yang C, Hou M, Wang F, Wang G, et al. [Effect of tectorigenin on MCP-1 and ICAM-1 mRNA expression in injured vascular endothelial cells]. Zhongguo Zhong Yao Za Zhi.35(15):2001-3.

[139] Lee BS, Shim SM, Heo J, Pae HO, Seo BY, Han SY, et al. Wogonin suppresses TARC expression induced by mite antigen via heme oxygenase 1 in human keratinocytes. Suppressive effect of wogonin on mite antigen-induced TARC expression. J Dermatol Sci. 2007;46(1):31-40.

[140] Hong JY, Lee KE, Kim KW, Sohn MH, Kim KE. Chitinase induce the release of IL-8 in human airway epithelial cells, via Ca2+-dependent PKC and ERK pathways. Scand J Immunol.72(1):15-21.

[141] Liao YR, Hsu JY, Chu JJ, Fu LS. Caffeic acid phenethyl ester suppresses the induction of eotaxin in human lung fibroblast cells. J Asthma.47(3):233-7.

[142] Han KH, Hong KH, Ko J, Rhee KS, Hong MK, Kim JJ, et al. Lysophosphatidylcholine up-regulates CXCR4 chemokine receptor expression in human CD4 T cells. J Leukoc Biol. 2004;76(1):195-202.

[143] Lin YT, Hsu JY, Chen CJ, Chu JJ, Fu LS. Caffeic acid phenethyl ester suppresses eotaxin secretion and nuclear p-STAT6 in human lung fibroblast cells. J Microbiol Immunol Infect.

[144] Qin S, Alcorn JF, Craigo JK, Tjoeng C, Tarwater PM, Kolls JK, et al. Epigallocatechin-3-gallate reduces airway inflammation in mice through binding to proinflammatory chemokines and inhibiting inflammatory cell recruitment. J Immunol.186(6): 3693-700.

[145] Melgarejo E, Medina MA, Sanchez-Jimenez F, Urdiales JL. Epigallocatechin gallate reduces human monocyte mobility and adhesion in vitro. $\mathrm{Br} \mathrm{J}$ Pharmacol. 2009;158(7):1705-12.

[146] Melgarejo E, Medina MA, Sanchez-Jimenez F, Botana LM, Dominguez M, Escribano $\mathrm{L}$, et al. (-)-Epigallocatechin-3-gallate interferes with mast cell adhesiveness, migration and its potential to recruit monocytes. Cell Mol Life Sci. 2007;64(19-20):2690-701.

[147] Takano K, Nakaima K, Nitta M, Shibata F, Nakagawa H. Inhibitory effect of (-)-epigallocatechin 3-gallate, a polyphenol of green tea, on neutrophil chemotaxis in vitro and in vivo. J Agric Food Chem. 2004;52(14):4571-6.

[148] Kiss AK, Filipek A, Czerwinska M, Naruszewicz M. Oenothera paradoxa defatted seeds extract and its bioactive component penta-O-galloyl-beta-D-glucose decreased production of reactive oxygen species and inhibited release of leukotriene B4, interleukin-8, elastase, and myeloperoxidase in human neutrophils. J Agric Food Chem. 58(18):9960-6. 
[149] Ju SM, Song HY, Lee SJ, Seo WY, Sin DH, Goh AR, et al. Suppression of thymus- and activation-regulated chemokine (TARC/CCL17) production by 1,2,3,4,6-penta-O-galloyl-beta-D-glucose via blockade of NF-kappaB and STAT1 activation in the HaCaT cells. Biochem Biophys Res Commun. 2009;387(1):115-20.

[150] Cavalher-Machado SC, Rosas EC, Brito Fde A, Heringe AP, de Oliveira RR, Kaplan MA, et al. The anti-allergic activity of the acetate fraction of Schinus terebinthifolius leaves in IgE induced mice paw edema and pleurisy. Int Immunopharmacol. 2008;8(11):1552-60.

[151] Kim HK, Lee JJ, Lee JS, Park YM, Yoon TR. Rosmarinic acid down-regulates the LPSinduced production of monocyte chemoattractant protein-1 (MCP-1) and macrophage inflammatory protein-1alpha (MIP-1alpha) via the MAPK pathway in bonemarrow derived dendritic cells. Mol Cells. 2008;26(6):583-9.

[152] Sakai S, Sugawara T, Matsubara K, Hirata T. Inhibitory effect of carotenoids on the degranulation of mast cells via suppression of antigen-induced aggregation of high affinity IgE receptors. J Biol Chem. 2009;284(41):28172-9.

[153] Cheong H, Ryu SY, Oak MH, Cheon SH, Yoo GS, Kim KM. Studies of structure activity relationship of flavonoids for the anti-allergic actions. Arch Pharm Res. 1998;21(4):478-80.

[154] Son JK, Son MJ, Lee E, Moon TC, Son KH, Kim CH, et al. Ginkgetin, a Biflavone from Ginko biloba leaves, inhibits cyclooxygenases-2 and 5-lipoxygenase in mouse bone marrow-derived mast cells. Biol Pharm Bull. 2005;28(12):2181-4.

[155] Xu F, Matsuda H, Hata H, Sugawara K, Nakamura S, Yoshikawa M. Structures of new flavonoids and benzofuran-type stilbene and degranulation inhibitors of rat basophilic leukemia cells from the Brazilian herbal medicine Cissus sicyoides. Chem Pharm Bull (Tokyo). 2009;57(10):1089-95.

[156] Park SH, Park EK, Kim DH. Passive cutaneous anaphylaxis-inhibitory activity of flavanones from Citrus unshiu and Poncirus trifoliata. Planta Med. 2005;71(1):24-7.

[157] Cheong H, Ryu SY, Kim KM. Anti-allergic action of resveratrol and related hydroxystilbenes. Planta Med. 1999;65(3):266-8.

[158] Quan W, Lee HJ, Kim CY, Noh CW, Um BH, Oak MH, et al. Anti-allergic prenylated flavonoids from the roots of Sophora flavescens. Planta Med. 2008;74(2):168-70.

[159] Park EK, Shin YW, Lee HU, Lee CS, Kim DH. Passive cutaneous anaphylaxis-inhibitory action of tectorigenin, a metabolite of tectoridin by intestinal microflora. Biol Pharm Bull. 2004;27(7):1099-102.

[160] Ito H, Miyazaki T, Ono M, Sakurai H. Antiallergic activities of rabdosiin and its related compounds: chemical and biochemical evaluations. Bioorg Med Chem. 1998;6(7): 1051-6. 
[161] Matsuda H, Tewtrakul S, Morikawa T, Nakamura A, Yoshikawa M. Anti-allergic principles from Thai zedoary: structural requirements of curcuminoids for inhibition of degranulation and effect on the release of TNF-alpha and IL-4 in RBL-2H3 cells. Bioorg Med Chem. 2004;12(22):5891-8.

[162] Nishikawa H, Wakano K, Kitani S. Inhibition of NADPH oxidase subunits translocation by tea catechin EGCG in mast cell. Biochem Biophys Res Commun. 2007;362(2): 504-9.

[163] Kim Y, Kim K, Lee H, Han S, Lee YS, Choe J, et al. Celastrol binds to ERK and inhibits FcepsilonRI signaling to exert an anti-allergic effect. Eur J Pharmacol. 2009;612(1-3):131-42.

[164] Kim TJ, Nam KW, Kim B, Lee SJ, Oh KB, Kim KH, et al. Inhibitory Effects of Costunolide Isolated from Laurus nobilis on IgE-induced Degranulation of Mast Cell-like RBL-2H3 Cells and the Growth of Y16 pro-B Cells. Phytother Res.

[165] Duan W, Chan JH, McKay K, Crosby JR, Choo HH, Leung BP, et al. Inhaled p38alpha mitogen-activated protein kinase antisense oligonucleotide attenuates asthma in mice. Am J Respir Crit Care Med. 2005;171(6):571-8. Epub 2004/11/24.

[166] Hirota R, Roger NN, Nakamura H, Song HS, Sawamura M, Suganuma N. Anti-inflammatory effects of limonene from yuzu (Citrus junos Tanaka) essential oil on eosinophils. J Food Sci.75(3):H87-92.

[167] Kannaiyan R, Shanmugam MK, Sethi G. Molecular targets of celastrol derived from Thunder of God Vine: potential role in the treatment of inflammatory disorders and cancer. Cancer Lett.303(1):9-20.

[168] Kim DY, Park JW, Jeoung D, Ro JY. Celastrol suppresses allergen-induced airway inflammation in a mouse allergic asthma model. Eur J Pharmacol. 2009;612(1-3):98-105. Epub 2009/04/10.

[169] Adcock IM, Caramori G, Chung KF. New targets for drug development in asthma. Lancet. 2008;372(9643):1073-87. Epub 2008/09/23.

[170] Kim JY, Kwon EY, Lee YS, Kim WB, Ro JY. Eupatilin blocks mediator release via tyrosine kinase inhibition in activated guinea pig lung mast cells. Journal of toxicology and environmental health Part A. 2005;68(23-24):2063-80. Epub 2005/12/06.

[171] Kampe M, Lampinen M, Stolt I, Janson C, Stalenheim G, Carlson M. PI3-kinase regulates eosinophil and neutrophil degranulation in patients with allergic rhinitis and allergic asthma irrespective of allergen challenge model. Inflammation.35(1):230-9.

[172] Yu T, Lee YJ, Jang HJ, Kim AR, Hong S, Kim TW, et al. Anti-inflammatory activity of Sorbus commixta water extract and its molecular inhibitory mechanism. J Ethnopharmacol.134(2):493-500.

[173] Wen D, Nong Y, Morgan JG, Gangurde P, Bielecki A, Dasilva J, et al. A selective small molecule IkappaB Kinase beta inhibitor blocks nuclear factor kappaB-mediated 
inflammatory responses in human fibroblast-like synoviocytes, chondrocytes, and mast cells. J Pharmacol Exp Ther. 2006;317(3):989-1001. Epub 2006/03/10.

[174] Ziegelbauer K, Gantner F, Lukacs NW, Berlin A, Fuchikami K, Niki T, et al. A selective novel low-molecular-weight inhibitor of IkappaB kinase-beta (IKK-beta) prevents pulmonary inflammation and shows broad anti-inflammatory activity. Br J Pharmacol. 2005;145(2):178-92. Epub 2005/03/09.

[175] Li J, Luo L, Wang X, Liao B, Li G. Inhibition of NF-kappaB expression and allergeninduced airway inflammation in a mouse allergic asthma model by andrographolide. Cell Mol Immunol. 2009;6(5):381-5.

[176] Zhang DH, Cohn L, Ray P, Bottomly K, Ray A. Transcription factor GATA-3 is differentially expressed in murine Th1 and Th2 cells and controls Th2-specific expression of the interleukin-5 gene. J Biol Chem. 1997;272(34):21597-603. Epub 1997/08/22.

[177] Nakamura Y, Ghaffar O, Olivenstein R, Taha RA, Soussi-Gounni A, Zhang DH, et al. Gene expression of the GATA-3 transcription factor is increased in atopic asthma. J Allergy Clin Immunol. 1999;103(2 Pt 1):215-22. Epub 1999/02/09.

[178] Popescu FD, Popescu F. A review of antisense therapeutic interventions for molecular biological targets in asthma. Biologics : targets \& therapy. 2007;1(3):271-83. Epub 2007/09/01.

[179] Park HJ, Lee CM, Jung ID, Lee JS, Jeong YI, Chang JH, et al. Quercetin regulates Th1/Th2 balance in a murine model of asthma. Int Immunopharmacol. 2009;9(3): 261-7.

[180] Macian F, Lopez-Rodriguez C, Rao A. Partners in transcription: NFAT and AP-1. Oncogene. 2001;20(19):2476-89. Epub 2001/06/13.

[181] Martinez-Martinez S, Redondo JM. Inhibitors of the calcineurin/NFAT pathway. Current medicinal chemistry. 2004;11(8):997-1007. Epub 2004/04/14.

[182] Roehrl MH, Kang S, Aramburu J, Wagner G, Rao A, Hogan PG. Selective inhibition of calcineurin-NFAT signaling by blocking protein-protein interaction with small organic molecules. Proceedings of the National Academy of Sciences of the United States of America. 2004;101(20):7554-9. Epub 2004/05/08.

[183] Honda K, Marquillies P, Capron M, Dombrowicz D. Peroxisome proliferator-activated receptor gamma is expressed in airways and inhibits features of airway remodeling in a mouse asthma model. J Allergy Clin Immunol. 2004;113(5):882-8. Epub 2004/05/08.

[184] Belvisi MG, Mitchell JA. Targeting PPAR receptors in the airway for the treatment of inflammatory lung disease. Br J Pharmacol. 2009;158(4):994-1003. Epub 2009/08/26.

[185] Zhou L, Tang YP, Gao L, Fan XS, Liu CM, Wu DK. Separation, characterization and dose-effect relationship of the PPARgamma-activating bio-active constituents in the 
Chinese herb formulation 'San-Ao decoction'. Molecules. 2009;14(10):3942-51. Epub $2009 / 11 / 20$.

[186] Culpitt SV, Rogers DF, Fenwick PS, Shah P, De Matos C, Russell RE, et al. Inhibition by red wine extract, resveratrol, of cytokine release by alveolar macrophages in COPD. Thorax. 2003;58(11):942-6. Epub 2003/10/31.

[187] Lee NH, Lee MY, Lee JA, Jung DY, Seo CS, Kim JH, et al. Anti-asthmatic effect of Sanguisorba officinalis L. and potential role of heme oxygenase- 1 in an ovalbumininduced murine asthma model. Int J Mol Med. 2010;26(2):201-8. Epub 2010/07/03.

[188] Choi JH, Hwang YP, Lee HS, Jeong HG. Inhibitory effect of Platycodi Radix on ovalbumin-induced airway inflammation in a murine model of asthma. Food Chem Toxicol. 2009;47(6):1272-9. Epub 2009/03/07.

[189] Lee MY, Seo CS, Ha H, Jung D, Lee H, Lee NH, et al. Protective effects of Ulmus davidiana var. japonica against OVA-induced murine asthma model via upregulation of heme oxygenase-1. J Ethnopharmacol. 2010;130(1):61-9. Epub 2010/04/28.

[190] Lee MY, Lee NH, Seo CS, Lee JA, Jung D, Kim JH, et al. Alpinia katsumadai seed extract attenuate oxidative stress and asthmatic activity in a mouse model of allergic asthma. Food Chem Toxicol. 2010;48(6):1746-52. Epub 2010/04/14.

[191] Lee JH, Zhou HY, Cho SY, Kim YS, Lee YS, Jeong CS. Anti-inflammatory mechanisms of apigenin: inhibition of cyclooxygenase-2 expression, adhesion of monocytes to human umbilical vein endothelial cells, and expression of cellular adhesion molecules. Arch Pharm Res. 2007;30(10):1318-27.

[192] Lin HY, Juan SH, Shen SC, Hsu FL, Chen YC. Inhibition of lipopolysaccharide-induced nitric oxide production by flavonoids in RAW264.7 macrophages involves heme oxygenase-1. Biochem Pharmacol. 2003;66(9):1821-32.

[193] Qiao S, Li W, Tsubouchi R, Haneda M, Murakami K, Takeuchi F, et al. Rosmarinic acid inhibits the formation of reactive oxygen and nitrogen species in RAW264.7 macrophages. Free Radic Res. 2005;39(9):995-1003.

[194] Schubert R, Kitz R, Beermann C, Rose MA, Lieb A, Sommerer PC, et al. Effect of n-3 polyunsaturated fatty acids in asthma after low-dose allergen challenge. Int Arch Allergy Immunol. 2009;148(4):321-9.

[195] Riedl MA, Nel AE. Importance of oxidative stress in the pathogenesis and treatment of asthma. Current opinion in allergy and clinical immunology. 2008;8(1):49-56. Epub 2008/01/12.

[196] Allen S, Britton JR, Leonardi-Bee JA. Association between antioxidant vitamins and asthma outcome measures: systematic review and meta-analysis. Thorax. 2009;64(7): 610-9. 
[197] Al Senaidy AM. Serum vitamin A and beta-carotene levels in children with asthma. J Asthma. 2009;46(7):699-702.

[198] Hazlewood LC, Wood LG, Hansbro PM, Foster PS. Dietary lycopene supplementation suppresses Th2 responses and lung eosinophilia in a mouse model of allergic asthma. J Nutr Biochem.22(1):95-100.

[199] Fang H, Jin H, Wang H. Effect of all-trans retinoic acid on airway inflammation in asthmatic rats and its mechanism. J Huazhong Univ Sci Technolog Med Sci. 2004;24(3):229-32.

[200] Tsai YC, Chang HW, Chang TT, Lee MS, Chu YT, Hung CH. Effects of all-trans retinoic acid on Th1- and Th2-related chemokines production in monocytes. Inflammation. 2008;31(6):428-33.

[201] Day RM, Lee YH, Park AM, Suzuki YJ. Retinoic acid inhibits airway smooth muscle cell migration. Am J Respir Cell Mol Biol. 2006;34(6):695-703.

[202] Schuster GU, Kenyon NJ, Stephensen CB. Vitamin A deficiency decreases and high dietary vitamin A increases disease severity in the mouse model of asthma. J Immunol. 2008;180(3):1834-42.

[203] McGowan SE, Smith J, Holmes AJ, Smith LA, Businga TR, Madsen MT, et al. Vitamin A deficiency promotes bronchial hyperreactivity in rats by altering muscarinic $\mathrm{M}(2)$ receptor function. Am J Physiol Lung Cell Mol Physiol. 2002;282(5):L1031-9.

[204] Al-Abdulla NO, Al Naama LM, Hassan MK. Antioxidant status in acute asthmatic attack in children. J Pak Med Assoc.60(12):1023-7.

[205] Kongerud J, Crissman K, Hatch G, Alexis N. Ascorbic acid is decreased in induced sputum of mild asthmatics. Inhal Toxicol. 2003;15(2):101-9.

[206] Miyake Y, Sasaki S, Tanaka K, Hirota Y. Consumption of vegetables, fruit, and antioxidants during pregnancy and wheeze and eczema in infants. Allergy.65(6):758-65.

[207] Jeong YJ, Kim JH, Kang JS, Lee WJ, Hwang YI. Mega-dose vitamin C attenuated lung inflammation in mouse asthma model. Anat Cell Biol.43(4):294-302.

[208] Chang HH, Chen CS, Lin JY. High dose vitamin C supplementation increases the Th1/Th2 cytokine secretion ratio, but decreases eosinophilic infiltration in bronchoalveolar lavage fluid of ovalbumin-sensitized and challenged mice. J Agric Food Chem. 2009;57(21):10471-6.

[209] Tecklenburg SL, Mickleborough TD, Fly AD, Bai Y, Stager JM. Ascorbic acid supplementation attenuates exercise-induced bronchoconstriction in patients with asthma. Respir Med. 2007;101(8):1770-8.

[210] Fogarty A, Lewis SA, Scrivener SL, Antoniak M, Pacey S, Pringle M, et al. Oral magnesium and vitamin $C$ supplements in asthma: a parallel group randomized placebocontrolled trial. Clin Exp Allergy. 2003;33(10):1355-9. 
[211] Kaur B, Rowe BH, Arnold E. Vitamin C supplementation for asthma. Cochrane Database Syst Rev. 2009(1):CD000993.

[212] Guaiquil VH, Vera JC, Golde DW. Mechanism of vitamin C inhibition of cell death induced by oxidative stress in glutathione-depleted HL-60 cells. J Biol Chem. 2001;276(44):40955-61. Epub 2001/09/05.

[213] Benkoussa M, Brand C, Delmotte MH, Formstecher P, Lefebvre P. Retinoic acid receptors inhibit AP1 activation by regulating extracellular signal-regulated kinase and CBP recruitment to an AP1-responsive promoter. Molecular and cellular biology. 2002;22(13):4522-34. Epub 2002/06/08.

[214] Meves A, Stock SN, Beyerle A, Pittelkow MR, Peus D. Vitamin C derivative ascorbyl palmitate promotes ultraviolet-B-induced lipid peroxidation and cytotoxicity in keratinocytes. The Journal of investigative dermatology. 2002;119(5):1103-8. Epub $2002 / 11 / 26$

[215] Bakkeheim E, Mowinckel P, Carlsen KH, Burney P, Carlsen KC. Altered oxidative state in schoolchildren with asthma and allergic rhinitis. Pediatr Allergy Immunol. 22(2):178-85.

[216] Turner SW, Campbell D, Smith N, Craig LC, McNeill G, Forbes SH, et al. Associations between fetal size, maternal \{alpha\}-tocopherol and childhood asthma. Thorax. 65(5):391-7.

[217] de Luis DA, Armentia A, Aller R, Asensio A, Sedano E, Izaola O, et al. Dietary intake in patients with asthma: a case control study. Nutrition. 2005;21(3):320-4.

[218] Misso NL, Brooks-Wildhaber J, Ray S, Vally H, Thompson PJ. Plasma concentrations of dietary and nondietary antioxidants are low in severe asthma. Eur Respir J. 2005;26(2):257-64.

[219] Pearson PJ, Lewis SA, Britton J, Fogarty A. Vitamin E supplements in asthma: a parallel group randomised placebo controlled trial. Thorax. 2004;59(8):652-6.

[220] Mabalirajan U, Aich J, Leishangthem GD, Sharma SK, Dinda AK, Ghosh B. Effects of vitamin $\mathrm{E}$ on mitochondrial dysfunction and asthma features in an experimental allergic murine model. J Appl Physiol. 2009;107(4):1285-92.

[221] Lim Y, Vasu VT, Valacchi G, Leonard S, Aung HH, Schock BC, et al. Severe vitamin E deficiency modulates airway allergic inflammatory responses in the murine asthma model. Free Radic Res. 2008;42(4):387-96.

[222] Chhabra SK, Yasir A, Chaudhry K, Shah B. Effect of ozone on response to ovalbumin \& its modulation by vitamins C \& E in sensitized guinea pigs. Indian J Med Res. 132:87-93. 
[223] Suchankova J, Voprsalova M, Kottova M, Semecky V, Visnovsky P. Effects of oral alpha-tocopherol on lung response in rat model of allergic asthma. Respirology. 2006;11(4):414-21.

[224] Grabarczyk M, Podstawka U, Kopec-Szlezak J. [Protection of human peripheral blood leukocytes with vitamin E and C from toxic effects of fenarimol in vitro]. Acta haematologica Polonica. 1991;22(1):136-44. Epub 1991/01/01. Oslanianie leukocytow ludzkiej krwi obwodowej za pomoca witamin E i C przed skutkami toksycznego dzialania fenarimolu in vitro.

[225] Wiser J, Alexis NE, Jiang Q, Wu W, Robinette C, Roubey R, et al. In vivo gamma-tocopherol supplementation decreases systemic oxidative stress and cytokine responses of human monocytes in normal and asthmatic subjects. Free radical biology \& medicine. 2008;45(1):40-9. Epub 2008/04/15.

[226] Berdnikovs S, Abdala-Valencia H, McCary C, Somand M, Cole R, Garcia A, et al. Isoforms of vitamin $\mathrm{E}$ have opposing immunoregulatory functions during inflammation by regulating leukocyte recruitment. J Immunol. 2009;182(7):4395-405. Epub 2009/03/21.

[227] Brehm JM, Schuemann B, Fuhlbrigge AL, Hollis BW, Strunk RC, Zeiger RS, et al. Serum vitamin $\mathrm{D}$ levels and severe asthma exacerbations in the Childhood Asthma Management Program study. J Allergy Clin Immunol.126(1):52-8 e5.

[228] Chinellato I, Piazza M, Sandri M, Peroni D, Piacentini G, Boner AL. Vitamin D serum levels and markers of asthma control in Italian children. J Pediatr.158(3):437-41.

[229] Sutherland ER, Goleva E, Jackson LP, Stevens AD, Leung DY. Vitamin D levels, lung function, and steroid response in adult asthma. Am J Respir Crit Care Med.181(7): 699-704.

[230] Majak P, Olszowiec-Chlebna M, Smejda K, Stelmach I. Vitamin D supplementation in children may prevent asthma exacerbation triggered by acute respiratory infection. J Allergy Clin Immunol.127(5):1294-6.

[231] Penna G, Adorini L. 1 Alpha,25-dihydroxyvitamin D3 inhibits differentiation, maturation, activation, and survival of dendritic cells leading to impaired alloreactive $\mathrm{T}$ cell activation. J Immunol. 2000;164(5):2405-11. Epub 2000/02/29.

[232] Chambers ES, Hawrylowicz CM. The impact of vitamin D on regulatory T cells. Curr Allergy Asthma Rep.11(1):29-36.

[233] Xystrakis E, Kusumakar S, Boswell S, Peek E, Urry Z, Richards DF, et al. Reversing the defective induction of IL-10-secreting regulatory T cells in glucocorticoid-resistant asthma patients. The Journal of clinical investigation. 2006;116(1):146-55. Epub 2005/12/13.

[234] Damera G, Fogle HW, Lim P, Goncharova EA, Zhao H, Banerjee A, et al. Vitamin D inhibits growth of human airway smooth muscle cells through growth factor-in- 
duced phosphorylation of retinoblastoma protein and checkpoint kinase 1. Br J Pharmacol. 2009;158(6):1429-41. Epub 2009/10/10.

[235] Knekt P, Kumpulainen J, Jarvinen R, Rissanen H, Heliovaara M, Reunanen A, et al. Flavonoid intake and risk of chronic diseases. The American journal of clinical nutrition. 2002;76(3):560-8. Epub 2002/08/29.

[236] Aggarwal BB, Shishodia S. Molecular targets of dietary agents for prevention and therapy of cancer. Biochem Pharmacol. 2006;71(10):1397-421. Epub 2006/03/28.

[237] Rogerio AP, Dora CL, Andrade EL, Chaves JS, Silva LF, Lemos-Senna E, et al. Antiinflammatory effect of quercetin-loaded microemulsion in the airways allergic inflammatory model in mice. Pharmacol Res.61(4):288-97.

[238] Xie YC, Dong XW, Wu XM, Yan XF, Xie QM. Inhibitory effects of flavonoids extracted from licorice on lipopolysaccharide-induced acute pulmonary inflammation in mice. Int Immunopharmacol. 2009;9(2):194-200.

[239] Jung WK, Choi I, Oh S, Park SG, Seo SK, Lee SW, et al. Anti-asthmatic effect of marine red alga (Laurencia undulata) polyphenolic extracts in a murine model of asthma. Food Chem Toxicol. 2009;47(2):293-7.

[240] Watson RR, Zibadi S, Rafatpanah H, Jabbari F, Ghasemi R, Ghafari J, et al. Oral administration of the purple passion fruit peel extract reduces wheeze and cough and improves shortness of breath in adults with asthma. Nutr Res. 2008;28(3):166-71.

[241] Candelario-Jalil E, de Oliveira AC, Graf S, Bhatia HS, Hull M, Munoz E, et al. Resveratrol potently reduces prostaglandin E2 production and free radical formation in lipopolysaccharide-activated primary rat microglia. Journal of neuroinflammation. 2007;4:25. Epub 2007/10/12.

[242] Lagouge M, Argmann C, Gerhart-Hines Z, Meziane H, Lerin C, Daussin F, et al. Resveratrol improves mitochondrial function and protects against metabolic disease by activating SIRT1 and PGC-1alpha. Cell. 2006;127(6):1109-22. Epub 2006/11/23.

[243] Zbikowska HM, Wachowicz B, Krajewski T. Selenium compounds inhibit the biological activity of blood platelets. Platelets. 1999;10(2-3):185-90. Epub 2006/06/28.

[244] Horvathova M, Jahnova E, Gazdik F. Effect of selenium supplementation in asthmatic subjects on the expression of endothelial cell adhesion molecules in culture. Biological trace element research. 1999;69(1):15-26. Epub 1999/06/26.

[245] Guo CH, Liu PJ, Hsia S, Chuang CJ, Chen PC. Role of certain trace minerals in oxidative stress, inflammation, CD4/CD8 lymphocyte ratios and lung function in asthmatic patients. Ann Clin Biochem.48(Pt 4):344-51.

[246] Hassan AM. Selenium status in patients with aspirin-induced asthma. Ann Clin Biochem. 2008;45(Pt 5):508-12. 
[247] Urushidate S, Matsuzaka M, Okubo N, Iwasaki H, Hasebe T, Tsuya R, et al. Association between concentration of trace elements in serum and bronchial asthma among Japanese general population. J Trace Elem Med Biol.24(4):236-42.

[248] Burney P, Potts J, Makowska J, Kowalski M, Phillips J, Gnatiuc L, et al. A case-control study of the relation between plasma selenium and asthma in European populations: a GAL2EN project. Allergy. 2008;63(7):865-71.

[249] Hoffmann PR, Jourdan-Le Saux C, Hoffmann FW, Chang PS, Bollt O, He Q, et al. A role for dietary selenium and selenoproteins in allergic airway inflammation. J Immunol. 2007;179(5):3258-67.

[250] Shaheen SO, Newson RB, Rayman MP, Wong AP, Tumilty MK, Phillips JM, et al. Randomised, double blind, placebo-controlled trial of selenium supplementation in adult asthma. Thorax. 2007;62(6):483-90.

[251] Nie L, Wise ML, Peterson DM, Meydani M. Avenanthramide, a polyphenol from oats, inhibits vascular smooth muscle cell proliferation and enhances nitric oxide production. Atherosclerosis. 2006;186(2):260-6. Epub 2005/09/06.

[252] Guo W, Wise ML, Collins FW, Meydani M. Avenanthramides, polyphenols from oats, inhibit IL-1beta-induced NF-kappaB activation in endothelial cells. Free radical biology \& medicine. 2008;44(3):415-29. Epub 2007/12/08.

[253] Sur R, Nigam A, Grote D, Liebel F, Southall MD. Avenanthramides, polyphenols from oats, exhibit anti-inflammatory and anti-itch activity. Arch Dermatol Res. 2008;300(10):569-74. Epub 2008/05/08.

[254] Ammon HP. Modulation of the immune system by Boswellia serrata extracts and boswellic acids. Phytomedicine.17(11):862-7.

[255] Khajuria A, Gupta A, Suden P, Singh S, Malik F, Singh J, et al. Immunomodulatory activity of biopolymeric fraction BOS 2000 from Boswellia serrata. Phytother Res. 2008;22(3):340-8.

[256] Gayathri B, Manjula N, Vinaykumar KS, Lakshmi BS, Balakrishnan A. Pure compound from Boswellia serrata extract exhibits anti-inflammatory property in human PBMCs and mouse macrophages through inhibition of TNFalpha, IL-1beta, NO and MAP kinases. Int Immunopharmacol. 2007;7(4):473-82.

[257] Pungle P, Banavalikar M, Suthar A, Biyani M, Mengi S. Immunomodulatory activity of boswellic acids of Boswellia serrata Roxb. Indian J Exp Biol. 2003;41(12):1460-2.

[258] Siemoneit U, Hofmann B, Kather N, Lamkemeyer T, Madlung J, Franke L, et al. Identification and functional analysis of cyclooxygenase-1 as a molecular target of boswellic acids. Biochem Pharmacol. 2008;75(2):503-13. 
[259] Ammon HP, Mack T, Singh GB, Safayhi H. Inhibition of leukotriene B4 formation in rat peritoneal neutrophils by an ethanolic extract of the gum resin exudate of Boswellia serrata. Planta Med. 1991;57(3):203-7.

[260] Gupta I, Gupta V, Parihar A, Gupta S, Ludtke R, Safayhi H, et al. Effects of Boswellia serrata gum resin in patients with bronchial asthma: results of a double-blind, placebo-controlled, 6-week clinical study. Eur J Med Res. 1998;3(11):511-4.

[261] Mynott TL, Ladhams A, Scarmato P, Engwerda CR. Bromelain, from pineapple stems, proteolytically blocks activation of extracellular regulated kinase-2 in T cells. J Immunol. 1999;163(5):2568-75.

[262] Engwerda CR, Andrew D, Ladhams A, Mynott TL. Bromelain modulates T cell and B cell immune responses in vitro and in vivo. Cell Immunol. 2001;210(1):66-75.

[263] Hale LP, Greer PK, Sempowski GD. Bromelain treatment alters leukocyte expression of cell surface molecules involved in cellular adhesion and activation. Clin Immunol. 2002;104(2):183-90.

[264] Secor ER, Jr., Singh A, Guernsey LA, McNamara JT, Zhan L, Maulik N, et al. Bromelain treatment reduces CD25 expression on activated CD4+ T cells in vitro. Int Immunopharmacol. 2009;9(3):340-6.

[265] Manhart N, Akomeah R, Bergmeister H, Spittler A, Ploner M, Roth E. Administration of proteolytic enzymes bromelain and trypsin diminish the number of CD4+ cells and the interferon-gamma response in Peyer's patches and spleen in endotoxemic balb/c mice. Cell Immunol. 2002;215(2):113-9.

[266] Secor ER, Jr., Carson WFt, Cloutier MM, Guernsey LA, Schramm CM, Wu CA, et al. Bromelain exerts anti-inflammatory effects in an ovalbumin-induced murine model of allergic airway disease. Cell Immunol. 2005;237(1):68-75.

[267] Secor ER, Carson WF, Singh A, Pensa M, Guernsey LA, Schramm CM, et al. Oral Bromelain Attenuates Inflammation in an Ovalbumin-induced Murine Model of Asthma. Evid Based Complement Alternat Med. 2008;5(1):61-9.

[268] Szelenyi I, Brune K. Herbal remedies for asthma treatment: between myth and reality. Drugs Today (Barc). 2002;38(4):265-303.

[269] Shimoda H, Tanaka J, Yamada E, Morikawa T, Kasajima N, Yoshikawa M. Anti type I allergic property of Japanese butterbur extract and its mast cell degranulation inhibitory ingredients. J Agric Food Chem. 2006;54(8):2915-20.

[270] Thomet OA, Wiesmann UN, Blaser K, Simon HU. Differential inhibition of inflammatory effector functions by petasin, isopetasin and neopetasin in human eosinophils. Clin Exp Allergy. 2001;31(8):1310-20. 
[271] Bickel D, Roder T, Bestmann HJ, Brune K. Identification and characterization of inhibitors of peptido-leukotriene-synthesis from Petasites hybridus. Planta Med. 1994;60(4):318-22.

[272] Ko WC, Lei CB, Lin YL, Chen CF. Relaxant effects of petasins in isolated guinea pig trachea and their structure-activity relationships. Planta Med. 2000;66(7):650-2.

[273] Ziolo G, Samochowiec L. Study on clinical properties and mechanisms of action of Petasites in bronchial asthma and chronic obstructive bronchitis. Pharm Acta Helv. 1998;72(6):378-80.

[274] Lee DK, Haggart K, Robb FM, Lipworth BJ. Butterbur, a herbal remedy, confers complementary anti-inflammatory activity in asthmatic patients receiving inhaled corticosteroids. Clin Exp Allergy. 2004;34(1):110-4.

[275] Esatbeyoglu T, Huebbe P, Ernst IM, Chin D, Wagner AE, Rimbach G. Curcumin-from molecule to biological function. Angew Chem Int Ed Engl.51(22):5308-32.

[276] Aggarwal BB, Harikumar KB. Potential therapeutic effects of curcumin, the anti-inflammatory agent, against neurodegenerative, cardiovascular, pulmonary, metabolic, autoimmune and neoplastic diseases. Int J Biochem Cell Biol. 2009;41(1):40-59.

[277] Reddy AC, Lokesh BR. Studies on spice principles as antioxidants in the inhibition of lipid peroxidation of rat liver microsomes. Mol Cell Biochem. 1992;111(1-2):117-24.

[278] Dikshit M, Rastogi L, Shukla R, Srimal RC. Prevention of ischaemia-induced biochemical changes by curcumin \& quinidine in the cat heart. Indian J Med Res. 1995;101:31-5.

[279] Motterlini R, Foresti R, Bassi R, Green CJ. Curcumin, an antioxidant and anti-inflammatory agent, induces heme oxygenase- 1 and protects endothelial cells against oxidative stress. Free Radic Biol Med. 2000;28(8):1303-12.

[280] Brouet I, Ohshima H. Curcumin, an anti-tumour promoter and anti-inflammatory agent, inhibits induction of nitric oxide synthase in activated macrophages. Biochem Biophys Res Commun. 1995;206(2):533-40.

[281] Pan MH, Lin-Shiau SY, Ho CT, Lin JH, Lin JK. Suppression of lipopolysaccharide-induced nuclear factor-kappaB activity by theaflavin-3,3'-digallate from black tea and other polyphenols through down-regulation of IkappaB kinase activity in macrophages. Biochem Pharmacol. 2000;59(4):357-67.

[282] Onoda M, Inano $\mathrm{H}$. Effect of curcumin on the production of nitric oxide by cultured rat mammary gland. Nitric Oxide. 2000;4(5):505-15.

[283] Literat A, Su F, Norwicki M, Durand M, Ramanathan R, Jones CA, et al. Regulation of pro-inflammatory cytokine expression by curcumin in hyaline membrane disease (HMD). Life Sci. 2001;70(3):253-67. 
[284] Biswas S, Rahman I. Modulation of steroid activity in chronic inflammation: a novel anti-inflammatory role for curcumin. Mol Nutr Food Res. 2008;52(9):987-94.

[285] Kurup VP, Barrios CS, Raju R, Johnson BD, Levy MB, Fink JN. Immune response modulation by curcumin in a latex allergy model. Clin Mol Allergy. 2007;5:1.

[286] Ram A, Das M, Ghosh B. Curcumin attenuates allergen-induced airway hyperresponsiveness in sensitized guinea pigs. Biol Pharm Bull. 2003;26(7):1021-4.

[287] Lee JH, Kim JW, Ko NY, Mun SH, Her E, Kim BK, et al. Curcumin, a constituent of curry, suppresses IgE-mediated allergic response and mast cell activation at the level of Syk. J Allergy Clin Immunol. 2008;121(5):1225-31.

[288] Sato H, Goto W, Yamamura J, Kurokawa M, Kageyama S, Takahara T, et al. Therapeutic basis of glycyrrhizin on chronic hepatitis B. Antiviral Res. 1996;30(2-3):171-7.

[289] van Rossum TG, Vulto AG, de Man RA, Brouwer JT, Schalm SW. Review article: glycyrrhizin as a potential treatment for chronic hepatitis C. Aliment Pharmacol Ther. 1998;12(3):199-205.

[290] Sekizawa T, Yanagi K, Itoyama Y. Glycyrrhizin increases survival of mice with herpes simplex encephalitis. Acta Virol. 2001;45(1):51-4.

[291] Park HY, Park SH, Yoon HK, Han MJ, Kim DH. Anti-allergic activity of 18beta-glycyrrhetinic acid-3-O-beta-D-glucuronide. Arch Pharm Res. 2004;27(1):57-60.

[292] Ram A, Mabalirajan U, Das M, Bhattacharya I, Dinda AK, Gangal SV, et al. Glycyrrhizin alleviates experimental allergic asthma in mice. Int Immunopharmacol. 2006;6(9):1468-77.

[293] Shin YW, Bae EA, Lee B, Lee SH, Kim JA, Kim YS, et al. In vitro and in vivo antiallergic effects of Glycyrrhiza glabra and its components. Planta Med. 2007;73(3):257-61.

[294] Asl MN, Hosseinzadeh H. Review of pharmacological effects of Glycyrrhiza sp. and its bioactive compounds. Phytother Res. 2008;22(6):709-24.

[295] Hsu CH, Lu CM, Chang TT. Efficacy and safety of modified Mai-Men-Dong-Tang for treatment of allergic asthma. Pediatr Allergy Immunol. 2005;16(1):76-81.

[296] Chan CK, Kuo ML, Shen JJ, See LC, Chang HH, Huang JL. Ding Chuan Tang, a Chinese herb decoction, could improve airway hyper-responsiveness in stabilized asthmatic children: a randomized, double-blind clinical trial. Pediatr Allergy Immunol. 2006;17(5):316-22.

[297] Chang TT, Huang CC, Hsu CH. Clinical evaluation of the Chinese herbal medicine formula STA-1 in the treatment of allergic asthma. Phytother Res. 2006;20(5):342-7.

[298] Wen MC, Wei CH, Hu ZQ, Srivastava K, Ko J, Xi ST, et al. Efficacy and tolerability of anti-asthma herbal medicine intervention in adult patients with moderate-severe allergic asthma. J Allergy Clin Immunol. 2005;116(3):517-24. 
[299] Calder PC. n-3 polyunsaturated fatty acids, inflammation, and inflammatory diseases. Am J Clin Nutr. 2006;83(6 Suppl):1505S-19S.

[300] Tapiero H, Ba GN, Couvreur P, Tew KD. Polyunsaturated fatty acids (PUFA) and eicosanoids in human health and pathologies. Biomed Pharmacother. 2002;56(5): 215-22.

[301] Morris MC, Sacks F, Rosner B. Does fish oil lower blood pressure? A meta-analysis of controlled trials. Circulation. 1993;88(2):523-33.

[302] Davidson MH, Stein EA, Bays HE, Maki KC, Doyle RT, Shalwitz RA, et al. Efficacy and tolerability of adding prescription omega-3 fatty acids $4 \mathrm{~g} / \mathrm{d}$ to simvastatin 40 $\mathrm{mg} / \mathrm{d}$ in hypertriglyceridemic patients: an 8-week, randomized, double-blind, placebo-controlled study. Clin Ther. 2007;29(7):1354-67.

[303] Bucher HC, Hengstler P, Schindler C, Meier G. N-3 polyunsaturated fatty acids in coronary heart disease: a meta-analysis of randomized controlled trials. Am J Med. 2002;112(4):298-304.

[304] Iso H, Rexrode KM, Stampfer MJ, Manson JE, Colditz GA, Speizer FE, et al. Intake of fish and omega-3 fatty acids and risk of stroke in women. Jama. 2001;285(3):304-12.

[305] Yaqoob P. Fatty acids as gatekeepers of immune cell regulation. Trends Immunol. 2003;24(12):639-45.

[306] Yaqoob P. Mechanisms underlying the immunomodulatory effects of n-3 PUFA. Proc Nutr Soc.69(3):311-5.

[307] Fortin PR, Lew RA, Liang MH, Wright EA, Beckett LA, Chalmers TC, et al. Validation of a meta-analysis: the effects of fish oil in rheumatoid arthritis. J Clin Epidemiol. 1995;48(11):1379-90.

[308] Park KS, Lim JW, Kim H. Inhibitory mechanism of omega-3 fatty acids in pancreatic inflammation and apoptosis. Ann N Y Acad Sci. 2009;1171:421-7.

[309] Tartibian B, Maleki BH, Abbasi A. Omega-3 fatty acids supplementation attenuates inflammatory markers after eccentric exercise in untrained men. Clin J Sport Med. 21(2):131-7.

[310] Mingam R, Moranis A, Bluthe RM, De Smedt-Peyrusse V, Kelley KW, Guesnet P, et al. Uncoupling of interleukin-6 from its signalling pathway by dietary n-3-polyunsaturated fatty acid deprivation alters sickness behaviour in mice. Eur J Neurosci. 2008;28(9):1877-86.

[311] McMurray DN, Jolly CA, Chapkin RS. Effects of dietary n-3 fatty acids on T cell activation and $\mathrm{T}$ cell receptor-mediated signaling in a murine model. J Infect Dis. 2000;182 Suppl 1:S103-7. 
[312] Gorjao R, Hirabara SM, de Lima TM, Cury-Boaventura MF, Curi R. Regulation of interleukin-2 signaling by fatty acids in human lymphocytes. J Lipid Res. 2007;48(9): 2009-19.

[313] Oddy WH, de Klerk NH, Kendall GE, Mihrshahi S, Peat JK. Ratio of omega-6 to omega-3 fatty acids and childhood asthma. J Asthma. 2004;41(3):319-26.

[314] Peat JK, Mihrshahi S, Kemp AS, Marks GB, Tovey ER, Webb K, et al. Three-year outcomes of dietary fatty acid modification and house dust mite reduction in the Childhood Asthma Prevention Study. J Allergy Clin Immunol. 2004;114(4):807-13.

[315] Laerum BN, Wentzel-Larsen T, Gulsvik A, Omenaas E, Gislason T, Janson C, et al. Relationship of fish and cod oil intake with adult asthma. Clin Exp Allergy. 2007;37(11):1616-23.

[316] Catalli A, MacDonald C, Pundir P, Kulka M. Inhibitory effects of resveratrol on human mast cell degranulation, cytokine, chemokine and leukotriene release. Open J Immunol. (2):187-194. doi:10.4236/oji.2012.24022 